\title{
EFEITO DO HORMÔNIO DO CRESCIMENTO NO SISTEMA LIPOLÍTICO DE BOVINOS: AVALIAÇÃO DA ATIVIDADE DA LIPASE SENSÍVEL A HORMÔNIO E DA CONCENTRAÇÃO DE RNAm DA LIPASE E DA PROTEÍNA G INIBITÓRIA
}

\section{ELAINE PATRICIA MALTEZ DE SOUZA \\ Zootecnista}

Orientador: Prof. Dr. Dante Pazzanese D. Lanna

Dissertação apresentada à Escola Superior de Agricultura “Luiz de Queiroz", Universidade de São Paulo, para obtenção do título de Mestre em Agronomia, Área de Concentração: Ciência Animal e Pastagens

P I R A C I C A B A

Estado de São Paulo - Brasil

Agosto - 2001 


\section{ERRATA}

Autora: Elaine Patricia Maltez de Souza

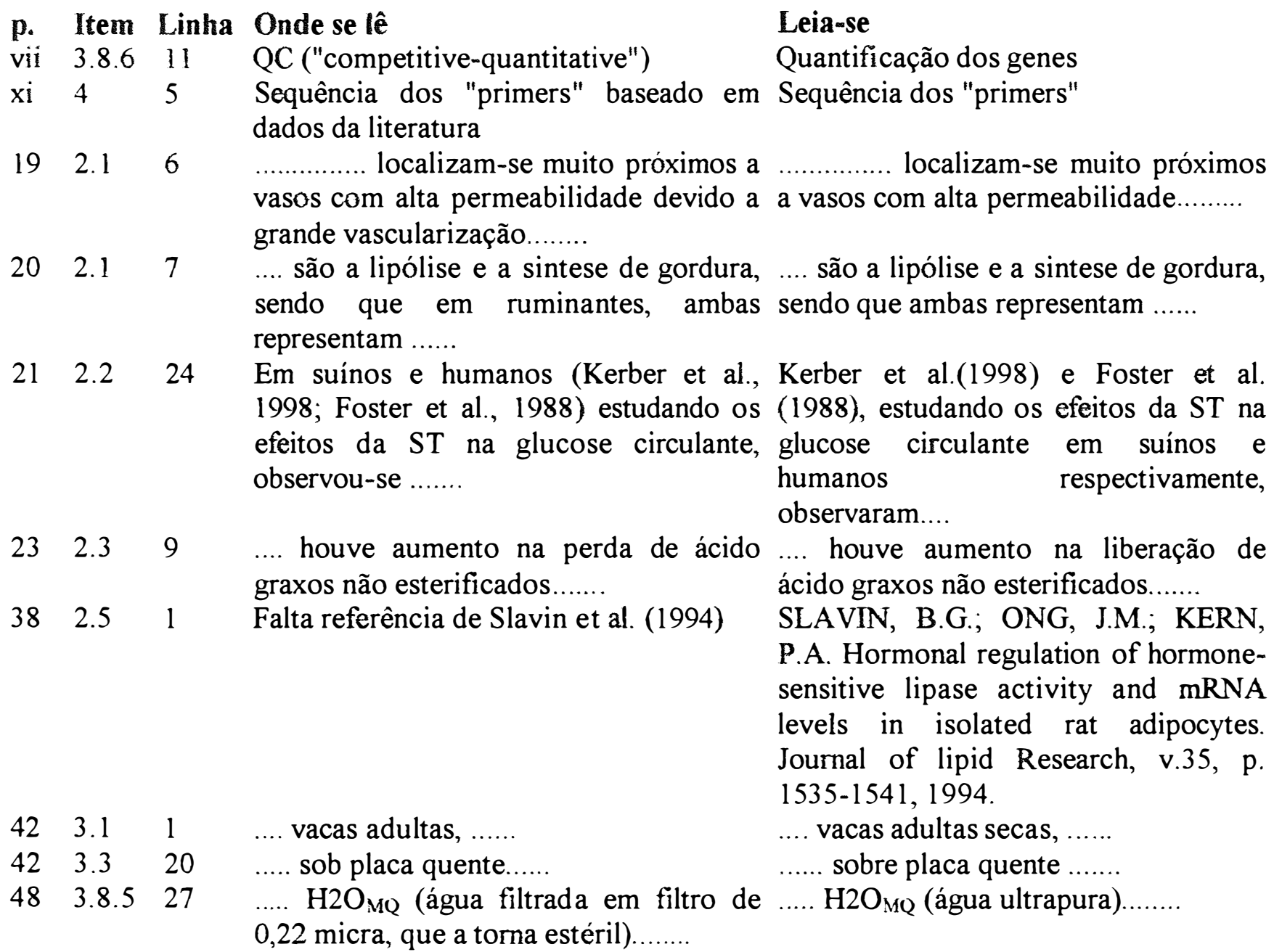

514 Fig. 8 Curva padrão para a proteina Gi 22 na Curva padrão para a proteina Gi 2 na a e $8 \mathrm{~b}$ faixa de $10^{-3}$ fmoles. faixa de $10^{-4}$ fmoles.

564 Fig. Quantidade $\left(\mathrm{x}^{-5} 0^{-5}\right.$ fmoles $)$ da proteína Quantidade $\left(\mathrm{x}_{10^{-4}}\right.$ fmoles $)$ da proteína

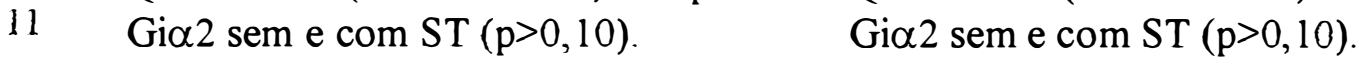

22 Tabela 1. Possíveis mecanismos envolvidos na redução da deposição de gordura e no aumento da lipólise pelo tratamento com somatotropina recombinante.

\begin{tabular}{lllll}
\hline PROCESSO & \multicolumn{3}{l}{$\begin{array}{l}\text { Possiveis cenários do efeito da ST sobre o } \\
\text { metabolismo de lipídios }\end{array}$} \\
\hline Lipogênese & $=$ & $\downarrow$ & $\downarrow$ & $\uparrow$ \\
Lipólise & $\uparrow$ & $=$ & $\uparrow$ & $\uparrow \uparrow$ \\
\hline Deposição líquida & Diminui & Diminui & Diminui & Diminui \\
\hline Lipogênese & $=$ & $\downarrow$ & $\downarrow$ & $\uparrow$ \\
Lipólise & $\uparrow$ & $=$ & $\uparrow$ & $\uparrow \uparrow$ \\
\hline Mobilização líquida & Aumenta & Aumenta & Aumenta & Aumenta \\
\hline
\end{tabular}




$$
\begin{aligned}
& \uparrow \text { aumenta } \\
& \downarrow \text { diminui } \\
& =\text { não há alteração }
\end{aligned}
$$

49 Tabela 5. Faixa de co-amplificação e $n^{\circ}$ de ciclos ideal estimado de cada gene para o PCR

\begin{tabular}{ccc}
\hline Genes & Faixa de co-amplificação & $N^{0}$ de ciclos ideal (antes do platô) \\
\hline HSL & $10^{-5}$ fmoles & 28 \\
Gi 22 & $10^{-4}$ fmoles & 34 \\
Beta actina & $10^{-1}$ fmoles & 23 \\
\hline
\end{tabular}

73 APÊNDICE B: Taxa de lipólise (liberação de ácidos graxos não esterificados) durante cultura crônica de explantes de tecido adiposo de bovinos por 48 horas em meio 199 na presença ou ausência de $b S T(n=5 ; p<0,05)$.

\begin{tabular}{ccc}
\hline & \multicolumn{2}{c}{ Liberação de NEFA (nMol/mg tecido adiposo.h) } \\
\hline & Controle & Com 100ng/ml de bST \\
& $(100 \mathrm{ng} / \mathrm{ml}$ insul. $+10 \mathrm{nM})$ dex $)$ & $(100 \mathrm{ng} / \mathrm{ml}$ insul. $+10 \mathrm{nM})$ dex $)$ \\
Média & $59,0^{\mathrm{a}}$ & $66,0^{\mathrm{b}}$ \\
Desvio Padrão & 4,8 & 3,5 \\
\hline
\end{tabular}


"Se procurar bem, você acaba encontrando

Não a explicação (duvidosa) da vida,

Mas a poesia (inexplicável) da vida"

Carlos Drummond de Andrade

Aos meus pais, Laerte e Teresinha, pelo amor, dedicação e tudo quanto eu possa me lembrar, para que eu realizasse meus sonhos.

À minha família, que sempre abençoou meu caminho.

Ao meu marido, Ricardo, pelo amor, companheirismo, confiança e acima de tudo, compreensão. 


\section{Agradecimentos}

Ao Prof. Dr. Dante Pazzanese Duarte Lanna pela oportunidade e imensa satisfação de trabalharmos juntos, principalmente por todos os seus ensinamentos dentro e fora da sala de aula;

Ao Prof. Dr. Eduardo Francisquine Delgado, pela amizade, atenção e milhares de lições de vida;

À Maria Cristina Cabral, por sua amizade e pelas horas e horas dedicadas para a resolução de problemas "computacionais";

À amiga Fernanda de Paiva Castro, por me ouvir e me incentivar em momentos dificeis;

À Tuka, por organizar e auxiliar em diversos trabalhos e dúvidas do laboratório;

Ao Juliano José de Resende Femandes e Marina Hohaij Carvalho, pela imensa ajuda nas biópsias;

A todas as pessoas que de uma forma ou de outra colaboraram para a realização deste trabalho, sendo através da manifestação de sua amizade ou qualquer outra contribuição;

Aos colegas do Laboratório de Nutrição e Crescimento Animal : Adriana, Alexandre, Amanda, André, Andrea, Dimas, Juliano, Liliane, Luciana, Marcelo, Marco Antônio, Max, Sérgio, pela paciência e ao excelente ambiente de trabalho que eles proporcionaram.

Ao CnPq pela concessão da bolsa. 


\section{SUMÁRIO}

Página

LISTA DE FIGURAS .................................................................................. viii

LISTA DE TABELAS ....................................................................................

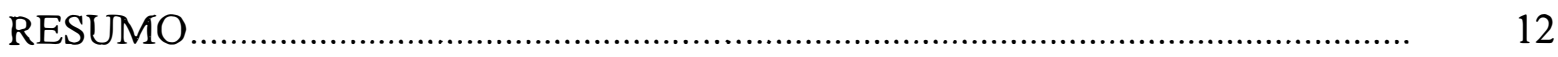

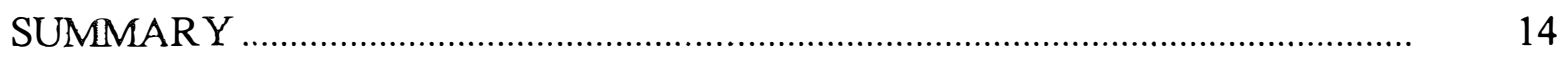

1. INTRODUÇÃ

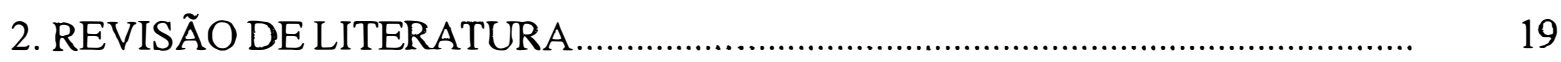

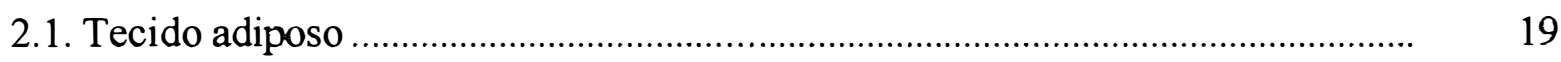

2.2. Somatotropina (ST) e a repartição de nutrientes entre os tecidos ........................... 20

2.3. Efeito da somatotropina no metabolismo do tecido adiposo ................................ 21

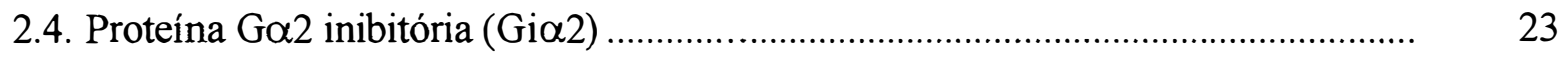

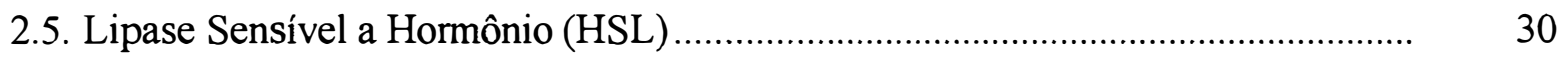

2.6. Somatotropina e a regulação da lipólise ............................................................ 38

2.7. Sistema Somatotropina/ Insulin-Like growth factor (IGF-I) ..............................

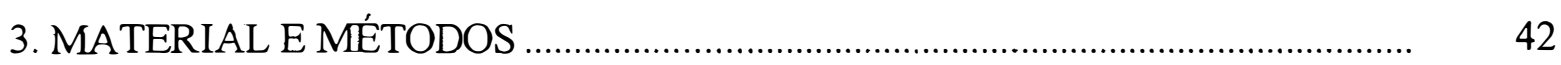

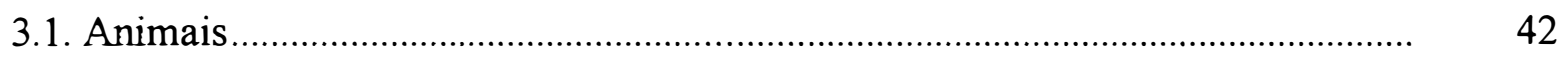

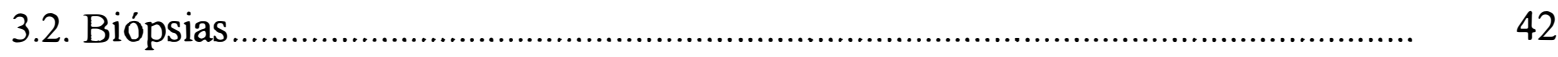

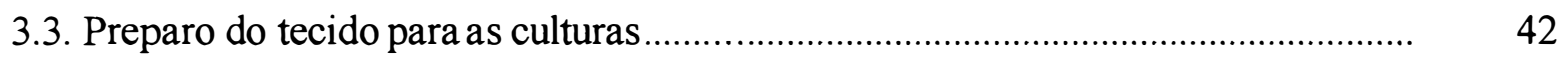

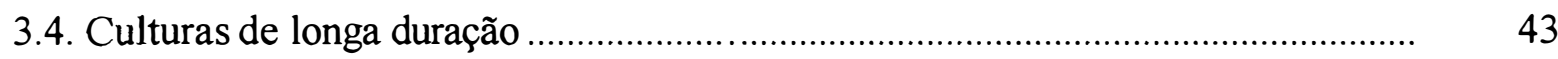

3.5. Ensaio de atividade da Lipase Sensível a Hormônio ............................................

3.6. Avaliação da taxa de lipólise ............................................................................ 44

3.7. Avaliação da expressão da gênica dos genes (abundância de RNAm)................... 
3.7.1 Extração de RNA total .........................................................................................

3.7.2. RT (reação da transcriptase reversa") …………………………………….....

3.8.3. Desenho dos "primers" e construção dos fragmentos .......................................... 45

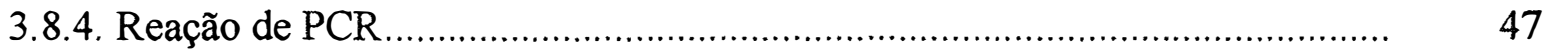

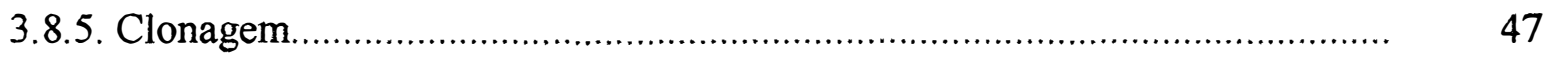

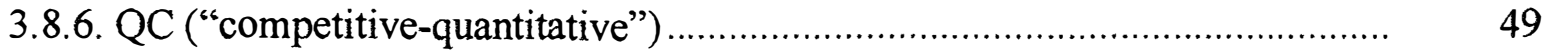

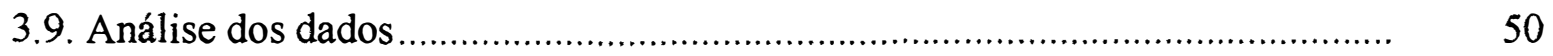

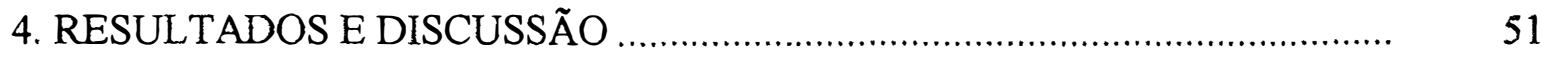

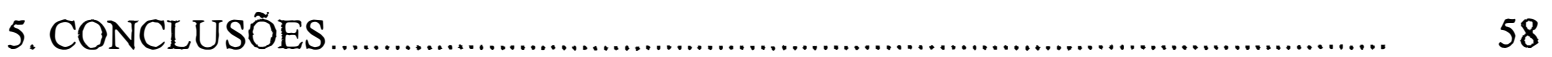

6. REFERÊNCIAS BIBLIOGRÁFICAS ………………….................................... 59

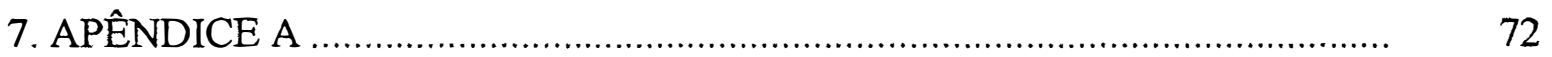

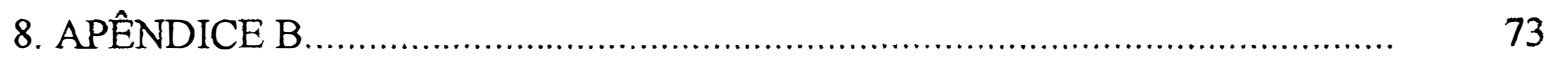




\section{LISTA DE FIGURAS}

Página

1. Ciclo regulatório da proteína $G$

2. Seqüência parcial do RNAm da Gi 2 em Bos taurus

3. Sequência parcial do RNAm da HSL em Bos taurus

4. Organização genômica da HSL humana

5.a. Desenho esquemático da construção dos fragmentos nativo e competidor para aos genes da HSL, Gio2 e beta actina de bovinos

5.b. Exemplo de curva padrão

6.a. Visualização em gel de agarose $3 \%$ corado em brometo de etídeo, da curva padrão do gene da HSL a $10^{-5} \mathrm{fmol}$, comparadas ao marcador de peso molecular (M). Canaletas 1: $25,6 \times 10^{-5} \mathrm{fmol} ; 2: 12,8 \times 10^{-5} \mathrm{fmol} ; 3: 6,4 \times 10^{-5} \mathrm{fmol} ; 4: 3,2 \times$ $10^{-5} \mathrm{fmol} ; 5: 1,6 \times 10^{-5} \mathrm{fmol} ; 6: 0,8 \times 10^{-5} \mathrm{fmol} ; 7: 0,4 \times 10^{-5} \mathrm{fmol} ; 8: 0,2 \times 10^{-5}$ fmol; 9: $0,1 \times 10^{-5} \mathrm{fmol}$.

6.b. Representação gráfica da curva padrão para o gene da HSL na faixa de $10^{-5}$ fmoles. Os valores obtidos das áreas dos picos nativo e competidor, em cada faixa de diluição, foram plotados graficamente em escala logarítmica

7.a. Visualização em gel de agarose $3 \%$ corado em brometo de etídeo, da curva padrão do gene da Gio2 a $10^{-3} \mathrm{fmol}$, comparadas ao marcador de peso molecular (M). Canaletas 1:25,6 × $10^{-3} \mathrm{fmol} ; 2: 12,8 \times 10^{-3} \mathrm{fmol} ; 3: 6,4 \times 10^{-3} \mathrm{fmol} ; 4: 3,2 \times$ $10^{-3} \mathrm{fmol} ; 5: 1,6 \times 10^{-3} \mathrm{fmol} ; 6: 0,8 \times 10^{-3} \mathrm{fmol} ; 7: 0,4 \times 10^{-3} \mathrm{fmol} ; 8: 0,2 \times 10^{-3}$ fmol 
7.b. Representação gráfica da curva padrão para o gene da Gi 2 na faixa de $10^{-3}$ finoles. Os valores obtidos das áreas dos picos nativo e competidor, em cada faixa de diluição, foram plotados graficamente em e scala logarítmica

8.a. Visualização em gel de agarose $3 \%$ corado em brometo de etídeo, da curva padrão do gene da beta actina a $10^{-1} \mathrm{fmol}$, comparadas ao marcador de peso

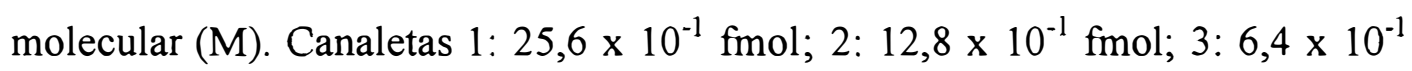
fmol; 4: $3,2 \times 10^{-1} \mathrm{fmol} ; 5: 1,6 \times 10^{-1} \mathrm{fmol} ; 6: 0,8 \times 10^{-1} \mathrm{fmol} ; 7: 0,4 \times 10^{-1} \mathrm{fmol} ; 8$ : $0,2 \times 10^{-1} \mathrm{fmol} ; 9: 0,1 \times 10^{-1} \mathrm{fmol}$;

8.b. Representação gráfica da curva padrão para o gene da beta actina na faixa de $10^{-1}$ fmoles. Os valores obtidos das áreas dos picos nativo e competidor, em cada faixa de diluição, foram plotados graficamente em escala logarítmica

9. Médias ( $\times 10^{-5}$ fmoles) e desvio padrão do gene da HSL dos animais tratados e não tratados com ST (corrigido para o gene da beta actina)

10. Exemplo para um animal da quantificação do RNAm da HSL em tecido adiposo incubado por 48 horas em 1999 (canaletas 1, 2 e 4) e em meio 199 com adição de $100 \mathrm{ng} / \mathrm{ml}$ de bST (canaletas 4,5 e 6 ).

11. Médias ( $\times 10^{-3}$ fmoles) e desvio padrão do gene da Gi 2 dos animais tratados e não tratados com ST (corrigido para o gene da beta actina)

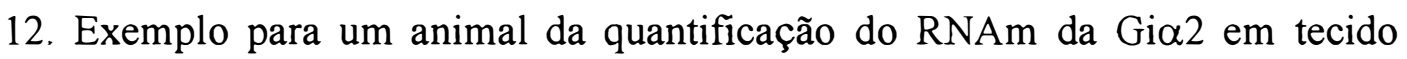
adiposo incubado por 48 horas em 1999 (canaletas 1, 2 e 4) e em meio 199 com adição de $100 \mathrm{ng} / \mathrm{ml}$ de bST (canaletas 4,5 e 6 ).

13. (APÊNDICE A): Visualização de uma biópsia realizada em um dos animais do experimento.

14. (APÊNDICE A): Visualização da preparação dos explantes de tecido adiposo para a cultura de tecidos 
15. (APÊNDICE A): Visualização da estufa de incubação para cultura de tecidos e placas de cultura de tecido com 24 poços 


\section{LISTA DE TABELAS}

Páginas

1. Possíveis mecanismos envolvidos na redução da deposição de gordura e aumento da lipólise pelo tratamento com ST recombinante

2. Mecanismos de transdução de sinal

3. Principais famílias das proteínas $G$

4. Sequência dos "primers" baseados em dados publicados na literatura

5. Faixa de co-amplificação e número de ciclos ideal para cada gene para o PCR

6. Quantificação do RNAm e desvio padrão do gene da beta actina dos animais tratados e não tratados com ST

7. Efeito da ST na atividade da HSL após cultura crônica dos explantes de tecido adiposo por 48 horas em meio 199

8. Quantificação do RNAm e desvio padrão do gene da HSL dos animais tratados e não tratados com ST (corrigidos para o gene da beta actina)

9. Quantificação do RNAm e desvio padrão do gene da Gio2 dos animais tratados e não tratados com ST (corrigidos para o gene da beta actina)

10. (APÊNDICE B): Efeito da ST na lipólise de explantes de tecido adiposo incubado durante 24 horas em meio 199 


\title{
EFEITO DO HORMÔNIO DO CRESCIMENTO NO SISTEMA LIPOLÍTICO DE BOVNOS: AVALIAÇÃO DA ATIVIDADE DA LIPASE SENSÍVEL A HORMÔNIO E DA CONCENTRAÇÃO DE RNAm DA LIPASE E DA PROTEÍNA G INIBITÓRIA
}

\author{
Autora: ELAINE PATRICIA MALTEZ DE SOUZA
}

Orientador: Prof. Dr. Dante Pazzanese D. Lanna

\section{RESUMO}

Diversos sinais atingem as células eucarióticas sendo que alguns necessitam de receptores na membrana para transmitir seus efeitos no interior da célula. As proteínas $\mathrm{G}$ atuam em conjunto com os receptores de membrana, regulando, entre outros processos, a atividade da adenilato ciclase e portanto, os níveis intracelulares de AMP cíclico (AMPc). O aumento do nível de $\mathrm{AMPc}$ ativa a proteína quinase $\mathrm{A}$, responsável pela ativação da lipase sensível a hormônio (HSL) através de fosforilação desta enzima em resíduos de serina. Esta sequência de eventos para ativação da HSL tem papel essencial na regulação da mobilização de ácidos graxos, por regular a atividade catalítica considerada limitante à hidrólise dos triacilgliceróis (TAG) nos adipócitos. O mecanismo através do qual a somatotropina (ST) ou hormônio do crescimento $(\mathrm{GH})$ ativa a lipólise e aumenta a resposta a agonistas betaadrenérgicos, ainda não está completamente elucidado, mas resultados com cultura de tecidos, demonstraram que a ST estimula a lipólise através da via de ativação do AMPc, resultando em maior atividade da HSL, principalmente pela remoção da inibição exercida peła proteína $\mathrm{G}$ inibitória à adenilato ciclase, através de sua subunidade alfa 2. Este estudo 
teve como objetivo principal, verificar o efeito da ST na expressão gênica da HSL e da proteína Gia2, em cultura de tecido adiposo. Seis vacas serviram como fonte de tecido adiposo para as culturas de tecido obtido por biópsia que foram avaliadas para a concentração de RNAm (RNA mensageiro) das proteínas estudadas e a atividade da HSL. Explantes de $30 \mathrm{mg}$ foram incubados durante 48 horas em meio 199 com $25 \mathrm{mM}$ de bicarbonato e $\mathrm{HEPES}\left(\mathrm{pH} 7,4,37^{\circ} \mathrm{C}\right.$ ) e $5 \% \mathrm{CO}_{2}$ nos seguintes tratamentos: 1)Controle: insulina (100 $\mathrm{ng} / \mathrm{ml})$ e dexametasona $(10 \mathrm{nM})$ e 2)Tratamento com bST: insulina (100 $\mathrm{ng} / \mathrm{ml})$, dexametasona (10 $\mathrm{nM})$ e bST (100 ng/ml, ST recombinante bovino - Monsanto). A lipólise foi determinada pela liberação de NEFA no meio de cultura 199 e o RNA total foi extraído dos explantes para quantificação do RNAm da HSL e proteína Gia2. As análises estatísticas foram realizadas usando o teste $\mathfrak{t}$ de Student para amostras pareadas (com ou sem ST) através do programa SAS. Houve um aumento da liberação de NEFA dos homogenatos feitos a partir de tecidos tratados com ST $(19,97$ e $25,37 \mathrm{nMol} / \mathrm{mg}$ proteína.h para os tratamentos controle e com ST, respectivamente; $\mathrm{p}<0,05 ; \mathrm{n}=5$; desvio padrão 1,36 ).

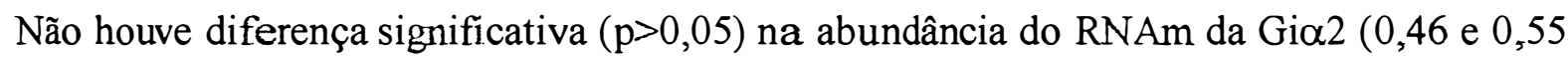
$\times 10^{-3}$ frnol para os tratamentos controle e com ST, respectivamente; $n=5$; desvio padrão 0,25). Embora não tenha sido observado efeito na abundância de RNAm da proteína Gi, a ST alterou a abundância de RNAm da HSL ( $<<0,06 ; 0,08$ e $0,13 \times 10^{-5} \mathrm{fmol}$ para os tratamentos controle e com ST respectivamente; $n=5$; desvio padrão 0,03 ). Os resultados obtidos confirmam a hipótese de que a quantidade da proteína Gi não é alterada, apesar de sugerirem que existe um aumento na abundância de RNAm da HSL, que pode ser responsável por parte do aumento da atividade lipolítica após tratamento com ST. 


\section{EFFECT OF GROWTH HORMONE ON LIPOLYTIC SYSTEM OF BOVINES: ACTIVITY AVALIATION OF HORMONE SENSITIVE LIPASE AND mRNA ABUNDANCE OF LIPASE AND INHIBITORY G PROTEIN}

Author: ELAINE PATRICIA MALTEZ DE SOUZA Adviser: Prof. Dr. Dante Pazzanese D. Lanna

\section{SUMMARY}

Many signals reach the eucaryotic cells and some need surface receptors to transfer its message to the interior of the cell. The G-proteins work with membranes receptors, controling adenylate cyclase activity, and thus cAMP levels. The increase of intracellular levels of cAMP activates protein kinase A, which in turn phosphorylates hormone-sensitive in serine residues. These events play an essencial role in the regulation of fatty acids mobilization, because HSL catalyses the rate-limmiting step to the hidrolysis of triacylglicerol (TAG) in adipocytes. The mechanism(s) involved in somatotropin (ST or growth hormone $\mathrm{GH}$ ), changes in rates of lipolysis and on cell response to $\beta$-adrenergics are not defined. However, tissue cultures datas demonstrated that ST estimulates rates of lipolysis through a relief from the inhibition of G-protein on adenylate cyclase, specifically alfa 2 subunity, wich leads to greater concentrations of cAMP and greater HSL activity. The objective of this work was to study the effect of ST on gene expression of HSL and Gi 
alfa 2 in adipose tissue. Six crossbred cows were used to obtain explants for tissue culture for HSL activity assays and mRNA abundance of HSL and G-proteins. Explants of $30 \mathrm{mg}$ were cultured for 48 hours in medium 199 with sodium bicarbonate $25 \mathrm{mM}$ and HEPES $\left(\mathrm{pH} 7,4 ; 37^{\circ} \mathrm{C}\right)$ and $5 \%$ de $\mathrm{CO}_{2}$, with two treatments: 1) Control: insulin $(100 \mathrm{ng} / \mathrm{ml})$ plus dexametasone (10 $\mathrm{nM})$ and 2) bST: insulin $(100 \mathrm{ng} / \mathrm{ml})$, dexametasone $(10 \mathrm{nM})$, and bST (100 ng/ml, STr-Monsanto). The HSL activity was determined by NEFA release in incubations of homogenate with endogenous lipids and the HSL and Gi2-alfa RNAm concentration determined by QC-RT-PCR using competitive cDNA sequence. The activity of HSL increased on tissues treated with ST (19.97 to $25.37 \mathrm{nMol} / \mathrm{mg}$ protein.h for control and ST treatments; $\mathrm{p}<0.05 ; \mathrm{n}=5$; sd 1.36). There was no differences $(\mathrm{p}>0.05)$ on Gia2 RNAm abundance $\left(0.46\right.$ and $0.55 \times 10^{-3}$ fentomol for control and ST treatments; $n=5$; sd 0.25). ST increase HSL mRNA ( $<<0.06 ; 0.08$ and $0.13 \times 10^{-5}$ fentomol for control and ST treatment- $\mathrm{n}=5$; sd 0.03 ). Results confirm the hypotesis that amount of $\mathrm{Gi}$ is not change by ST. Previus data suggested small increases in HSL activity after ST treatment, results from this experiment confirm that HSL mRNA is increased by ST treatment in vitro. 


\section{INTRODUÇ̃̃O}

Grandes melhoras na eficiência de produção animal serão possíveis a partir da elucidação dos processos metabólicos envolvidos na utilização de nutrientes para crescimento e lactação. A eficiência de crescimento, assim como de produção de leite, estão relacionadas à partição de nutrientes entre deposição de proteína, deposição de gordura e síntese de leite na glândula mamária. Aumentos significativos na eficiência de produção foram obtidos utilizando-se um "repartidor de nutrientes", a somatotropina (ST) ou hormônio do crescimento, em animais em crescimento (Boyd et al., 1989) e em lactação (Bauman et al., 1989).

Apenas com o conhecimento detalhado dos processos físiológicos, envolvidos no controle do uso de nutrientes, surgirão possibilidades de desenvolvimento de estratégias de manipulação do metabolismo animal. Isto é válido tanto na evolução dos tratamentos com hormônios exógenos como para o direcionamento das alterações do genoma de animais domésticos (i.e. animais transgênicos- ver revisão de Li-Na Wei, 1997). Dessa forma, é essencial o estudo dos mecanismos biológicos fundamentais que controlam a utilização de nutrientes pelos tecidos produtivos, como a musculatura esquelética, o tecido adiposo e a glândula mamária.

Durante as últimas décadas, foi inequivocadamente estabelecido que desbalanços entre a ingestão e o gasto de energia por longos períodos, são traduzidos em mudanças nas reservas corporais de lipídios, principalmente na forma de triacilglicerol (TAG) do tecido adiposo branco. Em resposta à demanda energética, os ácidos graxos estocados como TAG podem ser hidrolisados para utilização em outros tecidos (Belgrage, 1985). Esta reação é controlada por uma complexa série de vias sinalizadoras interrelacionadas que resultam na ativação da Lipase Sensível a Hormônio (HSL).

A HSL possui um papel importante na lipólise de ácidos graxos, o maior reservatório de energia dos mamíferos, por catalisar o primeiro e o segundo passos na hidrólise dos TAG (Belfrage, 1985; Langin et al., 1996), liberando glicerol e ácidos graxos não esterificados (NEFA). Seu papel é crítico no controle da homeostase de energia, sendo acentuado em certos estágios físiológicos, como longos períodos de jejum (Frayn et al. 1995; Sztalryd \& Kraemer, 1994), início da lactação e prenhez (McNamara et al., 1987), sendo fundamental para sobrevivência de animais que hibernam (Wilson et al., 1992), em 
pacientes com cancer (Thompson et al., 1993) e obesos (Large et al. 1999; Gasic et al. 1999 ) entre outros.

A lipólise é regulada por mecanismos hormonais e neuronais, particularmente através da ativação enzimática da HSL, que ocorre com a fosforilação reversível da enzima pela proteína quinase A. Agentes que promovem o aumento de AMPc, como as catecolaminas via $\beta$-adrenoreceptores (Nilsson et al., 1980) são responsáveis pela sua ativação, enquanto a insulina, adenosina, prostaglandinas e catecolaminas (no último caso via $\alpha_{2}$ - adrenoreceptores), a inibem principalmente por reduzirem os níveis de AMPc. Os $\beta$-adrenérgicos agonistas se ligam aos receptores na superfície das células, ativando a adenilato ciclase, uma enzima multiregulada capaz de alterar os níveis de AMPc intracelulares (Taussig, 1995; Langin et al., 1996; Gutkind, 1998).

Vários receptores que interagem com o sistema de efetores para modular níveis intracelulares de um segundo mensageiro, parece fazê-lo via intermediários de uma família de proteínas de membrana ligadas a um GTP, denominadas coletivamente de proteínas G. Estas proteínas são capazes de modular a atividade da adenilato ciclase em resposta a interação de ligantes com os receptores $\alpha$ e $\beta$-adrenérgicos. No estado inativo, as proteínas $\mathrm{G}$ formam um complexo heterotrimérico, formado pelas subunidades $\alpha, \beta$ e $\gamma$, com um GDP ligado à subunidade $\alpha$ (Hamm, 1998; Neer, 1995). As classes principais de proteínas $\mathrm{G}$ neste sistema são as $\mathrm{Gs}$ e as Gi, que ativam e inibem a adenilato ciclase, respectivamente.

A mobilização da gordura corporal através do aumento da lipólise, tem sido observada no tratamento de vacas lactantes com somatotropina (ST) ou hormônio do crescimento $(\mathrm{GH})$, sendo função do balanço entre lipólise e lipogênese (Bauman \& Vernon, 1993). Para alguns tratamentos, pesquisadore sugerem que um maior efeito lipolítico das catecolaminas em animais tratados com ST, ocorra através de um aumento na abundância de Gs na membrana (Rodan \& Rodan, 1986), ou alternativamente provoque um defeito funcional na Gi, sem alteração da via de sinalização da Gs (Lanna et al., 1995; Doris et al., 1997; Houseknech \& Bauman, 1997), ou ainda que o tratamento com ST promova a redistribuição da Gi para membranas de baixa densidade, não permitindo o acoplamento com receptores da membrana plasmática (Yip \& Goodman, 1999).

Em vista do papel chave da HSL e Gi no metabolismo do tecido adiposo, observa-se que qualquer variação em sua expressão e função, modulará a extensão da mobilização de 
TAG estocado no adipócito. A regulação aguda através de fosforilação reversível da HSL já foi bem documentada (Belfrage, 1984), mas poucos estudos tem sido devotados a variações na expressão de enzimas envolvidas na via lipolítica na presença de ST.

O objetivo deste trabalho foi ampliar o conhecimento do efeito da ST em bovinos e sobre as enzimas chave para o funcionamento da via lipolítica no tecido adiposo. Para tanto, foram utilizadas técnicas de cultura de tecido já validadas para bovinos (Lanna et al., 1995), em conjunto ao estabelecimento de técnicas de biologia molecular para avaliação da abundância de RNAm da HSL e Gi no tecido adiposo subcutâneo de bovinos. 


\section{REVISÃO DE LITERATURA}

\subsection{Tecido adiposo}

A primeira revisão sobre a físiologia do tecido adiposo data de 1948, quando Wertheimer e Shapiro observaram histologicamente este tecido, concluindo que se tratava de uma densa rede de capilares. Mais tarde, Dole (1956) e Gordom \& Cherker (1956) reconheceram a grande importância fisiológica da liberação de ácidos graxos livres no sangue, para oxidação em outros órgãos.

Os adipócitos localizam-se muito próximos a vasos com alta permeabilidade devido a grande vascularização do tecido adiposo, facilitando o transporte de material do adipócito para a circulação, como por exemplo produtos da lipólise como ácidos graxos livres e glicerol (ver revisão de Rosell \& Belfrage, 1979).

Por volta de 1965 foram descritas técnicas que possibilitaram estudos físiológicos do tecido adiposo (Ho \& Meng, 1964; Oro et al., 1965), desde então, diversos trabalhos tem sido conduzidos em experimentos com animais e humanos, testando hormônios, verificando a eficácia de remédios, no intuito de esclarecer as vias integradas que regulam o seu metabolismo.

O tecido adiposo é considerado um órgão, devido aos seus inúmeros eventos metabólicos e também por produzir hormônios, dentre os quais podemos citar a leptina, o hormônio da "saciedade" (Zhang et al, 1994). O metabolismo do tecido adiposo está intimamente relacionado à atividade adrenérgica, sendo que na maior parte das espécies, a lipólise induzida por catecolaminas é mediada por $\beta$-adrenoreceptores (Lai et al., 1981) e antagonizada pelos $\alpha$-adrenoreceptores (Hittelman et al., 1973; Fain \& Garcia-Sainz, 1983).

Durante a lipólise, o adipócito torna-se progressivamente menor em tamanho e é possível distiguir vesículas pinocitóticas ao longo de toda a célula adiposa (Carpentier et al., 1997), havendo uma proximidade grande destas células a capilares, para facilitar o fluxo de ácidos graxos livres para os demais tecidos, como citado anteriormente (Rosell \& Belfrage, 1979).

Neste contexto, as enzimas responsáveis pela resposta aos receptores agonistas/antagonistas são a proteína G inibitória (Proteína Gi) (ver revisão Neer, 1995) e a 
Lipase Sensível a Hormônio (HSL) (Frayn et al., 1995; ver revisão Langin et al., 1996) que representam as enzimas fundamentais no desencadeamento da lipólise do tecido adiposo. Alguns autores citam as perilipinas (comentaremos detalhadamente no item 2.5) também como proteínas fundamentais no desencadeamento da lipólise (Brasaemle et al., 1999; Clifford et al., 2000; Morimoto et al., 2001), pois a HSL não é capaz de mobilizar as reservas de TAG do adipócito se não ocorrer a ativação das perilipinas.

Os principais eventos metabólicos do tecido adiposo em mamíferos, são a lipólise e a síntese de gordura, sendo que em ruminantes, ambas representam o balanço entre a entrada de nutrientes e os requerimentos calóricos para as funções de produção e crescimento (Bauman, 1976), tendo como ponto principal a ativação/inibição dessas enzimas chave.

\subsection{Somatotropina e a repartição de nutrientes entre os tecidos}

Os processos metabólicos fundamentais ao crescimento e à produção de leite são controlados por uma complexa interação entre uma multiplicidade de hormônios. A somatotropina (ST, ou hormônio do crescimento) parece ter um papel central na utilização de nutrientes (Bauman \& Vernon, 1993).

O aumento no ganho de peso de animais suplementados com ST é conhecido há mais de 60 anos, desde o trabalho pioneiro de Evans e Long (1921), nos EUA, que injetaram ratos com extratos de pituitária bovina. Trabalhos posteriores demonstraram que um fator presente neste extrato também alterava a composição do tecido depositado que continha mais músculo e menos gordura (Lee e Schaffer, 1933). Simultaneamente aos trabalhos de Evans e Long (1921), Stricker e Grueter (1928) e Asdell (1932) observaram que estes extratos aumentavam a produção de leite em ratos e cabras, respectivamente.

Trabalhos detalhados foram conduzidos na Inglaterra, durante a $2^{\mathrm{a}}$ guerra mundial, com o objetivo de aumentar a oferta de alimentos durante o bloqueio nazista. Estes estudos demonstraram que a ST era a proteína presente no extrato descrito por Evans contendo atividade anabólica e lactogênica (Young, 1947). Entretanto, os pesquisadores ingleses logo compreenderam que, mesmo obtendo glândulas pituitárias de todos os animais abatidos no Reino Unido, a quantidade de ST disponível para injeção em animais em produção seria 
suficiente para apenas $2 \%$ do rebanho, com impacto muito reduzido sobre a disponibilidade de alimentos.

O advento da tecnologia do DNA recombinante mudou completamente esta perspectiva, permitindo a obtenção de quantidades ilimitadas de ST. Durante a década de 80, após a publicação do primeiro estudo com ST recombinante (Bauman et al., 1982), um número muito elevado de trabalhos foi conduzido, demonstrando o potencial da ST em alterar as taxas de ganho de peso e a composição dos tecidos depositados (Boyd et al., 1989; Campbell et al., 1991).

A ST é um hormônio protéico com aproximadamente 190 amino ácidos e $22 \mathrm{kDa}$ de peso, sintetizada e secretada pelos somatotrofos localizados na hipófise anterior, sendo sua sequência altamente conservada entre as espécies (de Vos et al., 1992; Tuggle \& Trenkle, 1996). Este hormônio afeta múltiplos tecidos de forma direta e indireta, como no tecido adiposo (Etherton \& Smith, 1991) ou nos músculos (crescimento) e glândula mamária (produção de leite), respectivamente (Radcliff et al., 1997; Mcguire et al., 1998). Seus efeitos metabólicos são amplos, agindo no anabolismo de proteinas, no metabolismo de gorduras e de carboidratos (Radcliff et al., 1997; Etherton \& Smith, 1991; Vernon \& Finley, 1988).

Uma série de estudos bioenergéticos conduzidos na década de 80 demonstrou, inequivocamente, que os efeitos da ST são quase exclusivamente associados ao uso de nutrientes pós-absorção, regulando a "partição de nutrientes" (Bauman et al., 1988; Sechen et al., 1989). O fato da ST não alterar a eficiência dos processos de digestão, absorção e metabolização, é consistente com a revisão de Bauman et al. (1985) demonstrando que a eficiência destes processos é praticamente constante, mesmo entre animais de diferentes raças e com grandes diferenças de mérito genético.

Em suínos e humanos (Kerber et al., 1998; Foster et al., 1988) estudando os efeitos da ST na glucose circulante, observou-se que a sensibilidade à insulina diminuiu em função do tratamento com ST. Sendo uma das propriedades homeostáticas da insulina, a tomada de glucose pelos tecidos como o adiposo e o muscular, o resultado dessa menor incorporação é uma redução principalmente da lipogênese. Botion \& Green (1999) observando cultura primária de adipócitos de ratos tratados com altas concentrações de glucose e insulina, rełataram um aumento nas taxas basais e estimuladas de lipólise, possivelmente devido a altas taxas de sintese de triacilglicerol (TAG) nas células tratadas, aumentando a quantidade de substrato para a atuação de enzimas lipolíticas. 


\subsection{Efeito da ST sobre o metabolismo do tecido adiposo}

A deposição, ou acumulação, de lipídios é função do balanço entre a taxa de síntese e a taxa de mobilização de lipídios (Tabela 1). A maior parte da pesquisa sobre a regulação da síntese de lipídios tem sido feita em ratos (Vernon \& Finley, 1988). Enquanto no rato os lipídios são preferencialmente sintetizados no figado e transportados para o tecido adiposo onde são reesterificados, em animais domésticos há uma variante fundamental, pois o local da síntese de novo dos lipídios é o tecido adiposo, tanto para ruminantes como para suínos (Bauman \& Davis, 1975). Uma outra particularidade do ruminante está nas vias metabólicas utilizadas para geração do NADPH utilizado na síntese de lipídios de novo, o que pode implicar em diferenças nos mecanismos de regulação. Em termos de mobilização de gorduras, o ruminante também difere de espécies de laboratório na magnitude da resposta a hormônios homeostáticos lipolíticos (Yang e Baldwin, 1973; Vernon e Finley, 1988). Estes fatos fazem do modelo experimental do bovino e do suíno algo distinto do rato.

O efeito da ST no metabolismo de lipídios, é um dos principais componentes das alterações na partição de nutrientes e no aumento na eficiência produtiva. Em suínos, a deposição de gordura pode ser reduzida em 80\% (Boyd et al. 1991), enquanto em novilhos essa redução foi de até 65\% (Moseley et al. 1992).

Tabela 1. Possíveis mecanismos envolvidos na redução da deposição de gordura e no aumento da lipólise pelo tratamento com somatotropina recombinante.

\begin{tabular}{|c|c|c|c|c|}
\hline PROCESSO & $\begin{array}{l}\text { Possíveis } \\
\text { metabolis }\end{array}$ & $\begin{array}{l}\text { nários do } \\
\text { de lipídios }\end{array}$ & efeito da & T sobre \\
\hline Lipogênese & $=$ & $\downarrow$ & $\downarrow$ & $\uparrow$ \\
\hline Lipólise & $\uparrow$ & $=$ & $\uparrow$ & $\uparrow \uparrow$ \\
\hline Deposição & Diminui & Diminui & Diminui & Diminui \\
\hline Lipogênese & $=$ & $\downarrow$ & $\downarrow$ & $\uparrow$ \\
\hline Lipólise & $\uparrow$ & $=$ & $\uparrow$ & $\uparrow \uparrow$ \\
\hline Mobilização & Aumenta & Aumenta & Aumenta & Aumenta \\
\hline
\end{tabular}


Em suínos em crescimento (i.e. balanço positivo de energia) $80 \%$ da síntese de gorduras é feita pela via de novo, utilizando glucose como substrato, função de baixa proporção das calorias $(\sim 8 \%)$ da dieta na forma de ácidos graxos pré-formados. Nesta situação cerca de $40 \%$ da utilização de glucose pelo corpo é destinada para a deposição de lipídios, que ocorre no próprio tecido adiposo (Dunshea et al., 1993).

Estudos detalhados desenvolvidos na Universidade de Cornell com tecido adiposo de vacas em lactação, demonstraram diferenças nas respostas em função do estado nutricional dos animais (Bauman et al., 1988; Sechen et al., 1989; Lanna et al., 1995). Em vacas em balanço energético negativo, houve aumento na perda de ácidos graxos não esterificados, indicando um aumento na mobilização de gordura sem alteração nas taxas de síntese. Já nas vacas em balanço energético positivo, a maior parte dos efeitos da ST foi na redução da síntese de gorduras, incluindo reduções nas atividades das enzimas acetil-CoA-carboxilase (ACC) e sintetase de ácidos graxos (FAS) (Lanna et al., 1995).

McNamara e Hillers (1986) demonstraram uma grande redução na taxa de lipogênese in vitro do tecido adiposo, obtido por biópsia de vacas em balanço negativo de energia, sugerindo um efeito da nutrição sobre a lipogênese que poderia ser mediado pelos altos níveis circulantes de ST observados nestes animais (Hove \& Blom, 1973).

Outra possibilidade seria a redução da atividade específica das enzimas, função de alteração nos mecanismos de mensageiros secundários. Lanna et al (1995) demonstraram uma redução de 28 para $11 \%$ no grau de ativação da $\mathrm{ACC}$. Isto parece ter ocorrido por uma inibição da atividade da proteína $\mathrm{G}$ inibitória pela ST, mecanismo inicialmente demonstrado em tecido adiposo bovino (Lanna et al., 1995) e confirmado recentemente por Doris et al. (1996) e Housecknecht et al. (1997). Essa inibição da proteína $G$ inibitória, resulta em maiores níveis de AMPc e aparentemente, menor sensibilidade das células do tecido adiposo à insulina. Esses são exemplos típicos de alterações na resposta a mecanismos homeostáticos que regulam o grau de fosforilação das enzimas limitantes da via lipogênica e lipolítica.

\subsection{Proteína G $\alpha 2$ inibitória}

Centenas de sinais chegam a superficie das células e ligam-se a receptores, entre estes podemos citar hormônios como as catecolaminas, gonadotrofinas, bem como 
substâncias autócrinas e parácrinas como os fatores de crescimento e prostaglandinas entre outros.

As catecolaminas e vários reguladores endócrinos/parácrinos (e.g. adenosina, prostaglandinas) agem através de receptores de membrana (Langin et al., 1996; Gutkind, 1998, Taussig \& Gilman, 1995), modulando a atividade da adenilato ciclase, uma proteína de membrana multiregulada.

Nove isoformas de adenilato ciclase já foram identificadas em mamíferos e possuem peso aproximado de $80 \mathrm{kDa}$ (Sunahara et al., 1996; Cooper et al., 1998). O sistema da adenilato ciclase é composto por vários componentes associados à membrana, entre eles estão os receptores de neurotransmissores e as proteínas $G$, que são ativadoras potenciais da maioria das isoformas da adenilato ciclase (Tesmer et al., 1997; Yan et al., 1997; Zimmerman et al., 1998). Estas proteínas servem como intermediários entre o receptor e proteínas efetoras em vários processos de sinalização transmembrana (Gilman, 1987; ver revisão de Evora \& Nobre, 1999).

Rodbell et al. (1971) estudando a habilidade do glucagônio em estimular a adenilato ciclase em hepatócitos, especularam sobre a presença de mais de um componente na ativação da adenilato ciclase, após descobrir o envolvimento da guanosina trifosfato (GTP). Gilman et al. (1987), descobriram um fator de membrana diferente de um receptor ou da adenilato ciclase, levando à identificação deste elemento, posteriormente sendo descrita como uma grande família de proteínas, denominada de proteínas $\mathrm{G}$.

Nos anos 70, diversos trabalhos demonstraram a influência de hormônios na atividade da adenilato ciclase através de um sistema dependente de GTP (Pohl et al., 1970; Rodbell et al., 1971; Londos et al., 1974; Yamamura et al., 1977).

O mecanismo pelo qual um sinal bioquímico é gerado a partir de um hormônio ou um neurotransmissor é genericamente chamado de transdução de sinal (ver revisão Rodbell, 1985) e pode ocorrer através de receptores intracelulares ou de receptores presentes na superfície celular (Tabela 2). Neste último caso os receptores podem estar acoplados a efetores intracelulares como as proteínas $\mathrm{G}$.

O sistema de receptores intracelulares e da superfície da célula podem estar ligados diretamente ao processo de expressão gênica, necessitando de tempo para a transcrição e posterior tradução do RNAm, ou o processo se dá através de um mecanismo sofisticado o 
qual podem participar tanto AMPc quanto GMPc, podendo regular, também, a expressão de determinados genes (Evora \& Nobre, 1999).

Receptores relacionados a mensageiros secundários funcionam como verdadeiros amplificadores de sinal, pelo fato de uma molécula do receptor ativar várias moléculas responsáveis pelos efeitos intracelulares (Rodbell, 1985).

\begin{tabular}{|l|}
\hline \multicolumn{1}{|c|}{ Tabela 2 - Mecanismos de transdução de sinal } \\
\hline $\begin{array}{l}\text { 1) } \text { Receptores intracelulares: receptores esteróides, receptores da vitamina D, receptores de ácido } \\
\text { retinóico e receptores da tiroxina. }\end{array}$ \\
\hline 2) Receptores de membrana diretamente acoplados a moléculas efetoras. \\
\hline 3) Receptores ligados a canais iônicos: receptores ni cotínicos, colinérgicos, receptores GABA. \\
\hline 4) Receptores com atividade catalítica: receptores da insulina. \\
\hline 5) Receptores de membrana acoplados a moléculas efetoras através de mensageiros secundários. \\
\hline 6) Receptores acoplados à adenilato ciclase: receptores e adrenérgicos, glucagônio e epinefrina. \\
\hline $\begin{array}{l}\text { 7) Receptores acoplados ao ciclo fosfatidilinositol e ao diacilglicerol: receptores muscarínicos, receptores } \\
\text { 1 e fatores de crescimento }\end{array}$ \\
\hline Fonte : Evora \& Nobre 1999
\end{tabular}

As proteínas $G$ correspondem a uma super família de proteínas com a capacidade de se ligar ao GDP/GTP (Tabela 3), compostas de três polipeptídeos: uma subunidade $\alpha$ (alfa) capaz de se ligar e hidrolisar GTP (guanina trifosfato), uma subunidade $\beta$ (beta) e uma $\gamma$ (gama).

\begin{tabular}{|l|}
\hline \multicolumn{1}{|c|}{ Tabela 3 - Principais famílias das proteínas G } \\
\hline $\begin{array}{l}\text { 1) Gs estimulam a adenilato ciclase através de receptores beta adrenérgicos e aumentam a condutância } \\
\text { do cálcio no coração. }\end{array}$ \\
\hline $\begin{array}{l}\text { 2) Gi - parecem ter múltiplas formas de inibir a adenilato ciclase através de receptores alfa } 2 \\
\text { adrenérgicos. }\end{array}$ \\
\hline 3) Gt - também conhecida como transducina liga o fotorreceptor rodopsina na retina. \\
\hline 4) Go - podem regular canais de cálcio. \\
\hline 5) Gk - regulam os canais de potássio. \\
\hline 6) Gp - ainda não estão bem definidas, mas parece que podem regular fosfolipases \\
\hline
\end{tabular}
Fonte: Evora \& Nobre, 1999 
O tamanho das subunidades $\alpha$ varia entre 39 e $54 \mathrm{kDa}$ e estas proteínas contém regiões altamente conservadas em suas estruturas primárias (Lochrie \& Simon, 1988). Ao contrário das subunidades $\alpha$, apenas duas subunidades $\beta$ são conhecidas com massa variando entre 35 e $36 \mathrm{kDa}$ com mais de $90 \%$ da seqüência de aminoácidos idêntica (Amatruda et al., 1988). Das subunidades $\gamma$, sabe-se apenas que são pequenas (aproximadamente $8 \mathrm{kDa}$ ), pois poucos membros foram sequenciados (Roof et al., 1985; Evans et al., 1987).

A função das proteínas $\mathrm{G}$ é acoplar receptores ativados por agonistas ao sistema de efetores que altera as concentrações intracelulares de um segundo mensageiro. Para isso, em algumas células, a proteína $G$ regula a atividade da adenilato ciclase (Taussig \& Gilman, 1995; Neer, 1995), sendo sua subunidade $\alpha$ a responsável pela ativação (Gs) ou inibição (Gi) desse sistema.

Quando o GDP está ligado, a subunidade $\alpha$ está associada às subunidades $\beta \gamma \mathrm{e}$ forma um heterotrímero inativo. Assim que a célula recebe um sinal químico ou físico, que estimule o receptor, há uma mudança conformacional do heterotrímero. Essa mudança leva à perda de afinidade da ligação GDP pela subunidade $\alpha$, que se desliga da mesma. Como a quantidade de GTP na célula é maior que a de GDP, rapidamente seu lugar é ocupado por um GTP (ver revisão Neer, 1995; Susa, 1999).

Fatores antilipolíticos como a adenosina e a prostaglandina E, interagem com seus receptores específicos na superfície da célula e isto resulta na dissociação e ativação de isoformas das proteínas heterotriméricas inibitórias ligadas ao GTP (Gi) em subunidade $\alpha$ e subunidade $\beta$ e $\gamma$ (Bimbaumer et al. 1990), provocando a dissociação de $\alpha$ do complexo $\beta \gamma$ iniciando a via de sinalização. O estado ativado permanece até o GTP ser hidrolisado em GDP pela atividade intrínseca GTPase da subunidade $\alpha$ (Carty et al., 1990; Linder et al., 1990), reassociando novamente as três subunidades e retornando ao receptor em seu estado inativo (Figura 1). 


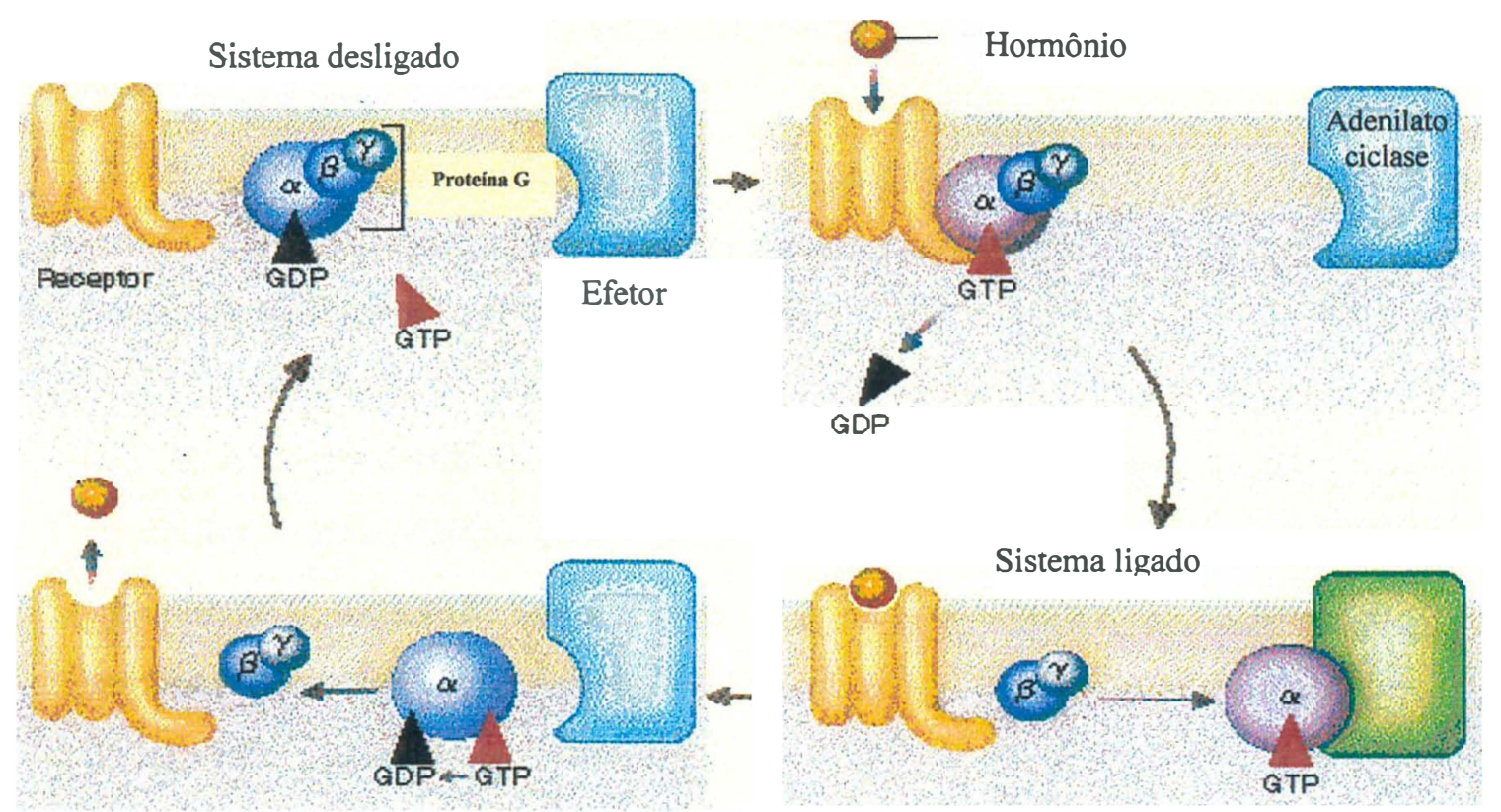

Figura 1. Ciclo regulatório da proteína G (fonte: Susa, 1999)

Três isoformas de Gi foram identificadas, todas com diferentes subunidades $\alpha$

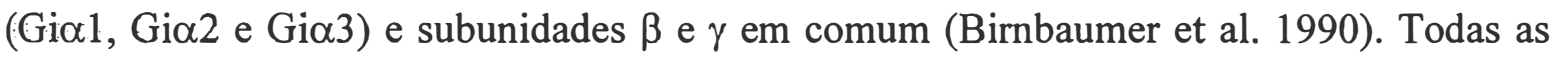
três isoformas estão presentes no tecido adiposo (Mitchell et al., 1989), mas a Gia2 parece ser a forma envolvida na transmissão do sinal inibitório do receptor da adenosina (A1) para

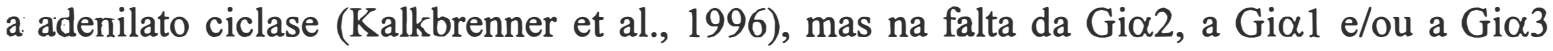
também podem transmitir o sinal do receptor da adenosina (Rudolph et al., 1996).

Foi observado in vitro, a fosforilação da subunidade $\alpha$ em resíduos de serina pelo receptor da insulina (Lounsbury et al., 1991), embora mudanças em sua atividade tenham sido modestas. Talvez a fosforilação altere a especificidade com que este efetor se liga ao receptor, pois na maioria dos casos a fosforilação não altera a atividade da proteína, mas poderia alterar a sua localização ou associação com outras proteínas (Koch et al., 1991), adquirindo um papel importante no complexo regulatório neste sistema.

Todas as subunidades $\alpha$ das proteínas $\mathrm{G}$ possuem uma ligação covalente no $\mathrm{N}$ terminal, com ácidos graxos saturados e os mais comuns são o miristato e palmitato (ver revisões Wedegaertner et al., 1995; Hamm, 1998; Neer, 1995). A N-miristolação, é o resultado de uma adição pós - traducional permanente deste ácido graxo saturado de 14 carbonos, a um resíduo de glicina no $\mathrm{N}$-terminal após a remoção da metionina inicial. Todas as subunidades $\alpha$ das proteínas $\mathrm{G}$ (com exceção da $\alpha_{\mathrm{t}}$ ) contém também o palmitato 
(ácido graxo saturado com 16 carbonos), ligado por uma ligação tioéster (portanto pode ser transitória) a uma cisteína próximo ao $\mathrm{N}$-terminal, mas a bioquímica da palmitolação ainda não está bem estudada. Embora trabalhos com relação a estas modificações por ácidos graxos sejam escassos, alguns dados sugerem que ao prevenir a miristolação, previne-se também a palmitolação (Hallac et al., 1993).

A prenilação é uma modificação covalente que ocorre na subunidade $\gamma$ da proteína

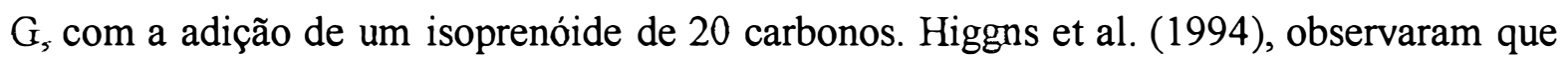
ao perder 3 aminoácidos do C-terminal, a subunidade $\gamma$ foi incapaz de interagir com a subunidade $\beta$, indicando que a prenilação é necessária para a formação do complexo $\beta \gamma, \mathrm{e}$ portanto, para a atividade da proteína (Myung et al., 1999). Estas modificações por lipídios podem estar associadas a ancoragem em membranas celulares, principalmente devido à sua hidrofobocidade, que contribui para uma forte associação com membranas (Wedegaertner et al., 1993). Ainda não foi identificada nenhuma modificação lipídica na subunidade $\beta$.

A especificidade deste sistema poderia ser resumida assim: cada tipo de receptor interage com uma única proteína $G$, no entanto, isto não ocorre, pois existem mais receptores que proteínas $G$. Portanto, a especificidade para as proteinas $G$ depende não somente da presença da seqüência de reconhecimento correta da proteína $G$, mas também de um controle apropriado de outras regiões citoplasmáticas (Wong \& Ross, 1994).

Asano et al. (1984), observaram que receptores $\beta$-adrenérgicos podem ativar ambas proteínas Gi e a Gs, mas dependendo do tipo de célula em que se localiza, ocorre uma predominância de uma ativação sobre a outra, levando a respostas celulares diferentes. Em vesículas fosfolipídicas reconstituídas, ativa de 2 a 3 vezes mais $\mathrm{Gs}$ que $\mathrm{Gi}$, já em células cardíacas, mais Gi que Gs (Cerione et al., 1986). Ainda, a liberação do complexo $\beta \gamma$ tanto da Gs quanto da $\mathrm{Gi}$, pode ativar efetores igualmente, sendo portanto muito importante na resposta final celular a qualquer estímulo externo.

As subunidades $\alpha$ hidrolisam GTP a diferentes taxas (Carty et al., 1990; Linder et al., 1990), proporcionando uma meia vida diferente para cada subunidade. Enquanto um sinal pode ser rapidamente extinguido outro pode sustentar-se por mais tempo e permanecer predominante. Essas diferenças podem ser moduladas por proteínas intracelulares e também por alguns efetores, que são elementos importantes de especificidade. Tanto a fosfolipase C (PLC) quanto a GMPc fosfodiesterase (guanina monofosfato cíclica 
fosfodiesterase) são efetores importantes pois podem aumentar a atividade GTPase das proteínas G ativadas (Arshavsky \& Bownds, 1992).

O sequenciamento parcial do DNAc (DNA complementar) de algumas proteínas Gi, já foi concluído para várias espécies, entre elas, bovinos (Nukada et al., 1986; Delgado et al., 2001- Figura 2/ nº de acesso no Genbank: AF354744) e humanos (Beals et al., 1987).

O gene da Gia2, descrito por Itoh et al. (1988) em humanos, é composto de 8 exons e 7 íntrons e muito semelhante à seqüência de aminoácidos de outros membros da família, como por exemplo Gia3.

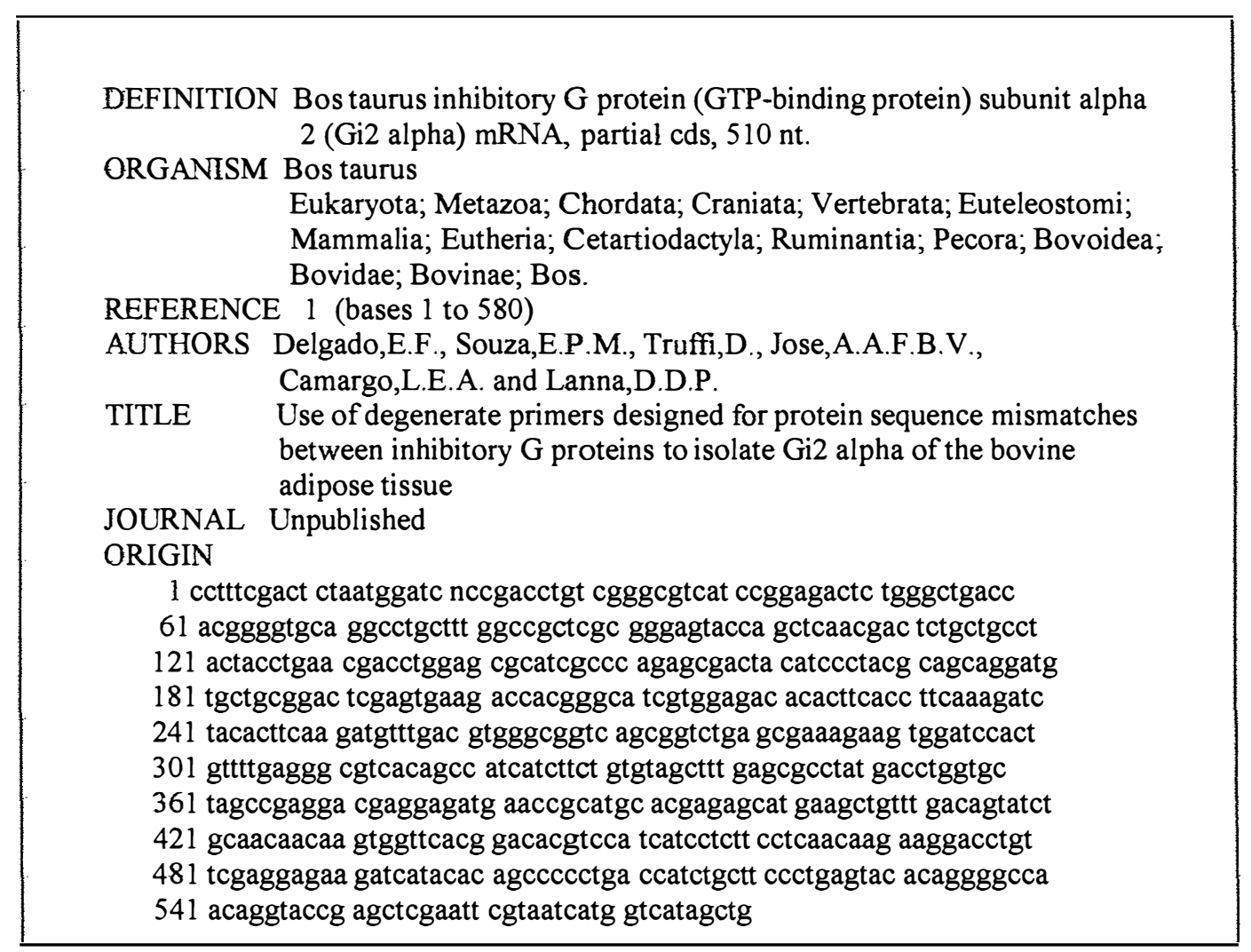

Figura 2: Seqüência parcial do RNAm da Gi $\alpha 2$ em Bos taurus ( $n^{\circ}$ de acesso no Genbank: AF354744).

A proteína Gi pode atenuar os efeitos dos hormônios lipolíticos, por ação direta da sua subunidade $\alpha$, ou liberando sua subunidade $\beta$ (Birnbaumer et al., 1990), sendo a atividade da adenilato ciclase regulada por mecanismos balanceados entre as proteínas Gs e Gi. 
Alguns trabalhos não demonstram nenhuma alteração na atividade da proteína $\mathrm{G}$ em tratamento com hormônios (Roupas et al., 1991), devido principalmente a grande quantidade de Gi se associando seletivamente a membranas de baixa densidade no tratamento com ST e dexametasona, sugerindo uma mudança na distribuição da proteína $G$ em tratamento com hormônios. Já Rodan \& Rodan (1986), utilizando tratamento com dexametasona em células da linhagem ROS 17/2.8, observaram um aumento nos receptores $\beta$-adrenérgicos e na abundância da proteína Gs.

Adipócitos de ratos Zucker (ratos que sofrem de obesidade genética pós desmama, hiperglicemia, resistência a insulina e hipotireoidismo) obesos e normais, não apresentaram diferenças nos níveis de Gia.2, sendo que nos animais normais houve uma diferença na função da Gi. Por outro lado, as membranas das células dos animais obesos apresentaram metade do número de receptores $\beta$-adrenérgicos e uma queda na quantidade da Gs (Strassheim et al., 1991). Isto sugere que a ativação atenuada da adenilato ciclase pode contribuir para a menor resposta lipolítica nos animais obesos. Já em ovinos e bovinos, a menor funcionalidade da proteína Gi 2 tem sido apontada como causa da maior lipólise no tecido adiposo de animais recebendo tratamento com ST (Lanna et al., 1995; Doris et al., 1997; Houseknecht \& Bauman, 1997).

Em animais em balanço negativo de energia, o tratamento com ST promove um aumento da mobilização da gordura corporal e o mecanismo envolvido na estimulação da lipólise parece envolver a via de ativação do AMPc, principalmente pela remoção da inibição da proteína Gi à adenilato ciclase (Lanna et al., 1995; Doris et al., 1996; Lanna \& Bauman, 1999; Yip \& Goodman, 1999).

\subsection{Lipase Sensível a Hormônio (HSL)}

A HSL é distinguida de todas as outras lipases devido a sua atividade ser controlada através de fosforilação/defosforilação. Um resíduo simples de serina (sítio regulatório) é fosforilado pelo AMPc- PKA (proteína quinase A dependente de adenosina monofosfato cíclico), onde $1 \mathrm{~mol}$ de fosfato é incorporado por mol de subunidade (Stralfors \& Belfrage, 1983). Apesar do controle exercido pela fosforilação reversível do sítio regulatório sobre o estado ativo da enzima, a atividade da HSL purificada é aumentada de 2 a 3 vezes quando é fosforilada pelo AMPc-PK in vitro (Vaughan et al., 1963), mas chega a aumentar em até 50 
vezes, quando a ativação ocorre através de estimulação por hormônios lipolíticos em céłulas adiposas isoladas de ratos (Fredrikson et al., 1981), causando um aumento significativo na taxa de lipólise (Stralfors \& Belgrage, 1983).

Células adiposas, incorporam $\mathrm{P}^{32}$ em um segundo sítio de fosforilação, chamado sítio basal (Stralfors \& Belgrage, 1983; Garton et al., 1988), que não altera as taxas de lipólise (Stralfors et al., 1984), já o sítio responsável pelo aumento da atividade da HSL, denominado de sítio regulatório, parece responder somente a estimuladores da adenilato ciclase (Olsson \& Belfrage, 1988).

Anteriormente foi demonstrado que a fosforilação do sítio basal não é pré - requisito para a fosforilação do sítio regulatório in vitro (Olsson et al., 1986) e a desfosforilação do sítio regulatório não é afetada pelo estado de fosforilação do sítio basal (Olsson et al., 1988), embora Garton et al., (1989) tenham sugerido um possível papel antilipolítico para a fosforilação do sítio basal, já que não afeta diretamente a atividade da enzima, mas pode prevenir a fosforilação do sítio regulatório, pois o sítio basal pode servir como um sítio de reconhecimento ou ainda afetar a conformação da molécula, aumentando ou reduzindo sua disponibilidade para a fosforilação. Hipótese consistente com o trabalho de Garton et al.(1988), que identificaram que estes dois sítios localizam-se muito próximos um do outro.

Butcher \& Baird (1968) demonstraram que epinefrina e dibutiril AMPc podem ativar a HSL em tecido adiposo, e a purificação da enzima confirmou que a HSL é ativada pela fosforilação reversível em dois aminoácidos distintos (Belfrage, 1984).

A mobilização de TAG do tecido adiposo, ou lipólise, é o resultado líquido do balanço entre agentes lipolíticos e antilipolíticos que atuam na atividade da adenilato ciclase, sendo a lipólise influenciada pelo quanto a célula foi estimulada e pelo balanço entre as concentrações de agentes (hormônios) lipolíticos e antilipolíticos (Honnor et al., 1984).

Situações que induzem o aumento de AMPc (ver revisão Hardie \& MAcKintosh, 1992; Honnor et al., 1984) resultam em maior liberação de ácidos graxos e glicerol. Dentre estas podemos citar o estresse celular, jejum prolongado em humanos (Amer et al., 1981) e ruminantes (Frohli \& Blum, 1988), durante exercícios físicos (Amer et al., 1990; Wahrenberg et al., 1991) e pela liberação de citoquinas em resposta a agentes infecciosos (ex. fator de necrose de tumor alfa -TNF- $\alpha$; Patton et al., 1986). Nestas condições se observa fosforilação e ativação da HSL. 
Wahrenberg et al. (1991), estudando os efeitos dos exercícios em humanos saudáveis, observou que o aumento na resposta $\beta$-adrenérgica induzida pelo exercício, pode ser semelhante a agentes que atuam sobre a adenilato ciclase, proteína $G$, fosfodiesterase e proteína quinase, visto que envolve adaptações no nível da HSL.

O metabolismo do tecido adiposo é regulado diferentemente em função de sua localização, sendo os principais responsáveis pelas diferenças regionais na lipólise, o número de $\beta$-adrenoreceptores e o sexo (Wahrenberg, 1991). A lipólise estimulada por catecolaminas (em exercício físico), varia em função da localização das células adiposas, observadas in vitro e in vivo, (Wahrenberg et al., 1991), demonstrando a adaptabilidade a lipólise na região abdominal, mais em mulheres que em homens, e da região glútea mais em homens do que em mulheres.

A insulina também apresenta uma ação diferenciada dependente da região de atuação, apresentando maiores efeitos antilipolítcos em células adiposas do abdômen do que em células adiposas femorais (Rebuffé-Scrive et al., 1987). A influência da obesidade indica alguma diferença do tipo de distribuição da gordura corporal na taxa de lipólise regional (Kissebah et al., 1982) e do número reduzido, em relação a pessoas normais, de receptores $\beta$-adrenérgicos, observado em crianças obesas, por Bougnéres et al. (1997).

A HSL pode ser encontrada nos diversos tecidos dos mamíferos, sendo hormonalmente ativável e sua função dependente de sua localização (Holm et al., 1987). As adrenais, os ovários, o coração e o músculo esquelético possuem uma espécie de HSL antigenicamente e enzimologicamente muito semelhante àquela encontrada no tecido adiposo, mas não foi encontrada nos rins e figado. A maior parte da HSL encontra-se no tecido adiposo ( $>80 \%$ ), os outros órgãos contribuem com menos de $1 \%$, exceto testículos (aproximadamente 4\%) e músculo esquelético (devido à sua grande massa, 15\%)(Holm et al., 1987).

Sua presença nas adrenais e ovários sugere uma possível atuação na esteroidogênese (Kraemer et al., 1991; Hui, 1996). A HSL também é expressa nos testículos, incluindo espermátides, sugerindo seu envolvimento no desenvolvimento ou função do espermatozóide (Holst et al., 1994; Holst et al., 1996).

A hidrólise de colesterol ester em células esteroidogênicas pela colesterol ester hidrolase também é estimulada pelo AMPc assim como a HSL, por isso especulava-se que a atividade da colesterol ester hidrolase e da HSL eram catalisadas por enzimas similares ou 
pelas mesmas enzimas (Yeaman, 1990; Kraemer et al., 1991). Esta visão, foi recentemente comprovada usando a eliminação (knockout) do gene da HSL em camundongos, através de recombinação homóloga em células tronco embrionárias (Osuga et al., 2000). Testículos, tecido adiposo branco e marrom perderam a atividade da colesterol ester hidrolase, e não ocorreu mais a hidrólise de triacilgliceróis, embora já tenha sido demonstrado que a HSL é capaz de degradar esta classe de lipídios, e os machos homozigotos mutantes para o alelo da HSL, eram estéreis devido à oligoespermia (número reduzido de espermatozóides).

Várias desordens do metabolismo do tecido adiposo, entre elas o diabetes mellitus (Kahn, 1992), obesidade (Reynisdottir et al., 1994; Bougnéres et al., 1997), distrofia miotonica (Brook et al., 1992) e hipertermia maligna (Levitt et al., 1995; Fujii et al., 1991), podem estar relacionadas à via de ativação da HSL, principalmente pelo possível envolvimento do aumento da função de $\alpha$-adrenoreceptores (Reynisdottir et al., 1994) ou de $\beta$-adrenoreceptores (Rodan \& Rodan, 1985; Lai et al., 1982), apesar de no diabetes mellitus e obesidade, vários genes estejam envolvidos.

Large et al. (1999), reportaram uma diminuição na abundância do RNAm (RNA mensageiro), na quantidade da proteína e atividade da HSL em humanos obesos, sendo que isto poderia explicar, pelo menos em parte, a menor atividade da enzima.

No caso da hipertermia maligna, que afeta tanto humanos (Levitt et al., 1995) quanto suínos (Fujii et al., 1991) podendo levar à morte ambos, e principalmente diminuindo o valor comercial da carne de suínos, demonstram que a localização dos genes do receptor da rianodina e da HSL estão muito próximos nos cromossomos (Gu et al., 1992), por isso o interesse em estudar se o gene da HSL pode estar ligado, ou pode contribuir para os sintomas da hipertermia maligna.

Langford et al., (1999), reportaram que a HSL está presente em mais alta concentração em musculatura oxidativa que glicolítica, e é estimulada pela adrenalina via $\beta$-adrenoreceptores e pela contração muscular (Langford et al., 2000), sendo fosforilada em paralelo com a glicogênio fosforilase, permitindo o recrutamento simultâneo de todas as reservas intra e extra musculares de energia.

O DNAc da HSL foi obtido do tecido adiposo de ratos e humanos (Holm et al., 1988; Langin et al., 1993), os quais apresentaram $82 \%$ de homologia entre si. Em bovinos, somente a seqüência parcial do RNAm foi obtida, com 429 pares de bases sequenciados 
(Figura 3). O gene da HSL foi localizado no cromossomo 19, braço q em suínos por Gu et at (1992).

Não foram encontradas similaridades entre a HSL e outras lipases, mas uma homologia inesperada com 5 enzimas de procariotos (Langin \& Holm, 1993) e com a lipase 2 de Maraxella TA144, uma bactéria antártica (Langin et al., 1993), revela uma possível adaptação evolucionária para certos animais, quando a mobilização de lipídios é crítica para a sobrevivência em condições de baixas temperaturas (ex. pecilotermos e hibernantes).

Em marmotas (Marmota flaviventris), houve um aumento na abundância de RNAm do gene da lipoproteína lipase (enzima limitante na extração de ácidos graxos dos quilomícrons e lipoproteínas de baixa densidade circulantes, para estocar nos adipócitos), durante o período de ganho de peso e um aumento do RNAm da HSL durante a fase de jejum (hibernação), período em que os lipídios estão sendo mobilizados (Wilson et al., 1992).

\begin{tabular}{|c|c|}
\hline $\begin{array}{l}\text { AUTHORS } \\
\text { TITLE } \\
\text { JOURNAL } \\
\text { REFERENCE } \\
\text { JOURNAL }\end{array}$ & $\begin{array}{l}\text { Lee,B.K. and Crooker,B.A. } \\
\text { Partial sequence and polymorphisms in the bovine hormone } \\
\text { sensitive lipase (bHSL) gene } \\
\text { Unpublished } \\
\text { (bases } 1 \text { to } 429 \text { ) } \\
\text { Submitted (13-NOV-1996) Animal Science, University of } \\
\text { Minnesota, } \\
1364 \text { Eckles Ave, St. Paul, MN 55108, USA }\end{array}$ \\
\hline $\begin{array}{l}\text { ORIGIN } \\
1 \text { gccttgac } \\
61 \text { gacctgg } \\
121 \text { gagacac } \\
181 \text { tctgaaat } \\
241 \text { gccgcct } \\
301 \text { ctctactc } \\
361 \text { atgttgg } \\
421 \text { gactcgt }\end{array}$ & $\begin{array}{l}\text { ggtcggccgg tcaactggga accgactccc tcaaaagcct gaagctgaat } \\
\text { cc tcaggaacag aagtgacaca acagacacgc cagagttgtc actgtccgcg } \\
\text { tcg gccctccgt accctcaacc atcaacttct tacttggatc tgaggatgga } \\
\text { gt ctgaggcccc agaggagctg aacaacaagg accgagttcg aggtgtgggc } \\
\text { cc ccgagggtt ccacccacg g cgctgtagcc agggtgccat gtggatgccc } \\
\text { gg cccccatcgt caagaatccc ttcatgtcac cgctgctggc acccaacagc } \\
\text { ga ctctgccacc tgtgcacatc gtggcctgcg cgctggaccc catgctggac } \\
\text { t }\end{array}$ \\
\hline
\end{tabular}

Figura 3: Seqüência parcial do RNAm da HSL em Bos taurus.

O gene da HSL humana é composto por nove exons e codifica uma proteína de 775 aminoácidos (Langin et al., 1993) (Figura 4). 


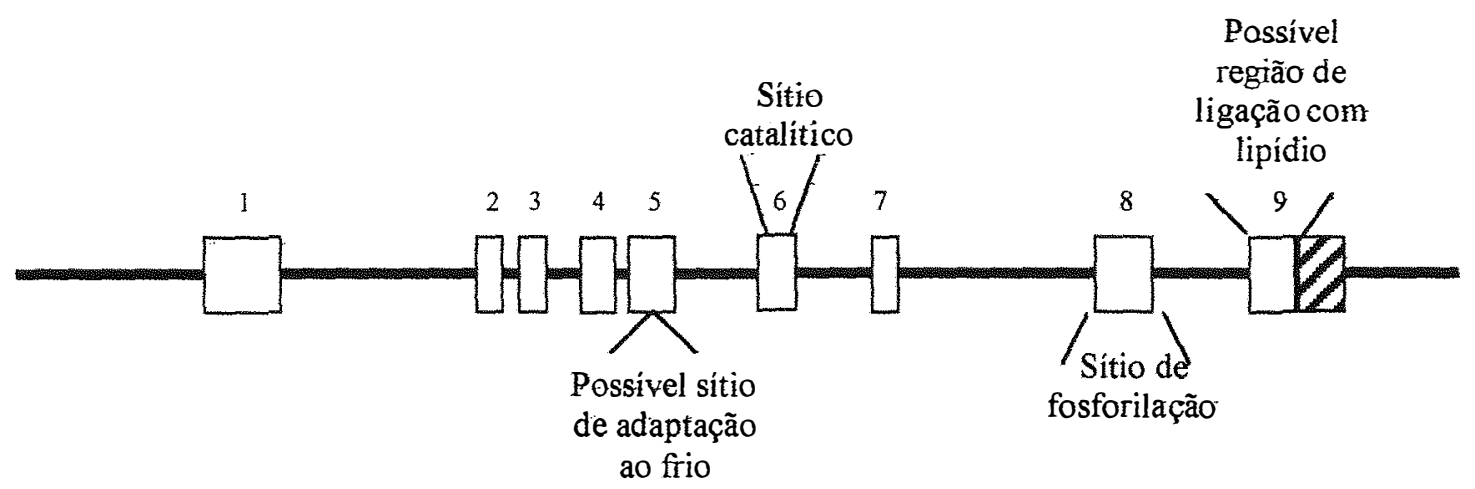

Figura 4: Organização genômica da HSL humana. (ㅁ), exons; (一), íntrons (Langin et al, 1996).

A organização complexa do gene sugere a existência de vários promotores. específicos para cada tecido (Grober et al., 1997). Grober et al. (1997), propuseram que determinados exons utilizados em tecidos específicos, são desativados em outros (específico para testículos, tecido adiposo entre outros).

Em camundongos, Laurin et al., (2000) encontraram 5 extremidades 5' distintas, que correspondem a diferentes exons, demonstrando a possibilidade de regulação transcricional diferencial da HSL em diferentes tecidos, dependendo das condições fisiológicas diversas. Este comportamento foi inicialmente demonstrado para genes constitutivos ("housekeeping" genes), mas agora tem sido demonstrado também para genes com expressão em diversos tecidos.

Devido à sua localização na via lipolítica, iniciando a hidrólise dos TAG dos adipócitos (Vaughan et al., 1964; Belfrage, 1984), credita-se a HSL o papel de enzima limitante neste processo (Belfrage, 1985; Langin et al., 1996).

Apesar da fosforilação (ativação) da HSL ser regulada por mecanismos hormonais e neuronais, através da proteína quinase A (Belfrage, 1985; Langin et al., 1996; Garton et al., 1989), a defosforilação não é hormonalmente controlada e envolve as proteínas fosfatase 2A e 2C e fosfodiesterase 3 (Olsson \& Belfrage, 1987; Olsson \& Belfrage, 1988; Degerman et al., 1998), que atua na degradação do AMPc (Rahn et al., 1994; Belfrage, 1985).

Em contrapartida, a atividade da HSL pode ser inibida também através de uma retroalimentação negativa (feedback negativo) a partir da sua própria atividade, (Jepson \& Y̌eaman, 1992; Berraondo \& Martinez, 2000), prevenindo a acumulação deletéria dos 
ácidos graxos e principalmente evitando o consumo total das reservas corporais dos animais.

A atividade da HSL parece também ser modulada por um mecanismo onde estimulação hormonal facilita a interação da HSL com a gota de lipídio na célula (Okuda et al., 1966), sendo que a integridade da gota lipídica é fundamental para a ação da HSL (Morimoto et al., 2000).

$\mathrm{O}$ adipócito possui uma estrutura grande em relação a outras células, e contém as reservas de energia na forma de triacilglicerol envolta em uma camada fosfolipídica. Pouco se sabe sobre as proteínas que recobrem a gota lipídica, e na última década (Greenberg et al., 1991; Servetnick et al., 1995; Brasaemle et al., 1997; Morimoto et al., 1997), esta camada vem sendo estudada, resultando em trabalhos que documentaram bem duas proteínas presentes na estrutura que recobre a gota lipídica, as chamada perilipinas e as proteínas de diferenciação do adipócito (ADRP), que em humanos é conhecida como adipofilina (Londos et al., 1999). Outras proteínas como as proteínas capsulares (Wang \& Fong, 1995) e a vimentina (Franke et al., 1987), foram achadas próximas à superfície da gota lipídica no adipócito.

Os RNAm das ADRP estão presentes em diversos tecidos e linhagens celulares, como adipócitos, células de Leydig e fibroblastos de ratos, entre outros (Brasaemle et al., 1997). A ADRP está presente no início da diferenciação de adipócitos, sendo substituída pelas perilipinas no final do estágio de crescimento (Brasaemle et al., 1997). Recentemente dois trabalhos descreveram o DNAc de outras duas proteínas do adipócito, denominadas de TIP47 (Diaz \& Pfeffer, 1998) que possui 40\% de similaridade com a ADRP, e a proteína S3-12, ainda pouco estudada. A TIP 47 parece estar envolvida com o transporte de manose 6 fosfato entre endossomos e o complexo de Golgi. Os RNAm das perilipinas, ADRP e S312 , possuem alta expressão no tecido adiposo em relação a outros tecidos.

As perilipinas pertencem a uma família abundante de proteínas que são fosforiladas pelo AMPc-PKA em parelelo à hidrólise de TAG, e que revestem a gota lipídica de adipócitos e células esteroidogênicas do córtex da adrenal, testículos e ovários (Greenberg et al, 1991 e 1993; Servetnick et al., 1995; Brasaemle et al., 1997). Greenberg et al (1993), isolaram duas classes de perilipinas, a A $(56 \mathrm{kDa})$ e a B $(46 \mathrm{kDa})$, que são expressas tanto em células esterodoigênicas quanto adipócitos, e a perilipina $\mathrm{C}(42 \mathrm{kDa})$, também 
abundante em células esteroidogênicas não foi encontrada em adipócitos (Servetnick et al., 1995).

Londos et al. (1999), demonstraram que as perilipinas são isoformas de um mesmo gene que sofre "splicing" alternativo de seu RNAm, formando as perilipinas A, B e C, sendo a A, a mais abundante inclusive em células 3T3-L1 (Brasaemle et al., 2000).

Estudos usando adipócitos 3T3-L1 (Brasaemle et al., 1999) demonstraram que em células não estimuladas, a HSL se encontra distribuída no citoplasma, mas move-se para a superficie da gota lipídica quando sob estimulação lipolítica. A utilização de isoproterenol em ratos provocou a translocação da HSL do citosol para a gota lipídica ao mesmo tempo que a perilipina foi fosforilada (Clifford et al., 2000), portanto, altas taxas de lipólise envolvem mecanismos de translocação e fosforilação de proteínas presentes na superfície da gota lipídica e que parecem também estar envolvidas na mobilização de reservas.

Morimoto el al. (2001), utilizando vários fatores lipolíticos (norepinefrina, isoproterenol, forscolina, dibutiril- AMPc e teofilina), não observaram aumento na atividade da HSL, mas houve uma indução da translocação desta enzima do citosol para a superfície da gota lipídica, sendo que de $80 \%$ a $90 \%$ da HSL se encontrava na superfície da gota após 1 hora de incubação com aqueles fatores. Estes dados sugerem que o evento crítico na lipólise pode não ser somente um aumento na atividade catalítica da enzima nem sua abundância por si só, mas também a translocação e interação da HSL com as proteínas da gota lipídica (Vernon et al., 1993).

Adaptações a um novo estado fisiológico e nutricional podem modificar a abundância da HSL, como em vacas e ovelhas, onde a restrição alimentar pouco (em vacas) ou praticamente nada (em ovelhas) aumentou o RNAm da HSL (Bonnet et al., 1998), sugerindo a ocorrência de uma regulação pós traducional em um curto prazo (fosforilação/defosforilação) e uma regulação pré traducional em um longo prazo (abundância de RNAm), já que são necessários alguns dias (no mínimo 48 horas) para se observar uma mudança significativa (aumentos de 2 vezes) no RNAm da HSL (Sztalryd \& Kraemer, 1994).

Em ratas no fim da prenhez, apresentaram níveis mais altos de RNAm da HSL, um período de intensa mobilização de lipídios (Hidalgo et al., 1994) e como comentado anteriormente, mudanças sazonais na massa do tecido adiposo, também foram associadas a variações no RNAm da HSL em marmotas (Wilson et al., 1992). 
Slavin et al. (1994), estudando a regulação hormonal da HSL em adipócitos isolados de ratos, verificou que a HSL foi regulada a curto prazo (fosforilação/defosforilação), pela epinefrina, glucagônio e homônio do crescimento e que somente a dexametasona foi capaz de alterar os niveis de RNAm da HSL, isto talvez tenha ocorrido pelo curto período de incubação com a ST a que o tecido foi submetido ( 24 horas), não sendo suficiente para proporcionar aumentos na concentração de RNAm da HSL.

Embora estes dados não sejam conclusivos, são as primeiras demonstrações de regulação da abundância de RNAm da HSL em tecido adiposo.

\subsection{Somatotropina e a regulação da Lipólise}

O manejo das reservas corporais é fundamental para maximizar a eficiência produtiva durante a prenhez e a lactação. A regulação do metabolismo do tecido adiposo pode ser agudo (curto prazo), envolvendo sinais homeostáticos como as catecolaminas e insulina na estimulação da lipólise e lipogênese, respectivamente (Bell et al., 1994). Controles crônicos ou homeorréticos, controlam o fluxo de nutrientes em diversos tecidos, de forma integrada, para suportar um determinado estado fisiológico. A ST é um exemplo de um regulador crônico do metabolismo do tecido adiposo que age alterando a resposta dos tecidos a sinais homeostáticos (Bauman e Vemon, 1993).

Lanna et al. (1994; 1995), demonstraram que os efeitos da ST sobre a lipólise são primariamente causados por uma diminuição na resposta do tecido adiposo à adenosina, um agente autócrino/parácrino. Esses efeitos são notavelmente semelhantes aos observados durante períodos de subnutrição em ratos (Chohan et al., 1984). O jejum de ruminantes resulta em aumento na resposta lipolítica a uma infusão in vivo de catecolaminas (Frohli \& Blum, 1988), gerando curvas de resposta muito semelhantes às observadas após tratamento com ST (McCutcheon \& Bauman, 1986; Sechen et al., 1989 e 1990). Jejum em humanos causa o mesmo padrão de aumento na liberação de ácidos graxos não esterificados em resposta a infusões de norepinefrina in vivo, mas como observado por Lanna et al. (1995) com tratamento com ST, estas mudanças do efeito do jejum não foram observadas quando testadas in vitro (Amer et al., 1981). Isto ocorre, provavelmente, porque in vitro não há presença de adenosina no meio (Lanna et al., 1995). 
O jejum reduz a sensibilidade do tecido adiposo à adenosina, sem alterar o número de receptores (Chohan et al., 1984). Da mesma forma, após tratamento com bST a sensibilidade à adenosina decresce (Lanna et al., 1995) sendo que, o número de receptores da adenosina no tecido adiposo não é alterado pela ST em ovinos (Vernon et al., 1991 e Doris et al., 1996) ou bovinos (Housecknecht \& Bauman, 1997). Estes autores também observaram que não houve ałteração na quantidade de Gi1 e Gi2 e portanto sugerem que o efeito envolva a funcionalidade das proteínas $\mathrm{G}$.

A adenosina se liga ao receptor $A_{1}$ e estimula a proteína Gi que por sua vez inibe a adenilato ciclase (Londos et al., 1980; Honnor et al., 1985). Portanto, a menor eficiência de estimulação do eixo receptor-Gi-adenilato ciclase parece ocorrer em tecido adiposo de animais submetidos a jejum ou tratados com ST. Vernon et al. (1988), observaram menor resposta à estimulação antilipolítica de $\alpha$-adrenérgicos em tecido adiposo de ovinos mantidos em cultura por $48 \mathrm{~h}$ na presença de ST, o que parece confirmar uma redução na atividade da proteína $\mathrm{Gi}$ (Lanna et al, 1995), que pode ocorrer através de três mecanismos principais: uma diminuição na quantidade de Gi (Doris et al, 1994); a habilidade da Gi em interagir com a adenilato ciclase (Doris et al., 1998) e a alteração na distribuição da Gi (Yip \& Goodman, 1999).

Durante o início da lactação, pelo menos em ratos, há um aumento na quantidade das proteínas Gs e Gi (Ros et al., 1992). Estudos corn a linhagem de células Nb2 demonstram que a ST aumenta a quantidade da subunidade $\beta$ da proteína heterotrimérica Gi (Larsen, 1992). Um aumento na quantidade da subunidade $\beta$ poderia resultar em decréscimo da proporção da subunidade $\alpha$ livre para conectar e inibir a adenilato ciclase.

Em virtude destas ações sobre as proteínas G, a ST altera também a atividade da HSL: em adipócitos 3T3-F442A, a ST aumentou a atividade total da HSL (Dietz e Schwartz, 1991), em ratas lactantes o tratamento com ST aumentou a atividade total da HSL (Vernon et al., 1993), e em ruminantes aumentos na atividade da HSL foram observados com o início da lactação (Smith \& McNamara, 1990).

O tratamento com ST exógena em vacas em lactação, não alterou a taxa máxima de lipólise determinada em incubações com $\beta$-adrenérgicos e adenosina deaminase (Lanna et al., 1995) ou em ratas lactantes (Vernon et al., 1987), ou ainda em explantes de tecido adiposo mantidos em culturas de longa duração com ST de ovinos (Vernon et al., 1988) e bovinos (Lanna et al., 1994). Isto indica que além da ST, o estabelecimento da lactação (Iliou \& 
Demame, 1987), a subnutrição (Amer et al., 1981) e o envelhecimento (Hoffinan et al., 1984) não alteram a capacidade máxima de lipólise.

Como discutido acima, resultados obtidos por Lanna et al. (1995), medindo a atividade total (enzima ativada) suportam a hipótese de que não há correlação entre tratamento com ST e capacidade máxima lipolítica, nem há notável alteração na atividade da HSL. Entretanto, nenhum trabalho com bovinos ou suínos, até agora, procurou avaliar se a expressão da HSL e Gið2 a nível de transcrição é alterada pela ST.

\subsection{Sitema ST/Insulin-like growth factor -1 (IGF-1)}

O manejo das reservas corporais é de grande importância para maximizar a eficiência produtiva durante a prenhez, a lactação e o crescimento. Controles crônicos ou homeorréticos controlam o fluxo de nutrientes para suportar determinado estágio fisiológico e a ST é um exemplo de regulador crônico do tecido adiposo que age alterando as respostas a sinais homeostáticos, como exposto anteriormente.

A ST afeta múltiplos tecidos de forma direta e indireta. A forma indireta envolve os IGFs (insulin like-growth factor), que tem efeitos importantes sobre a musculatura esquelética, o figado e a glândula mamária. No tecido adiposo, a ação da ST é direta, ou seja, não envolve os IGFs (Etherton \& Smith, 1991).

Os IGFs e a insulina são hormônios proteicos com estrutura primária semelhante $(50 \%$ de homologia) e se ligam a receptores similares, estimulando vários eventos celulares em comum. Os receptores da insulina reconhecem fracamente os IGF-I e IGF-II, por outro lado, os receptores de IGF-I reconhecem preferencialmente IGF-I, mas também IGF-II e insulina com alta afinidade (Ullrich et al., 1986).

A partir da ligação em seus receptores, tanto dos IGFs quanto da insulina, cada hormônio induz a autofosforilação do seu receptor, seguido da ativação de uma tirosina quinase inerente a esses receptores, que fosforila outras proteínas, incluindo o IRS-1 (White \& Kahn, 1994; Sun et al., 1995; Lavan et al., 1997) e IRS-2 (Patti et al., 1995), que age em outro substrato como a PI3-K (fosfatidilinositol 3-quinase), um segundo mensageiro capaz de ativar a PKC (proteína quinase $\mathrm{C}$ ), responsável por diversas respostas fisiológicas, dentre elas, $\mathrm{o}$ aumento na concetração de $\mathrm{Ca}^{+2}$ intracelular. 
A expressão in vitro da família das proteínas IRS em adipócitos, demonstram que todas podem mediar o transporte de glucose induzido pela insulina (Zhou et al., 1997).

Em células HIRcB e adipócitos 3T3-L1 tratados com inibidores da proteína Gi $\alpha$ (toxina pertussis) e inibidores da Gi $\beta \gamma$ (Dalle et al., 2001), no estado basal, ambas Gi $\alpha$ e $\beta$ estavam ligadas ao receptor do IGF-I e depois do estímulo houve um aumento da associação da Gia, concomitante ao decréscimo da associação da Giß com o receptor de IGF-I, demonstrando que a proteína Gi parece estar envolvida na via de sinalização do IGF-1 em alguns tipos de células.

Os níveis circulantes de ST em vacas em lactação, estão relacionados ao status nutricional, com as concentrações de ST aumentando quando o consumo de nutrientes é inferior aos requerimentos (Hove \& Blom, 1973). Maiores concentrações de ST estimulariam o tecido adiposo a reduzir a utilização de nutrientes para conversão em lipídios e, como discutido acima, facilitariam a lipólise.

Quando o consumo de nutrientes é adequado, o tratamento com ST causa um aumentona concentração de IGF-I, que estimula a utilização de nutrientes pela musculatura esquelética e pela glândula mamária (Bauman \& Vernon, 1993). Em outras palavras, os níveis circulantes de IGF-1 parecem ser função do estímulo da ST e da capacidade dos tecidos em responder a este estímulo, o que parece depender de um adequado aporte de nutrientes

Portanto, a ST inibe o uso de nutrientes e/ou aumenta a sua mobilização no tecido adiposo, ao mesmo tempo que estimula a utilização de nutrientes por outros tecidos. A modulação através do eixo ST/IGF-I é particularmente interessante em mamíferos, pois durante a lactação não seria interessante para o organismo, o direcionamento de nutrientes para o tecido adiposo. 


\section{MATERIAL E MÉTODOS}

\subsection{Animais}

Os bovinos utilizados como fonte de tecido foram fềmeas adultas, com peso aproximado de $400 \mathrm{~kg}$. Os animais estavam em regime de confinamento recebendo alimentação ad libitum, no estábulo experimental do Laboratório de Bromatologia do Departamento de Produção Animal da ESALQ.

\subsection{Biópsias}

Os tecidos foram obtidos por biópsia como descrito por Lanna et al. (1995). O tecido adiposo subcutâneo da região dorsal posterior foi retirado (Apêndice A, Figura 13) e transferido para uma solução tampão de transporte contendo HEPES $(25 \mathrm{mM})$ e $\mathrm{NaCl}$ $(0,15 \mathrm{M})$, antibióticos $(60 \mu \mathrm{g} / \mathrm{ml}$ de penicilina, $100 \mu \mathrm{g} / \mathrm{ml}$ de estreptomicina, $10 \mu \mathrm{g} / \mathrm{ml} \mathrm{de}$ neomicina, $5 \mu \mathrm{g} / \mathrm{ml}$ de anfotericina/Sigma Chemical Co.), $\mathrm{pH}$ 7,4 e à temperatura de $37^{\circ} \mathrm{C}$. As amostras foram transportadas para o laboratório dentro de 10 minutos após a biópsia para preparação dos explantes utilizados nas culturas de tecido de longa duração.

\subsection{Preparo do tecido para culturas}

As amostras de tecido adiposo foram transferidas do tampão de transporte para um recipiente com meio 199 (com sais de Earle, L-glutamina, $25 \mathrm{mM}$ de bicarbonato de sódio e $25 \mathrm{mM}$ de HEPES), suplementado com 5,6 $\mathrm{mM}$ de acetato de sódio e antibióticos (60 $\mu \mathrm{g} / \mathrm{ml}$ de penicilina, $100 \mu \mathrm{g} / \mathrm{ml}$ de estreptomicina, $10 \mu \mathrm{g} / \mathrm{ml}$ de neomicina, $5 \mu \mathrm{g} / \mathrm{ml} \mathrm{de}$ anfotericina). As amostras foram mantidas a $37^{\circ} \mathrm{C}$ e pH 7,4 sob placa quente enquanto os explantes individuais de aproximadamente $30 \mathrm{mg}$ eram preparados com o auxílio de tesouras e bisturi (Apêndice A, Figura 14). 


\subsection{Culturas de longa duração}

Após duas lavagens em meio de cultura, os explantes foram transferidos para placas de cultura de tecidos com 24 poços, contendo $2,5 \mathrm{ml}$ do meio 199 descrito acima, por poço. As placas foram incubadas em uma estufa com atmosfera controlada de $5 \%$ de $\mathrm{CO}_{2}$, a $37^{\circ} \mathrm{C}$ por $48 \mathrm{~h}$ (Apêndice A- Figura 15).

Para avaliar os efeitos de exposição do tecido adiposo à somatotropina (ST), os explantes foram incubados em meio $199 \mathrm{com}$ : a) $100 \mathrm{ng} / \mathrm{ml}$ de insulina mais $10 \mathrm{nM}$ de dexametasona e b) $100 \mathrm{ng} / \mathrm{ml}$ de insulina mais $10 \mathrm{nM}$ de dexametasona e $100 \mathrm{ng} / \mathrm{ml}$ de ST.

A insulina foi solubilizada em $0,001 \mathrm{~N}$ de $\mathrm{HCl}$ a $\mathrm{pH}$ 3.0. A somatotropina recombinante (n-metionil bST) utilizada nos experimentos foi solubilizada em água estéril para concentração final de $10 \mathrm{mg} / \mathrm{ml}$ e $75 \mathrm{mM}$ de bicarbonato de sódio e, posteriormente, diluída em solução estéril de bicarbonato de sódio (pH 9).

A dexametasona foi dissolvida em etanol. Os hormônios foram adicionados ao meio de cultura imediatamente antes dos explantes serem transferidos para as placas de cultura.

O meio de cultura foi trocado a cada 24 horas para evitar o problema da redução da concentração dos hormônios ou substratos em função da sua incorporação ou degradação pelos explantes de tecido adiposo. Este procedimento também evita o acúmulo de produtos do metabolismo que possam ter efeitos sobre os explantes.

Ao final das incubações, os explantes de tecido adiposo foram retirados, congelados e armazenados a $80^{\circ} \mathrm{C}$ negativos até serem utilizados em ensaios de atividade enzimática e extração de RNA.

\subsection{Ensaio da atividade da HSL}

A atividade da HSL foi determinada através da metodologia descrita por Vernon et a1. (1993), incubando o homogenato do tecido adiposo com a gota de lipídio dos próprios adipócitos. Os ácidos graxos não esterificados foram separados utilizando a técnica de Dole (1956). O tecido adiposo foi homogeneizado em uma solução tampão $(0,25 \mathrm{nM}$ de sucrose/ $1 \mathrm{nM}$ EDTA/ $10 \mathrm{nM}$ Tris/ $\mathrm{HCl}$ ), $\mathrm{pH} \mathrm{7,4} \mathrm{a} 4^{\circ} \mathrm{C}$ e posteriormente centrifugado a $7800 \mathrm{xg}$. Uma alíquota de $0,5 \mathrm{ml}$, incluindo o sobrenadante de gordura, foi adicionada a $0,5 \mathrm{ml}$ de tampão fosfato $\mathrm{pH}$ 7,0 (40 mg BSA/ml, $10 \mathrm{mM} \mathrm{MgCl} 2,20 \mathrm{nM}$ de fosfato de sódio, $1 \mathrm{mM}$ 
ATP), sendo incubada durante 1 hora a $37^{\circ} \mathrm{C}$. O produto final da reação foi congelado para interromper a reação. Para analisar a concentração de NEFA livres foi utilizado o kit comercial NEFA C (WAKO/Alemanha). Os resultados foram expressos em nmoles de NEFA liberados por hora e por miligrama de proteína nos infranadantes. A concentração de proteínas nos infranadantes foi determinada pelo método de biureto (Gornal, 1949), utilizando-se como padrão a albumina sérica bovina (Sigma Chemical Co.).

\subsection{Avaliação da taxa de lipólise}

Com o objetivo de avaliar o efeito da ST sobre as taxas de lipólise, foram retiradas alíquotas do meio 199 ao finnal das incubações. Foram determinadas concentrações de NEFA no meio utilizando o kit NEFAc (WAKO). As taxas de lipólise foram expressas em nmoles de ácidos graxos liberados no meio por grama de tecido adiposo.

\subsection{Avaliação da expressão gênica (concentração de RNAm) \\ 3.8.1. Extração de RNA total}

As extrações de RNA total foram realizadas com o reagente Trizol (Gibco BRL). Explantes do tecido adiposo da cultura de aproximadamente $50 \mathrm{mg}$ foram homogeneizados em $0,75 \mathrm{ml}$ do reagente e, posteriormente, incubadas por 5 minutos à temperatura ambiente para permitir completa dissociação de complexos nucleoproteicos. A seguir, foram adicionados $0,2 \mathrm{ml}$ de clorofómmio e agitados vigorosamente por 15 segundos. As amostras foram incubadas de 2 a 15 minutos à temperatura ambiente e centrifugadas por 15 minutos. Após a separação das fases, o RNA que permanece na fase aquosa foi precipitado com

isopropanol e centrifugado. O pellet resultante foi lavado em etanol a 75\%. Após a lavagem, o pellet foi seco à temperatura ambiente e ressuspendido com $\mathrm{H}_{2} \mathrm{O}_{\mathrm{DEPC}}$ (água estéril-filtrada em filtro com poros de 0,22 micra- tratada com 0,01\% de dietilpirocarbonato). A quantificação do RNA total foi feita em espectrofotômetro (260 - 280 $\mathrm{nm})$.

Aproximadamente $0,8 \mu \mathrm{g}$ de RNA total foi aplicado em gel de 1,5\% agarose em condições denaturantes, com $1 \%$ de formaldeído para observar a integridade do RNA. Para 
as amostras em que a integridade do RNA foi demonstrada, foram procedidas as reações de transcriptase reversa $(\mathrm{RT})$.

\subsubsection{RT ("transcriptase reversa")}

Uma alíquota de $1 \mu \mathrm{g}$ de RNA total foi utilizada na síntese do DNA complementar (DNAc) à população de RNAs. A síntese da primeira fita de DNAc foi catalisada pela enzima Transcriptase Reversa “Superscript II RNAse H”' (Gibco BRL), utilizando-se como iniciador ("primer") hexâmeros randômicos. Após a síntese, o DNAc foi amplificado através de reação de PCR, utilizando 0,05 $\mathrm{u} / \mu \mathrm{l}$ da enzima Taq DNA polimerase, IX PCR buffer, 1,5 mM $\mathrm{MgCl}_{2}, 0,2 \mathrm{mM}$ dNTP e $10 \mathrm{pM} / \mu \mathrm{l}$ dos "primers" (Operon Technologies, Inc) senso e antisenso para os genes de bovinos da HSL, da proteína Gio2 e da beta actina (gene constitutivo).

\subsubsection{Desenho dos "primers" e construção dos fragmentos}

Inicialmente, foi utilizado tecido adiposo fresco de bovinos para proceder à extração de RNA e RT-PCR, para obtenção dos fragmentos desejados e posterior clonagem.

A seqüência dos "primers" para HSL foi determinada com base nos dados publicados por Lee \& Crooker (1996) no Genbank ( $n^{\circ}$ de acesso U78042) para amplificar uma seqüência de $320 \mathrm{pb}$ (nativo) e $270 \mathrm{pb}$ (competidor). Para a beta actina os primers foram feitos de acordo com a seqüência publicada por John \& Bilodeau-Goeseels (1999) no Genbank ( $\mathrm{n}^{\circ}$ de acesso AF191490), para amplificar um fragmento de 229pb (nativo) e $182 \mathrm{pb}$ (competidor). Para a proteína Gi $\alpha 2$ foram elaborados “primers" degenerados (Wilkie et al., 1994) baseados na homologia entre Gial bovino e Gia2 de humano, segundo Nukada e Beals (1986) e Beals (1987), respectivamente, para amplificar um segmento de 519 pb (nativo) e 460 pb (competidor) (ver Tabela 4 e Figuras $5 \mathrm{a}$ e 5b).

Os fragmentos nativos foram obtidos utilizando-se os primers senso e antisenso, e os fragmentos competidores foram obtidos através da utilização de um primer de deleção composto em parte, pela seqüência do "primer" antisenso (Kotake et al., 1996). Ambos os " "primers" senso e anti-senso-deleção juntos na reação provocaram uma deleção de: 59 pb para HSL e Gi, e $50 \mathrm{pb}$ para a beta actina, de forma que na eletroforese, o competidor poderia ser identificado através de seu tamanho reduzido em relação ao nativo. 
Tabela 4: Sequência dos "primers" baseados em dados publicados na literatura

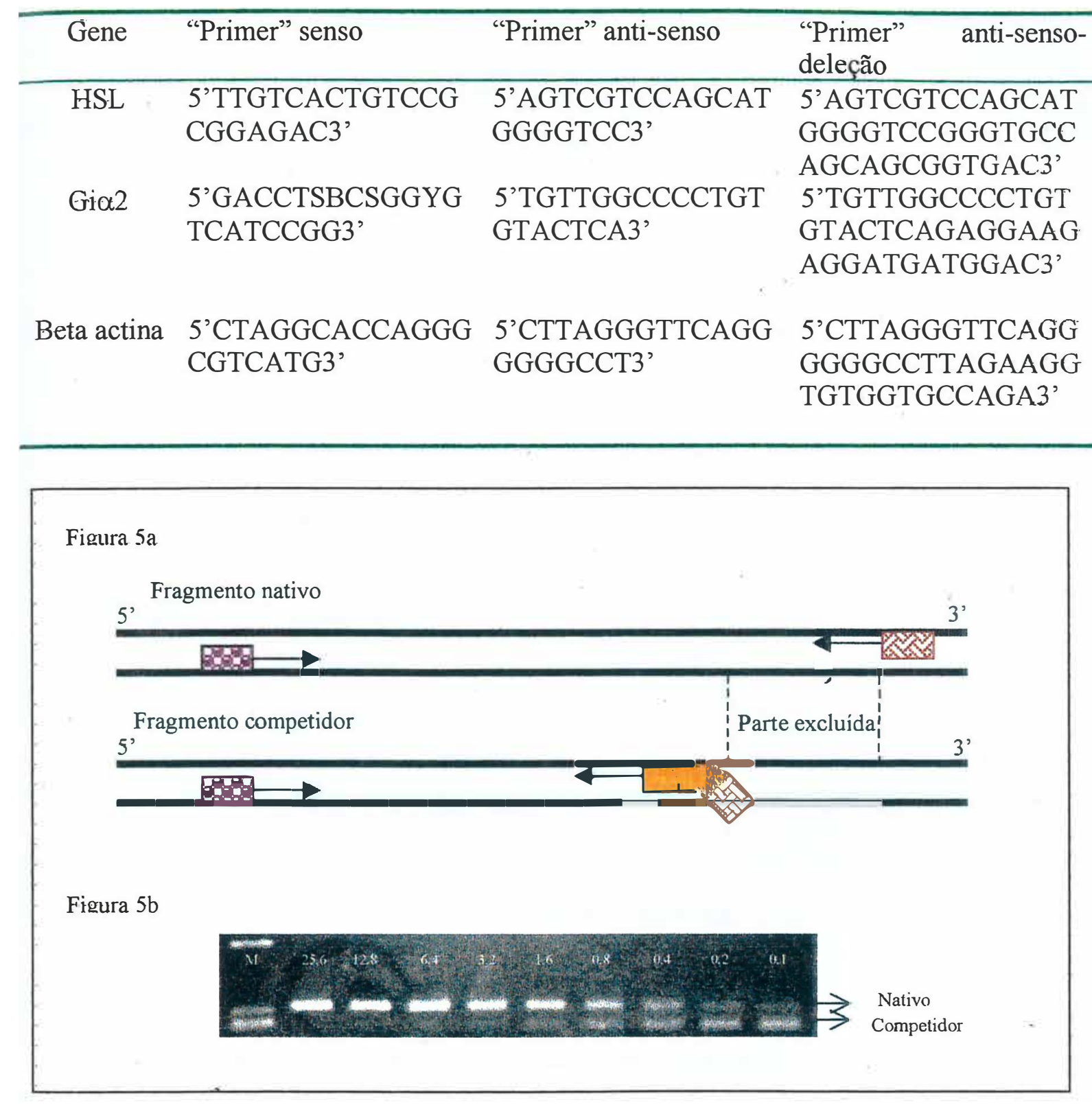

Figura 5a. Desenho esquemático da construção dos fragmentos nativo e competidor utilizados para os genes da HSL, Giळ2 e beta actina bovino.

Figura 5b. Exemplo de curva padrão (gene da HSL). 


\subsubsection{Reação de PCR}

Os programas utilizados para a amplificação de cada gene foram desenvolvidos após testes iniciais de diferentes temperaturas e teores de $\mathrm{Mg}^{++}$:

$\begin{array}{llll}1^{\circ} \text { ciclo } & \text { Desnaturação : } & 95^{\circ} \mathrm{C} & 5 \text { minutos } \\ & \text { Anelamento : } & 52^{\circ} \mathrm{C}(\mathrm{HSL}) ; 55^{\circ} \mathrm{C} \text { (Gi e beta actina) } 1 \text { minuto } \\ & \text { Extensão : } & 74^{\circ} \mathrm{C} & 1 \text { minuto } \\ 2^{\circ}-29^{\circ} \text { ciclo } & \text { Desnaturação : } & 95^{\circ} \mathrm{C} & 1 \text { minuto } \\ & \text { Anelamento : } & 52^{\circ} \mathrm{C}(\mathrm{HSL}) ; 55^{\circ} \mathrm{C}(\mathrm{Gi} \text { e beta actina) } 1 \text { minuto } \\ & \text { Extensão : } & 74^{\circ} \mathrm{C} & 1 \text { minuto } \\ 30^{\circ} \text { ciclo } & \text { Desnaturação : } & 95^{\circ} \mathrm{C} & 1 \text { minuto } \\ & \text { Anelamento : } & 52^{\circ} \mathrm{C}(\mathrm{HSL}) ; 55^{\circ} \mathrm{C} \text { (Gi e beta actina) } 1 \text { minuto } \\ & \text { Extensão : } & 74^{\circ} \mathrm{C} & 10 \text { minutos }\end{array}$

Os produtos amplificados foram submetidos à eletroforese em gel de agarose 2,5\% de alta resolução, corados em $1 \mu \mathrm{g} / \mathrm{ml}$ de brometo de etídeo, e posteriormente fotografados em sistema de fotodocumentação digital (KODAK Digital Science, Electrophoresis Documentation and Analysis System 120).

Os géis foram analisados segundo o programa de análise do sistema de fotodocumentação (Kodak 1D), onde as bandas eram fixadas de acordo com os picos do gráfico de distribuição de pixels (número de pontos por $\mathrm{cm}^{2}$ da foto) e os resultados regredidos em "intensidade líquida" em relação a um padrão de intensidade do próprio programa.

\subsubsection{Clonagem}

Os fragmentos de cada gene foram submetidos à eletroforese em gel de agarose 1,0 $\%$, para posterior eluição utilizando o Kit Concert (Gibco) e clonagem utilizando o Kit 
Sureclone Ligation (Gibco). O produto da clonagem foi diluído em TE (10mM Tris $\mathrm{HCl}$, pH8,0, $1 \mathrm{mM}$ EDTA), para uma concentração final de $50 \mathrm{ng} / \mu \mathrm{l}$ e adicionado $1 \mu \mathrm{l}$ desta solução diluída foi adicionada a $100 \mu \mathrm{l}$ de bactérias competentes Escherichia coli da linhagem JM109 (Promega). As células foram deixadas por 20 minutos em banho de gelo, seguindo-se um choque térmico a $42{ }^{\circ} \mathrm{C}$ por 50 segundos e, posteriromente, deixadas em banho de gelo por 2 minutos. Foram adicionados $0,950 \mathrm{ml}$ de meio SOB (Sambrook) às células e deixadas por $2 \mathrm{~h}$, à $37^{\circ} \mathrm{C}$ sob agitação. Após a transformação, foram plaqueadas $100 \mu \mathrm{l}$ da cultura e o restante foi centrifugado e, posteriormente, adicionado em outra placa. O plaqueamento foi realizado em meio LB com adição de ágar contendo $50 \mu \mathrm{g} / \mathrm{ml} \mathrm{de}$ ampicilina, $0,1 \mathrm{mM} / \mathrm{ml}$ de IPTG e $40 \mu \mathrm{g} / \mathrm{ml}$ de X-Gal incubadas à $37^{\circ} \mathrm{C}$ por 16 horas.

Para extração do plasmídio as colônias selecionadas foram colocadas em tubo de ensaio contendo meio $\mathrm{LB} \mathrm{pH} \mathrm{7,5} \mathrm{(} 1 \%$ de bacto triptona; $0,5 \%$ de extrato de lêvedo, $0,5 \%$ de $\mathrm{NaCl}$ ) com $50 \mu \mathrm{g} / \mathrm{ml}$ de ampicilina, à $37^{\circ} \mathrm{C}$, com agitação a $250 \mathrm{rpm}$, durante toda a noite.

Foram coletados $1,5 \mathrm{ml}$ do tubo de ensaio e centrifugados a $7200 \mathrm{xg}$ por 30 segundos. O sobrenadante foi descartado e o "pellet" resultante foi ressuspendido em $200 \mu \mathrm{l}$ de GET ( $25 \mathrm{mM}$ de Tris $\mathrm{HCl}, 10 \mathrm{mM}$ de EDTA, pH 8,0). Foram adicionados $300 \mu \mathrm{l}$ de uma solução contendo $1 \%$ de SDS e $0,2 \mathrm{~N}$ de $\mathrm{NaOH}$, seguindo-se incubação em banho de geło por 5 minutos. Posteriormente, foram adicionados $300 \mu \mathrm{l}$ de acetato de potássio $3 \mathrm{M} \mathrm{e}$ procedendo-se a incubação em banho de gelo por 5 minutos e, posteriormente, centrifugação à temperatura ambiente, a $7200 \mathrm{xg}$ por 10 minutos. O sobrenadante foi transferido para um novo tubo e adicionados $10 \mathrm{mg} / \mathrm{ml}$ de RNAse A. Foi feita incubação à $37^{\circ} \mathrm{C}$ por 30 minutos, seguida da adição de $400 \mu \mathrm{l}$ de clorofórmio, homogeneização e centrifugação a $7200 \mathrm{xg}$, por 1 minuto. A fase superior foi coletada e a ela adicionado o mesmo volume de isopropanol absoluto, seguindo-se de centrifugação à temperatura ambiente, a $7200 \mathrm{xg}$ por 10 minutos. O sobrenadante foi descartado e adicionados $500 \mu \mathrm{l}$ de etanol $70 \%$. Foi realizada nova centrifugação, por 5 minutos, a $7200 \mathrm{xg}$. O "pellet" foi ressuspendido em $32 \mu \mathrm{l}$ de $\mathrm{H}_{2} \mathrm{O}_{\mathrm{MQ}}$ (água filtrada em filtro de 0,22 micra, que a torna estéril). Foram adicionados $8 \mu \mathrm{l}$ de $\mathrm{NaCl} 4 \mathrm{M}$ e $40 \mu \mathrm{l}$ de PEG (polietileno glicol) $13 \%$ e mantidos em banho de gelo por 20 minutos. Seguiu-se centrifugação à $4^{\circ} \mathrm{C}, 7200 \mathrm{xg}$, por 15 minutos. O sobrenadante foi removido e ao "pellet" resultante, foram adicionados $500 \mu \mathrm{lde}$ etanol $70 \%$, centrifugado à temperatura ambiente a $7200 \mathrm{xg}$ por 5 minutos. $\mathrm{O}$ "pellet" foi. ressuspendido em $20 \mu \mathrm{l}$ de $\mathrm{H}_{2} \mathrm{O}_{\mathrm{MQ}}$. 
Os clones selecionados (após digestão com as enzimas ECO RI e HIND III) foram sequenciados (kit PRISM ${ }^{\text {tm }}$ Dye Deoxy Termonator Cycle Sequencing-Perkin-Elmer) e os que apresentaram alta homologia com as sequência de DNAc publicadas (100\% no caso da HSL e beta actina, e homologia elevada para Gio2 entre diversas espécies) analisadas com o programa Macaw 2.0.5 (NCBI- Genbank), foram utilizados para determinar a faixa de coamplicação do nativo e competidor, o ${ }^{\circ}$ de ciclos ideal estimado para o PCR (Tabela 5) e para obter a curva padrão (Figura 5b) dos genes (Zhang \& Birne, 1999).

Tabela 5. Faixa de co-amplificação e $\mathrm{n}^{\circ}$ de ciclos ideal estimado de cada gene para o PCR

\begin{tabular}{ccc}
\hline Genes & Faixa de co-amplificação & $\mathrm{N}^{0}$ de ciclos ideal (antes do platô) no PCR \\
\hline HSL & $10^{-5}$ & 28 \\
Gia2 & $10^{-3}$ & 34 \\
Beta actina & $10^{-1}$ & 23 \\
\hline
\end{tabular}

\subsubsection{QC ("quantitative-competitive")}

Em uma segunda etapa, foi feita a análise quantitativa da expressão dos genes citados anteriormente, de acordo com o protocolo descrito por Zhang \& Birne (1999).

As curvas padrão (Figuras 6a; 7a e 8a) foram desenhadas a partir de triplicatas de 9 diluições seriais do nativo $(25,6 \mathrm{x} ; 12,8 \mathrm{x} ; 6,4 \mathrm{x} ; 3,2 \mathrm{x} ; 1,6 \mathrm{x} ; 0,8 \mathrm{x} ; 0,4 \mathrm{x} ; 0,2 \mathrm{x}$ e $0,1 \mathrm{x}$, sendo $\mathrm{x}$ igual a $10^{-5}$ fmol para a HSL; $10^{-3}$ para a proteína Gi e $10^{-1}$ para a beta actina) junto a quantidades constantes do competidor na reação de PCR (HSL: $10^{-5} \mathrm{fmol}$; Gi: $10^{-3}$ e beta actina: $\left.10^{-1}\right)$.

A avaliação da quantidade de transcritos foi feita de acordo com os protocolos de Reue (1998), Foley (1993); Tsai \& Wiltbank (1996) e Zhang \& Birne (1999). O produto da reaçâo de cada gene foi calculado através da intensidade do nativo comparada com a intensidade do competidor e sua taxa logarítmica foi regredida contra as quantidades logarítmicas iniciais do nativo para produzir a curva padrão. As amostras foram quantificadas diretamente no gel de agarose, através do programa de fotodocumetação Kodak 1D. O logarítmo da relação nativo/competidor dos animais analisados, foi comparado com a curva padrão para calcular as quantidades dos transcritos da HSL, da proteína Gi 2 e da beta actina nas amostras tratadas e não tratadas com ST. 


\subsection{Análise dos dados}

Análises estatísticas foram realizadas usando o teste $\mathrm{t}$ de "Student" para amostras pareadas (controle ou bST) utilizando o pacote estatístico SAS (SAS 6.12). 


\section{RESULTADOS E DISCUSSÃO}

As curvas padrão para cada gene foram obtidas a partir de corridas individuais em triplicatas das amostras obtidas por PCR, sendo possível observar nas figuras abaixo

(Figura 6a e 6b: HSL; 7a e 7b: Gia2; 8a e 8b: beta actina) a reprodutibilidade dos dados.

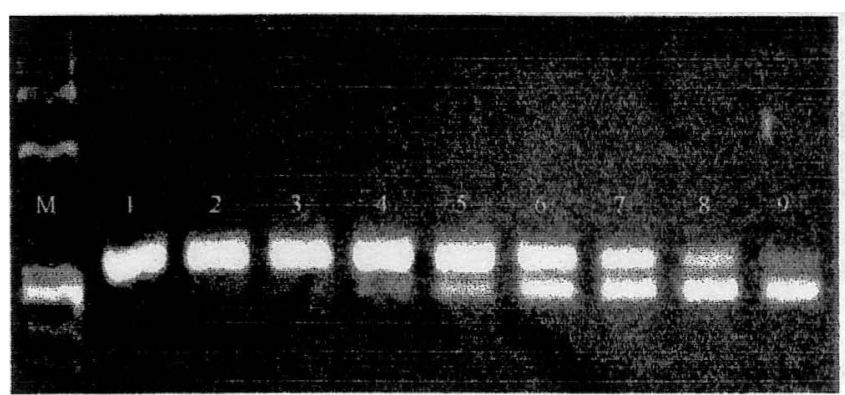

Figura 6a- Gel de agarose $3 \%$ em brometo de etídeo, da curva padrão do gene da HSL a $10^{-5} \mathrm{fmol}$, (M: marcador de peso). Canaletas 1 . $25 ; 6 \times 10^{-5}$ fmol; 2: $12,8 \times 10^{-5}$ fmol; $3: 6,4 \times 10^{-5}$ fmol; $4: 3,2 \times 10^{-5}$ finol; 5: $1,6 \times 10^{-5} \mathrm{fmol} ; 6: 0,8 \times 10^{-5} \mathrm{fmol} ; 7: 0,4 \times 10^{-5} \mathrm{fmol} ; 8: 0,2 \times$ $10^{-5}$ finol; 9: $0,1 \times 10^{-5} \mathrm{fmol}$.

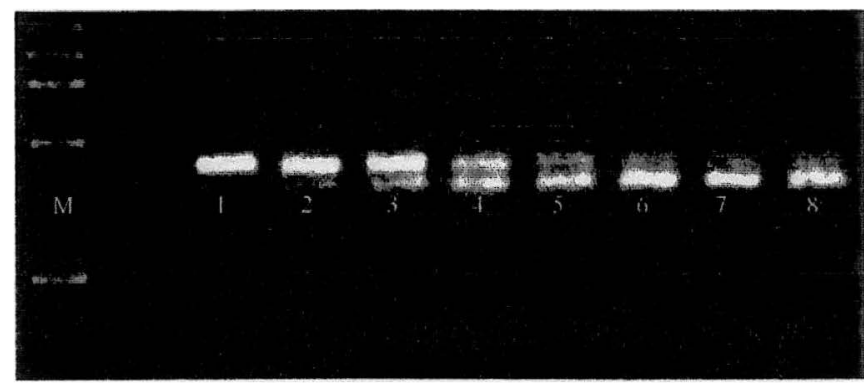

Figura 7a- Gel de agarose 3\% em brometo de etídeo, da curva padrão do gene da proteína Gia2 a $10^{-3} \mathrm{fmol}$, (M: marcador de peso)

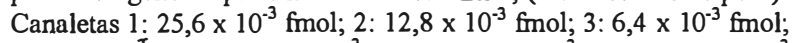
4: $3,2 \times 10^{-3} \mathrm{fmol} ; 5: 1,6 \times 10^{-3} \mathrm{fmol} ; 6: 0,8 \times 10^{-3} \mathrm{fmol} ; 7: 0,4 \times 10^{-3}$ fmol; : 8: $0,2 \times 10^{-3} \mathrm{fmol}$.

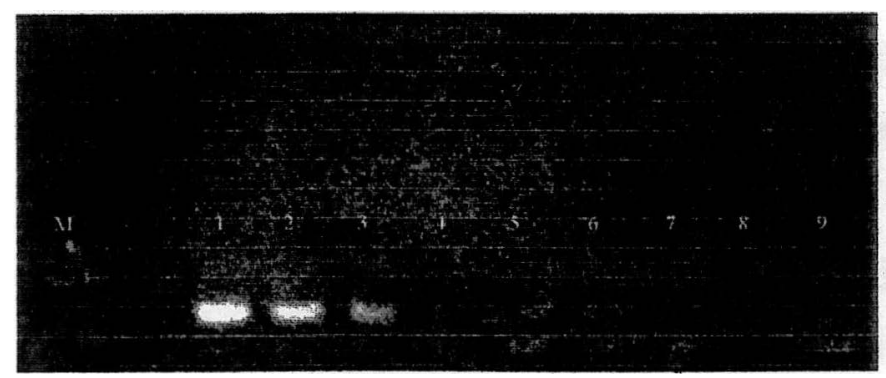

Figura 8a- Gel de agarose 3\% em brometo de etídeo, da curva padrão do gene da beta actina a $10^{-1} \mathrm{fmol}$, (M: marcador de peso). Canaletas 1 : $25,6 \times 10^{-1}$ thol; 2 : $12,8 \times 10^{-1}$ fmol; $3: 6,4 \times 10^{-1}$ fmol; $4: 3,2 \times 10^{-1}$ fmol; 5: $1,6 \times 10^{-1}$ fmol; 6: 0,8 $\times 10^{-1}$ fmol; 7: $0,4 \times 10^{-1} \mathrm{fmol} ; 8: 0,2 \times$ $10^{-1}$ finol; $9: 0,1 \times 10^{-1}$ fmol.

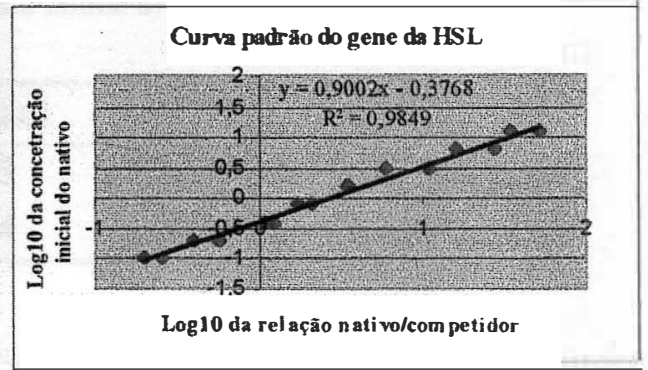

Figura 6b: Curva padrão para a HSL, na faixa de $10^{: 5}$ fmoles. O logarítimo das áreas dos picos națvo e competidor, em cada diluição, foram regredidos.

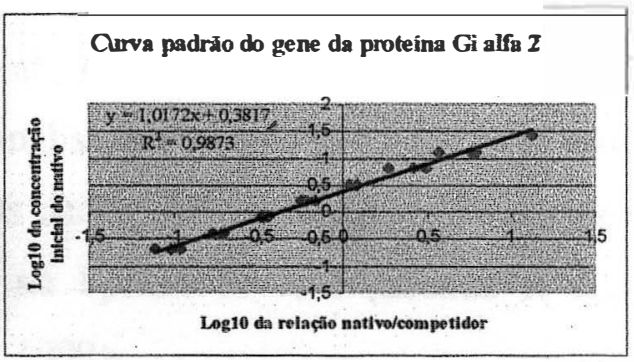

Figura 7b: Curva padrão para a proteína Gia2 na faixa de $10^{-3}$ fmoles. O logarítimo das áreas dos picos nativo e competidor, em cada diluição, foram regredidos.

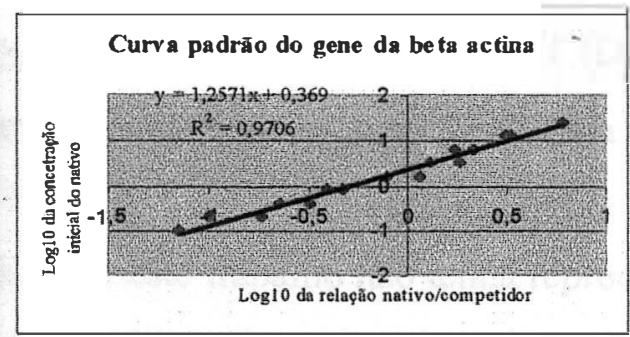

Figura 8b: Curva padrão para a beta actina na faixa de $10^{-1}$ fmoles. O logarítimo das áreas dos picos nativo e competidor, em cada diluição, foram. regredidos. 
A abundância do RNAm do gene da beta actina foi utilizado como padrão para a correção das amostras dos genes da HSL e Gi 2 . O tratamento com ST, não alterou a abundância de RNAm da beta actina, como esperado, por ser um gene constitutivo, demonstrando a sua eficiência para padronizar as amostras (Tabela 6).

Tabela 6: Quantificação do RNAm da beta actina sem e com ST ( $>>0,10)$

\begin{tabular}{ccc}
\hline Animal & Control & bST \\
\hline Média & 0,23 & 0,25 \\
Desvio & 0,14 & 0,20 \\
\hline
\end{tabular}

Devido à sua especificidade pelas ligações éster 1 e 3, a HSL é capaz de hidrolisar o os dois primeíros passos na lipólise, a hidrólise do triacilglicerol em diacilglicerol e então em monoacilglicerol (Fredrikson et al., 1981 e 1986). E o passo final no processo lipolítico, a conversão de monoacilglicerol em ácidos graxos livres e glicerol, é efetuada por outra enzima, a monoacilglicerol lipase (Fredrikson et al., 1986).

Neste estudo, para avaliar a lipólise, foi analisada a liberação de ácidos graxos livres no meio de cultura (Tabela 10- Apêndice B). Os dados corroboraram resultados de outros pesquisadores que avaliaram o efeito da ST na lipólise in vivo (Sechen et al., 1989; McCuctheon, 1986) e in vitro (Lanna \& Bauman, 1999).

Semelhante às avaliações da atividade lipolítica, no presente estudo a atividade da HSL teve um pequeno aumento $(\mathrm{p}<0,06)$ com o tratamento dos explantes com ST (Tabela 7). Estes resultados são consistentes com resultados anteriores da literatura que reportaram modestos aumentos na atividade da HSL em linhagens celulares tratadas com ST (Dietz \& Schwartz, 1991), em tecido adiposo de vacas em lactação tratadas com ST (Lanna et al.s 1995) e vacas no início da lactação (McNamara, 1991).

É possível que a forma de preparação utilizada neste trabalho não tenha reproduzido a estrutura da gota lipídica encontrada no adipócito (Greenberg et al., 1991; 1993). A redistribuição da HSL entre os componentes subcelulares pode ser um mecanismo importante de regulação da sua atividade (Egan et al., 1992), sendo a interação da HSL com a gota lipídica no adipócito intacto muito importante para descrever o efeito de uma substância lipolítica (Morimoto, 2000), como já sugerido por Belfrage em 1984 e ainda, 
que os sitemas in vitro podem não "imitar" as condições in vivo, principalmente pela heterogeneidade do tecido adiposo, como tamanho de células, números de receptores adrenérgicos e vascularização entre outros (Bowen et al., 1992; Bouchard et al., 1993).

Tabela 7. Efeito da ST na atividade da HSL após a cultura crônica de explantes de tecido adiposo por 48 horas em meio $199(n=5 ; p<0,05)$.

Atividade da HSL em nMol/mg proteína.h

Controle Com 100ng/ml de bST

Média

19.97

25.37

$\mathrm{SD}$

0,07

0,06

A medição da atividade enzimática pode ser, dependendo do gene, um excelente indicador do nível de expressão gênica. Infelizmente, como discutido acima, no caso da HSL isto parece não ocorrer. Já a medição da concentração de RNAm específicos de cada eznima é utilizada para avaliar alterações nas taxas de transcrição ou na estabilidade do RNAm de um gene. A maior parte das enzimas reguladoras envolvidas no metabolismo de carboidratos e na síntese de lipídios é regulada em nível de transcrição. Entretanto, poucos trabalhos procuraram avaliar alterações na expressão da HSL (Slavin et al., 1994; PleéGautier et al., 1996) e Gia2 (Yip \& Goodman, 1999) em tecido adiposo.

Dietz \& Schwartz (1991), observaram que a ST, necessitaria de um período mais longo para agir sobre a atividade total da HSL, sugerindo um aumento na síntese da enzima, devido a uma indução do gene da HSL. Este fato foi observado por Sztalryd \& Kraemer (1994), em tecido adiposo de ratos, que relataram a pequena mudança nos níveis da HSL durante o jejum, em um curto prazo (até 2 dias), mas a longo prazo (de 3 a 5 dias) verificou-se um aumento na abundância do RNAm da HSL. O jejum envolve aumento nos níveis circulantes de ST, embora outros muitos fatores também sejam alterados durante o jejum. No presente experimento pode ser observado um aumento na abundância de RNAm da HSL $(\mathrm{p}<0,06)$ com o tratamento de 48 horas de explantes de tecido adiposo de bovinos com ST (Tabela 8 e Figura 9 e 10).

Aumentos no fluxo de NEFA em curtos períodos, envolvem principaImente mudanças pós - traducionais relativas à fosforilação/defosforilação da enzima HSL 
(Vaughan et al., 1964; Fredrikson et al., 1981; Stralfors \& Belfrage, 1981; Sztalryd \& Kraemer, 1994). Já alterações na quantidade da enzima requerem mais tempo para serem observadas.

Tabela 8: Quantificação em fmol do RNAm da HSL sem e com ST $(p<0,06)$

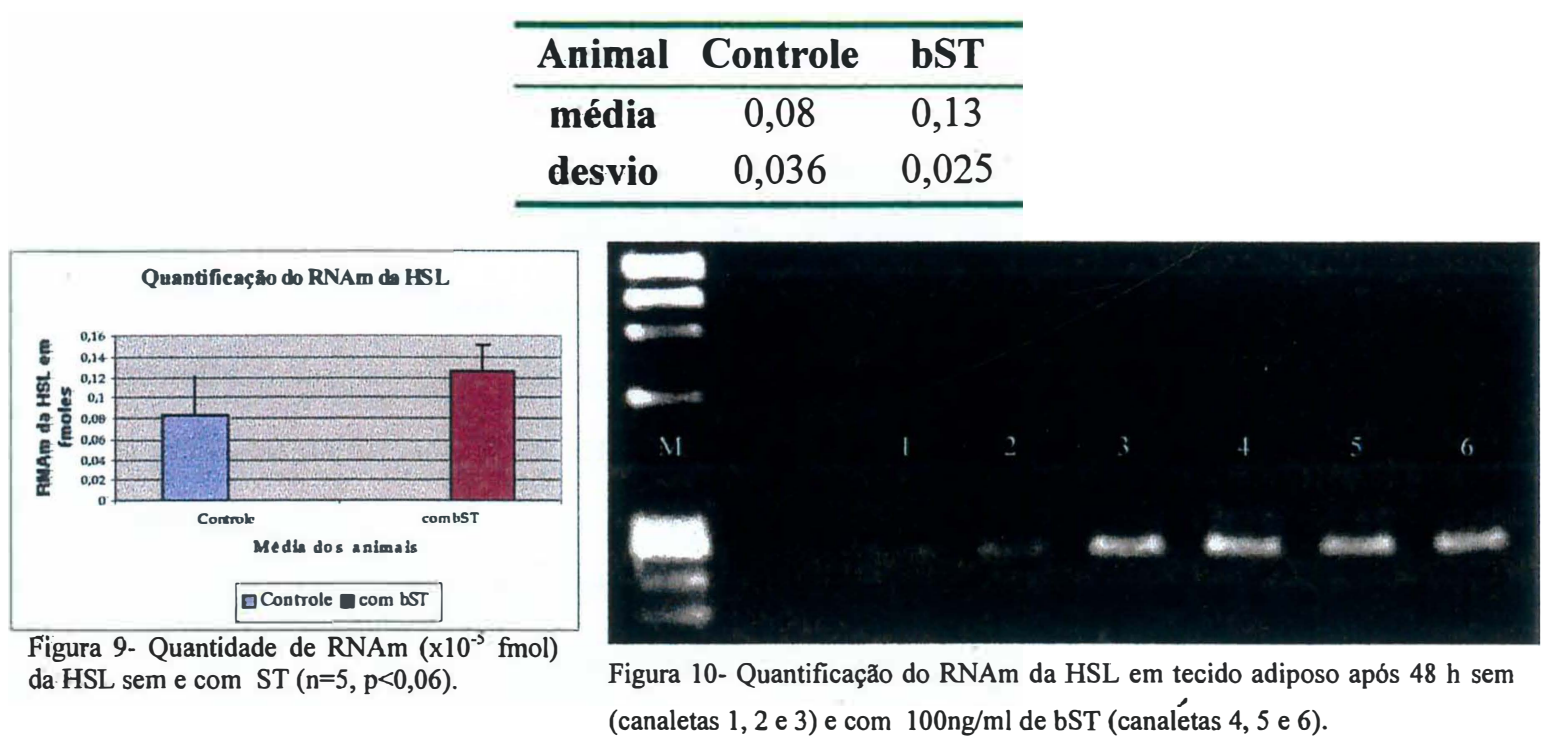

Pleé-Gautier et al. (1996) demosntraram in vitro que o AMPc reduzia a concentração de RNAm da HSL em células 3T3-F442A e BFC-1. Este resultado não era esperado pelos autores, e parece sugerir que se a ST aumenta a expressão da HSL, isto não deve acontecer através do aumento da concentração de AMPc. Ácidos graxos livres seriam potenciais candidatos, pois funcionariam como feedbacks negativos, evitando a depleção de reservas do animal.

A observação de um aumento no RNAm da $\operatorname{HSL}(n=5 ; p<0,06)$, sugere que a atividade da HSL não deva ser regulada exclusivamente por controle pós - traducionais, mas também pré - traducionais, suportando a hipótese de que o aumento na lipólise produzido pela ST possa ser função de alterações tanto na via que resulta na fosforilação da HSL (Lanna et al., 1995; Lanna \& Bauman, 1999), como também no aumento da quantidade desta enzima (Tabela 8). Estudos de Slavin et al., (1994), em culturas primárias de adipócitos de ratas tratados com hormônio do crescimento, glucagônio e epinefrina por 4 horas, embora a ST tenha sida capaz de promover a liberação de glicerol no meio, nenhum 
destes hormônios alterou a quantidade de RNAm da HSL. A dexametasona foi capaz de promover aumentos de cerca de 4 vezes nos níveis de RNAm da HSL (Slavin et al., 1994).

Sechen et al. (1989) observou um aumento de 6 vezes na liberação de NEFA após infusões com catecolaminas em vacas em lactação in vivo. Aparentemente, os resultados parecem sugerir que o notável aumento na lipólise em vacas tratadas com ST seja mais função das alterações na via de transmissão do sinal do AMPc do que exatamente pelos aumentos na expressão gênica (Tabela 8) ou atividade total da HSL (Dietz \& Schwartz, 1991; Lanna et al., 1995).

A lipólise é controlada por vias sinalizadoras estimulatórias e inibitórias e está rełacionada a concentrações intracelulares de AMPc (Fain \& Garcia-Sainz, 1993; Honnor et al., 1985), sendo o ponto inicial os receptores de membrana celular. Diversos trabalhos demonstram que o efeito maior da ST sobre o sistema de produção de AMPc estaria em uma redução na atividade da via inibitória controlando a lipólise (Lanna et al., 1995; Lanna \& Bauman, 1999).

Embora a ST tenha aumentado a lipólise, a atividade da HSL e a abundância do RNAm da HSL, não se observaram alterações $(n=5 ; p<0,10)$ nas quantidades de RNAm da

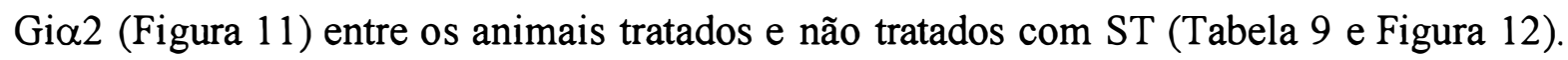
Concordando com estes resultados, Doris et al. (1996) e Houseknecht \& Bauman (1997) não observaram alteração da quantidade da proteína Gi 2 observada em tecido de ovinos e bovinos tratados cronicamente com ST, respectivamente. Entretanto em todos estes trabalhos houve uma redução na atividade da proteína $\mathrm{Gi}$.

Estas observações sugerem que a ST pode exercer seus efeitos alterando a habilidade da $\mathrm{Gi}$ em interagir com a adenilato ciclase, ou outro fator que altere sua funcionalidade (capacidade de se ligar ao GTP) e/ou sua distribuição, levando a uma maior associação com membranas de baixa densidade, como observado por Yip \& Goodman (1999). Já Doris et al. (1994), embora tenha observado um aumento na quantidade da

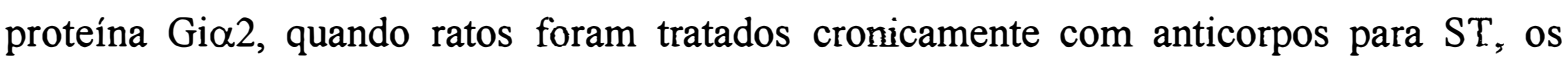
mesmos autores quando trataram ovelhas não lactantes com ST, não observaram alteração na expressão das proteínas Gi (Doris et al., 1996). As diferenças nos resultados destes dois trabalhos parecem ser explicadas por Yip \& Goodman (1999), que sugerem uma alteração na distribuição da proteína Gi na célula. 
Sabe-se que o receptor $A_{1}$ da adenosina que se acopla às proteínas $G$ inibitórias $e$ posteriormente à adenilato ciclase, não são alterados pela ST (Watt et al., 1991; Doris et al., 1996), reforçando a hipótese de que os efeitos são mediados por alterações na atividade da proteína Gi. Os resultados deste trabalho reforçam a hipótese de Yip \& Goodman (1999) de que o efeito não ocorre em nível de abundância da enzima.

Tabela 9: Quantificação em fmol do RNAm da proteína Gia2 sem e com ST $(\mathrm{p}>0,10)$.

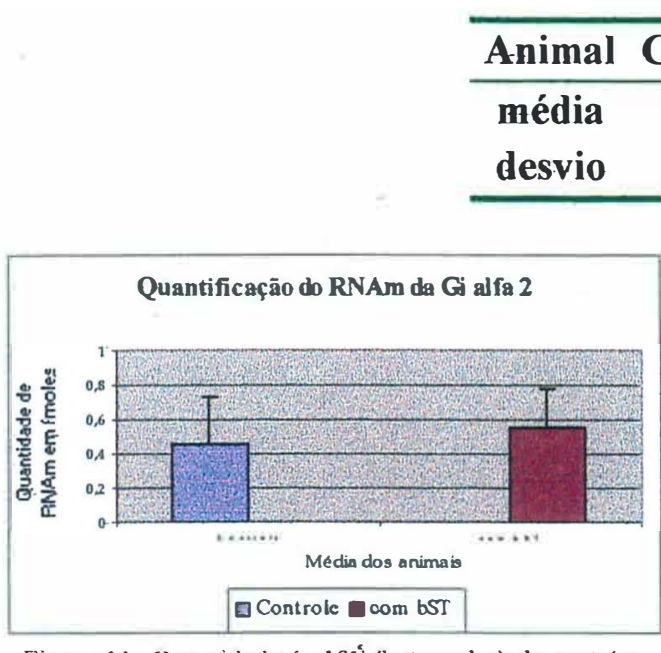

Figura 11- Quantidade (x 10-5 fentomoles) da proteina Gio 2 sem e com ST $(p>0,10)$.

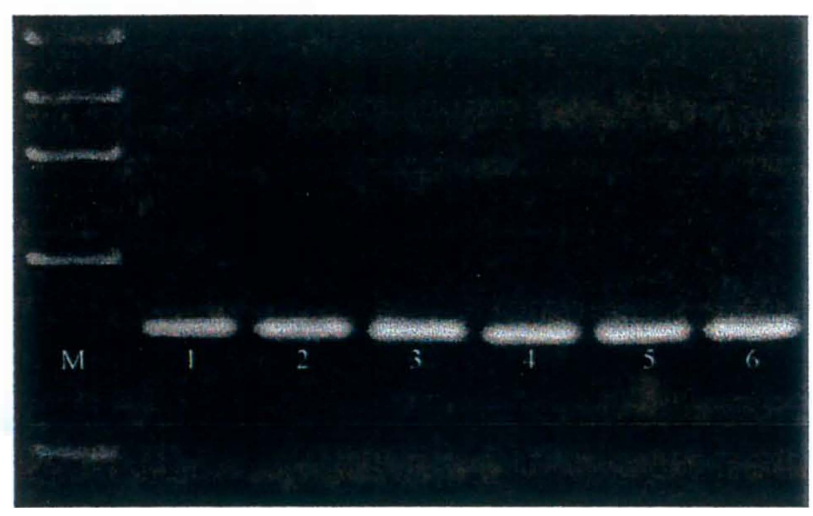

Figura 12- Quantificação do RNAm da Giळ2 em tecido adiposo incubado por $48 \mathrm{~h}$ sem (canaletas 1,2 c 3) e com $100 \mathrm{ng} / \mathrm{ml}$ de bST (canaletas 4.5 e 6 ).

Embora o tratamento com ST não altere a abundância da proteína Gi, modificações pós - traducionais das proteínas Gi são possíveis de explicar o aumento da lipólise, que seriam causados por alterações em sua funcionalidade (Houseknecth \& Bauman 1997; Roupas et al., 1991), ou-seja, a habilidade de sua subunidade $\alpha$ em interagir com a adenilato ciclase, e também a sua redistribuição em membranas subcelulares (Yip \& Goodman, 1999). A observância, neste trabalho, de um aumento na lipólise sem uma alteração na abundância da proteína Gi em explantes com e sem o tratamento com ST sưgerem alteração em sua funcionalidade. Infelizmente, não foi possível medir a quantidade de proteína Gi nestes explantes. 
Portanto, em vista destes resultados, outros mecanismos devem ser estudados para explicar a menor funcionalidade da proteína Gi. Alteração na distribuição sub-celular, fosforilação, miristolação e outras mudanças pós - tradução devem ser melhor investigadas. Novos trabalhos também devem procurar investigar a interação da HSL com a gota lipídica, procurando melhor definir a importância da abundância desta enzima. Estudos sobre a importância relativa da expressão gênica e da regulação da atividade das perilipinas devem ser conduzidos. 


\section{CONCLUSÃO}

O tratamento de longa duração com ST aumentou a concentração do RNAm da HSL nos explantes de tecido adiposo, resultados estes que concordam com outros trabalhos demonstrando maior atividade da enzima.

O tratamento com ST não alterou a abundância do RNAm da subunidade $\alpha$ da proteína $\mathrm{Gi}$, também consistente com dados de literatura. Estes resultados sugerem que a menor atividade da proteína Gi é função de uma menor funcionalidade, ou de alteração na sua localização sub celular, e não de uma alteração na sua expressão.

A metodologia de QC-RT-PCR ("quantitative-competitive", "reverse transcriptase", "polimerase-chain-reaction") foi utilizada com sucesso para a quantificação da abundância do RNAm dos genes da HSL e Gia2, utilizando a beta actina como padrão. A validação dessa metodologia para o tecido adiposo bovino e para genes estudados neste trabalho, permitiu, ao contrário da técnica de "Northern Blotting", trabalhar com quantidades limitadas de tecido. 


\section{REFERÊNCIAS BIBLIOGRÁFICAS}

AMATRUDA, T.T.; GAUTAM, III.; FONG, N.; NORTHUP, H.K.W.; SIMON, J.K. The 35- and 36-kDa beta subunits of GTP-binding regulatory proteins are products of separate genes. The Joumal of Biological Chemistry, v.263, p.5008-5011, 1988.

ARNER P.; ENGFELDT, P.; NOWAK, J. In vivo observations on the lipolytic effect of noradrenaline during therapeutic fasting. J. Clin. End. Met, v.53, p.1207-1212, 1981. (suppl 6).

ARNER, P.; KRIEGHOLM, E.; ENGFELDT, P; BOLINDER, J. Adrenergic regulation of lipolysis in situ at rest and during exercise. Journal of Clinical Investigation, v.85, p.893-898, 1990.

ARSHA VSKY, V.Y.; BOWNDS, M.D. Regulation of deactivation of photorecetor G protein byits target enzyme and cGMP. Nature, v.357, p.416-417, 1992.

ASANO, T; KATADA, T; GILMAN, A.G; ROSS, E.M. Activation of the inhibitory GTP-binding protein of adenylate cyclase, $\mathrm{Gi}$, by $\beta$-adrenergic receptors in reconstituited phospholipid vesicles. The Journal of Biological Chemistry, v.259, p.9351-9354, 1984.

ASDELL, S. A. The effect of the injection of hypophyseal extract in advanced lactation. American Jotrmad Physiolology, v.100, p.137-140, 1932.

BAUMAN, D. E.; PEEL, C.J.; STEINHOUR, W.D.; REYNOLDS, P.J.; TYRRELL, H.F.; BROWN, A.C G.; HAALAND, G.L. Effect of bovine somatotropin on metabolism of lactating dairy cows: influence on rates of irreversible loss and oxidation of glucose and nonesterified fatty acids. Joumal of Nutrition, v.118, p.1031, 1988.

BAUMAN, D.E. \& DAVIS, C.L. Regulation of lipid metabolism. In: Digestion and Metabolism in the ruminant. Eds: I.W. McDonald and A.C.I Wamer. Butterworths, London p.67-83, 1975.

BAUMAN, D.E. \& McCURTCHEON, S.N. The effects of growth hormone and prolactin on metabolism. In control of digestion and metabolism in ruminants. L.P. Milligan, W .L. Grovum and A. Dobson, editors. Prentice-Hall, Englewood Cliffs, N.J., p.436-455, 1986.

BAUMAN, D.E. \& VERNON, R.G. Effects of exogenous bovine somatotropin on lactation. Annual Review of Nutrition, v. 13, p.437-461, 1993.

BAUMAN, D.E.; DEGEETER, M.J.; PEEL, C.J.; LANZA, G.M.; GOREWIT, R.C.; HAMMOND, D.R.W Effect of recombinantly derived bovine growth hormone $(\mathrm{bGH})$ on lactational performance of high yiełding dairy cows. Joumal of Dairy Science, v. 65, p.121, 1982. (Suppl.1)/resumo.

BAUMAN, D.E.; MCCUTCHEON, S.N.; STEINHOUR, W.D.; EPPARD P.J.; SECHEN, S.J. Sources of variation and prospects for improvement of productive efficiency in the dairy cow: a review. Joumal of Animal Science, v. 60, p.583-592, 1985.

BAUMAN, D.E; DUNSHEA, F.R.; BOISCLAIR, Y.R; MCGUIRE, M.A.; HARRIS, D.M.; HOUSEKNECHT, K.L. Regulation of nutrient partitioning: homeostasis, homeorhesis and exogenous somatotropin. In Proceedings Seventh International Conference on Production Disease in Farm Animals. F. A. Kallfelz, editor. Comell Univ., Ithaca, NY, p. 306-323, 1989.

BEALS, C.R.; WILSON, C.B.; PERLMUTTER, R.M. A small multigene family encodes Gi signaltransduction proteins. Proceedings of the National Acadademy of Science of the USA, v.84, p.7886-7890, 1987. 
BEGIN-HEICK, N. Quantification of the $\alpha$ and $\beta$ subunits of the transducing elements (Gs and Gi) of adenylate cyclase in adipocyte membranes from lean and obese (ob/ob) mice. Biochemical Journal, v. 268, p. 83-89, 1990.

BELFRAGE, P. Hormonal control of lipid degradation. In: New Perspectives in Adipose Tissue: Structure, Function and Development. Eds. A. Cryer and R.L.R. Van, Butterwoths, London. p.121-144, 1984.

BELL, A.W.; BAUMAN, D.E; CURRIE, W.B. Regulation of nutrient partioning and metabolism during pre and postnatal growth. Journal of Animal Science, v.65, p.186-212, 1987 (suppl. 2).

BERRAONDO, B. \& MARTINEZ, J.A. Free fatty acids are involved in the inverse relationship between hormone-sensitive lipase (HSL) activity and expression in adipose tissue after high-fat feeding or beta3adrenergic stimulation. Obesity Research, v.8, nº 3, p.255-261, 2000.

BERNBAUMER, L.; ABRAMOWITZ, J; BROWN A.M. Receptor-effector coupling by G-proteins. Biochimica et Biophysica Acta, v.1031, p.163-224, 1990.

BONNET, M.; FAULCONNIER, Y; FLÉCHET, L.; HOCQUETTE, J-F; LEROUX, C.; LANGIN, D.; MARTIN, P.; CHILLIARD, Y. Messenger RNAs encoding lipoprotein lipase, fatty acid synthase and hormone-sensitive lipase in the adipose tissue of underfed-refed ewes and cows. Reprod. Nutr. Dev., v.38, p.297-307, 1998.

BOTION, L.M. \& GREEN, A. Long - term regulation of lipolysis and hormone-sensitive lipase by insulin and glucose. Diabetes, v.48, p.1691-1697, 1999.

BOUCHARD, C.; DEPRES, J.P.; MAURIEGE, P. Genetic and nongenetic determination of regional fat distribution. Endocrine reviews, v. 14, p.72-93, 1993.

BOUGNÉRES, P; STEENFF, C.; PECQUEUR, C; PINGHIR, E.; ADNOT, P.; RICQUIER, D. In vivo resistance of lipolysis to epinefrine. Journal of Clinical Investigation, v.99, p. 2568-2573, 1997.

BOWEN, W.P.; FLINT, D.J.; VERNON, R.G. Regional and interspecific differences in the ligand properties of the $\beta$-adrenergic receptors of individual white adipose tissue depots in the sheep and rat. Biochemical Pharmacology, v. 44, p. 681-686, 1992.

BOYD, R.D. \& BAUMAN, D.E. Mechanisms of action for somatotropin in growth. In Current Concepts of Animal Growth Regulation. D. R. Campion, G. J. Hausman, and R. J. Martin, editors. Plenum Publishing Corp., New York, p.257-293, 1989.

BOYD, R.D.; BAUMAN, D.E.; FOX, D.G.; SCANES, C.G. Impact of metabolism modifiers on protein accretion and protein and energy requirements of livestock. Journal of Animal Science, v.69, p.56-75, 1991. (Suppl. 2).

BRASAEMLE D.L.; BARBER T.; KIMMEL, A.R.; LONDOS, C. Post-translational regulation of perilipin expression: stabilization by stored intracellular neutral lipids. Journal of Biological Chemistry, v.272, n. 14, p.9378-9387, 1997.

BRASAEMLE, D. L.; LEVIN, D. M.; ADLER-WAILS, D. C.; LONDOS, C. The lipolytic stimulation of 3T3-L1 adipocytes promotes the translocation of cytosolic hormone-sensitive lipase to the surfaces of lipid storage droplets. Biochimica Biophysica Acta, v. 1483, p.251-262, 1999.

BRASAEMLE, D.L.; LEVIN, D.M.; ADLER-WAILES, D.C.; LONDOS, C. The lipolytic stimulation of 3T3-L1 adipocytes promotes the translocation of hormone-sensitive lipase to the surfaces of lipid storage droplets. Biochimica et Biophysica Acta, v.1483, p.251-262, 2000.

BROOK, J.D.; CURRACH, M.E.; HARLEY, H.G.; BUCKLER, A.J.; CHURCH, D.; ABURATANI, H; HUNTER, K.; STANTON, V.P.; HUDSON, T et al. Molecular basis of myotonic dystrophy. Cell, v. 68, p. 799-808, 1992. 
BUTCHER R.W. \& BAIRD.,C.E. Effects of prostaglandins on adenosine 3',5'-monophosphate levels in fat and other tissues. Joumal of Biological Chemistry, v.243, p.1713, 1968.

CAMPBELL, R.G.; JOHNSON, R.J.; TAVERNER, M.R.; KING, R.H. Interrelationships between exogenous porcine somatotropin administration and dietary protein and energy intake on protein deposition capacity and energy metabolism of pigs. Journal of Animal Science, v.69, p.1522-1531, 1991.

CARPENTIER, J.L.; PERRELET, A.; ORCI, L. Morphological changes of the adipose cell plasma membrane during lipolysis. Journal of Cell Biology, v.72, n.2, p.104-117, 1997.

CARTY, D.J.; PADRELL, E.; CODINA, J.; BIRNBAUMER, L.; HIDEBRANDT, J.D.; IYENGAR, R.J. Distint guanine nucleotide binding and release propertis of the tree Gi proteins. The Joumal of Biological Chemistry, v.265, p.6268-6273, 1990.

CERIONE, R.A.; REGAN, J.W.; NAKATA, H.; CODINS, J.; BENOVIC, J.L.;GIERSHIC, P.; SOMERS, R.L.; SPIEGEL, A.M.; BIRNBAUMER, L.; LEFCOWITZ, R.J.; CARON, M.G. Functional reconstitution of the $\alpha 2$-adrenergic receptor with guanine nucleotide regulatory proteins in phospholipid vesicles. The Journal of Biological Chemistry, v.261, p.3901-3909, 1996.

CHOHAN, P.; CARPENTER ,C.; SAGGERSON, E.D. Changes in the antilipolytic action and binding to plasma membranes of $\mathrm{N}^{6}$-phehylisopropyladenosine in adipocytes from starved and hypothyroid rats. Biochemical Journal, v.223, p.53-59, 1984.

CLIFFORD, G.M.; LONDOS, C.; KRAEMERI, F.B.; VERNON, R.G.; YEAMAN, S.J. Translocation of Hormone-sensitive Lipase and Perilipin upon Lipolytic Stimulation of Rat Adipocytes. The Journal of Biological Chemistry, v.275, no. 7, p.5011-5015, 2000.

COOPER, D. M. F.; SCHELL, J.M.; THORN, P.; IRVINE, F.P. Regulation of Adenylyl Cyclase by Membrane Potential. Journal of Biological Chemistry, v.273, p.27703-27707, 1998.

DALLE, S.; RICKETTS, W.; IMAMURA, T.; VOLLENWEIDER, P.; OLEFSKY, J.M. Insulin and IGF-I receptors utilize different $G$ protein signaling components. The Journal of Bioliogical Chemistry, jbc.M010884200, 2001. (no prelo).

DE VOS AM, ULTSCH M, KOSSIAKOFF AA. Human growth hormone and extracellular domain of its receptor: crystal structure of the complex. Science, v.255, p.306-312, 1992.

DEGERMAN, E.; LANDSTRÖM, T.R.; WIJKANDER, J.; HOLST, L.S.; AHMAD, F.; BELFRAGE, P.; MANGANIELLO, V. Phosphorylation and activation of hormone-sensitive lipase adipocyte phosphodiesterase type 3B. Methods in Enzymology, v.14, p.43-53, 1998.

DERMOT, M. F.; MICHAEL, C; SCHELL, J.; THORN, P.; IRVINE, R.F. Regulation of Adenylyl Cyclaseby Membrane Potential. The Journal of Biological Chemistry, v.273, p.27703-27707, 1998.

DÍAZ, E. \& PFEFFER, S.R. TIP47: A Cargo Selection Device for Mannose 6-Phosphate Receptor Trafficking. Cell, v.93, p. 433-443, 1998.

DIETZ, J. \& SCHWARTZ, J. Growth hormone alters lipolysis and hormone-sensitive lipase actvity in 3T3F442A adipocytes. Metabolism, v.10, issue8, p.800-806, 1991.

DOLE, V.P. A relation between non-esterified fatty acids in plasma and the metabolim of glucose. Journal of Clinical Investigation., v.35, p.150-154, 1956.

DORIS R.A.; THOMPSON, G.E.; FINLEY, E.; KILGOUR, E., HOUSLAY, M.D; VERNON, R.G. Chronic effects of somatotropin treatment on response of subcutaneous adipose tissue lipolysis to acutely acting factors in vivo and in vitro. Journal of Animal Science, v.74, p.562-568, 1997. 
DORIS, R. A.; THOMPSON, G.E.; FINLEY, E.; KILGOUR, E.; HOUSLAY, M.D.; VERNON, R.G. Chronic effects of somatotropin treatment on response of subcutaneous adipose tissue lipolysis to acutely acting factors in vivo and in vitro. Journal of Animal Science, v.74, p. 562-568, 1996.

DORIS, R. A.; VERNON, R.G.; HOUSLAY, M.D. AND KILGOUR, E. Gorwth hormone decreases the response to antilipolytic agonists and decreases the levels of Gi2 in rat adipocytes. Biochemical Journal, v.297, p.41-45, 1994.

DORIS, R.A.; KILGOUR, E.; HOUSLAY, M.D.; VERNON, R.G. Regulation of the GTP-binding proteinbased antilipolytic system of sheep adipocytes by grwth hormone. Journal of Endocrinology, v.158, p.295-303, 1998.

DUNSHEA, F.R.; HARRIS, D.M.; BAUMAN, D.E.; BOYD, R.D. AND BELL A.W. Effect of porcine somatotropin on in vivo glucose kinetics and lipogenesis in growing pigs. Lournal of Animal Science, v.70, p. 141-146, 1992.

ETHERTON, T.D. \& SMITH, S.B. Somatotropin and B-adrenergic agonists: their efficacy and mechanisms of action. Journal of Animal Science, v.69, p.2-26, 1991. (Suppl. 2).

EVANS, T.; FAWZI, A.; FRASER, E.D.; BROWN, M.L.; NORTHUP, J.K. Purification of a beta 35 form of the beta gamma complex common to G- proteins from human placental membranes. The Journal of Biological Chemistry, v.262, p.176-181, 1987.

EVANS, H.M. \& LONG, J.A. Characteristic effects upon growth, oestrus and ovulation induced by the intraperitoneal administration of fresh anterior hypophyseal substance. Proceedings of the National Academy of Science, USA, v. 8, 38-39, 1921.

EVORA, P.R.B. \& NOBRE, F. O Papel das G-Proteinas na fisiopatologia das Doenças Cardiovasculares. Gproteinas na fisiopatologia cardiovascular. Arquivo Brasileiro de Cardiologia, v.72, n² 2, 1999.

FAIN, J.N. \& GARCIA-SAINZ, J.A. Adrenergic regulation of adipocyte metabolism. Joumal of Lipid Research, v.24, p.945-966, 1983.

FOLEY, K.P.; LEONARD, M.W.; ENGEL, J.D. Quantitation of RNA using the polimerase chain reaction. TIG, v.9, issue 11, p.380-385, 1993.

FOSTER, C.M.; HALE, P.M.; JING, H.W.; SCHWARTZ, J. Effects of human growth hormone on insulinestimulated glucose metabolism in 3T3-F442A adipocytes. Endocrinology, v.123, issue 2, p.10821088,1988

FRANKE, W.W.; HERGT, M.; GRUND, C. Rearrangement of the vimentin cytoskeleton during adipose conversion: formation of an intermediate filament cage around lipid globules. Cell, v.49, p.131-141, 1987.

FRAYN, K.N.; COPPACK, S.W.; FIELDING, B A. E HUMPHREYS, S.M. Coordinated regulation of hormonesensitive lipase and lipoprotein lipase in human adipose tissue in vivo: implications for the controlof fat storage and fat mobilization. Advances in Enzyme Regulation, v. 35, p.163-178, 1995.

FREDRIKSON, G.; STRALFORS, P.; NILSSON, N.O.; BELFRAGE, P. Hormone-sensitive lipase of rat adipose tissue. The journal of Biological Chemistry, v.256, issue 12, p.6311-6320, 1981.

FROHLI, D.M. \& BLUM, J.W. Nonesterified fatty acids and glucose in lactating dairy cows: diurnal variations and changes in responsiveness during fasting to epinephrine and effects of beta-adrenergic blockade. Journal of Dairy Science, v.71, p.1170-1177, 1988. 
FUJII, J; OTSU, K; ZORZATO, F; DE LEON, S.; KHANNA, V. K.; WELLER, J.E.; O'BRIEN, P.J.; MCLENNAN, D.H. Identification of a mutation in porcine ryanodine receptora associated with malignant hyperthermia. Science, v.253, p.448-451, 1991.

GARTON, A.J.; CAMPBELL, D.G.; CARLING, D.; HARDIE, D.G.; COLBRAN, RJ.; YEAMAN, S.J. Phosphorylation of bovine hormone-sensitive lipase by AMP-activated protein kinase. A possible antilipolytic mechanism. European Journal of Biochemistry, v.179, p.249-254, 1989.

GARTON, A.J.; CAMPBELL, D.G.; COHEN, P; YEAMAN, S.J. FEBS Letters, v. 229, p.68-72, 1988.

GASIC, S.; TIAN, B.; GREEN, A. Tumor Necrosis Factor a Stimulates Lipolysis in adipocytes by Decreasing Gi Protein Concentrations. The Journal of Biological Chemistry, v.274, no.10, p.6770-6775, 1999.

GLMAN, A.G. G proteins: transducers of receptor-generated signals. Annual Ver. Biochem. v.56, p.615, 1987.

GORDON, S. R. JR \& CHERKER, A. Unesterified fatty acids in human blood plasma. Journal of Clinical Investigation, v.35, p.206-212, 1956.

GORIS, R. A.; THOMPSON, G.E.; FINLEY, E.;KILGOUR, E.; HOUSLAY, M.D. AND VERNON, R.G. Chronic effects of somatotropin treatment on response of subcutaneous adipose tissue lipolysis to acutely acting factors in vivo and in vitro. Journal of Animal Science, v.74, p.562-568, 1996.

GORNAL, H. G.; BARDIWELL, C. J.; RAO, P. N. Determination of serum protein by means of the biuret reaction. Journal Biological Chemistry, v.177, p.751-766, 1949.

GREENBERG, A.; EGAN, J.J.; WEK, S.A.; GARTY, N.B.; BLANCHETTE-MACKIE, E.J. ; LONDOS, C. Perilipin, a major hormonally regulated adipocyte-specific phosphoprotein associated with the periphery of lipd storage droplets. Journal of Bological Chemistry, v.266, p.11341-11346, 1991.

GREENBERG, A.S.; EGAN, J.J.; WEK, S.A.; MOOS, M.C. JR; LONDOS, C.; KIMMEL, A.R. Isolation of cDNAs for Perilipins A and B: Sequence and Expression of Lipid Droplet-Associated Proteins of Adipocytes. PNAS, v..90, p.12035-12039, 1993.

GROBER, J.; LAURELL, H.; BLAISE, R.; FABRY, B.; SCHAAK, S.; HOLM, C. Characterization of the promoter of human adipocyte HSL. Biochemical Journal, v.328, p.453-461, 1997.

GU, F.; HARBITZ, I.; CHOWDHARY, B.P.; BOSNES, M.; GUSTAVSSON, I. Chromossomal localizationof the hormone-sensitive lipase (LIPE) and insulin receptor (INSR) genes in pigs. Hereditas, v.117, p.231-236, 1992.

GUTKIND, J.S. The pathways connecting G protein-coupled receptors to the nucleus through divergent mitogen-activated protein kinase cascades. The Journal of Biological Chemistry, v.273, no4, issue 23, p.1839-1842, 1998.

HALLAC, H.; BRASS, L.F.; MANNING, D.R. Failure to myristoylate the alpha subunit of Gz is correlated with an inhibition of palmitoylation and membrane attachment, but has no affect on phosphorylation by protein kinase C Journal of Biological Chemistry, v.269, p.4571-4576, 1993.

HAMM, H.E. The many faces of G protein signaling. The journal of Biological Chemistry, v.273, no 2, issue 9, p.669-672, 1998.

HARDIE, D. \& MCINTOSH, R. AMP-activated protein kinase: na archetypal protein kinase cascate. BioEssays, v. 14, p.699-704, 1992. 
MARTIN-HIDALGO, A.; HOLM, C.; BELFRAGE, P.; SCHOTZ, M. C.; HERRERA, E. Lipoprotein lipase and hormone-sensitive lipase activity and $\mathrm{mRNA}$ in rat adipose tissue during pregnancy. American Journal of Physiology, v.266, p.E930-E935, 1994.

HIGGNS, J.B. \& CASEY, P.J. In vitro processing of recombinant G protein gamma subunits. Requirements for assembly of an active beta gamma complex Journal of Biological Chemistry, v.269, p.9067-9073, 1994.

HITTELMAN, K.J.; WU, C.F.; BUTCHER, R.W. Control of cyclic AMP levels in isolated fat cells from hamsters. Biochimica at Biophysica Acta, v.304, p. 188-196, 1976.

HO, R.J. \& MENG, H.C. Technique for the cannulation and perfusion of isolated rat epididymal fat pad. Journal of Lipid research, v.5, p.203-210, 1964.

HOFFMAN, B.B.; CHANG, H.; REAVEN, G.M. Stimulation and inhibition of lipolysis in isolated rat adipocytes: Evidence for age-related changes in responses to forskolin and PGE1. Hormone Metabolism Research, v.19, p.358-60, 1987.

HOLM, C.; BELFRAGE, P.; FREDRIKSON, G. Immunological evidence for the presence of hormone-sensitive lipase in rat tissues other than adipose tissue. Biochemical and Biophysical Research Communications, v.148, p.99-105, 1987.

HOLM, C.; KICHGESSNER, T. G.; SVENSSON, K.L.; FREDRIKSON, G; NILSSON, S.; MILLER, C.G. SHIVELY, J.E.; HEINZMANN, C.; SPARKES, RS.; MOHANDAS, T; LUSIS, A. J.; BELFRAGE, P; SHOTZ, M.C. Hormone-sensitive lipase: sequence, expression and chromossomal localization to 19 cent q13.3. Science, v.241, p.1503-1506, 1988.

HOLST, S.L.; HOFFMANN, A..M.; MULDER, H.; SUNDLER, F.; HOLM, C.; BERGH, A.; FREDRIKSON, G. Localization of hormone-sensitive lipase to rat Sertoli cells and its expression in developing and degenerating testes. FEBS Letters, v.355, p.125-30, 1994.

HOLST, L.S.; LANGIN, D.; MULDER, H.; LAURELL, H.; GROBER, J.; BERGH, A.; MOHRENWEISER, H.W.; EDGREN, G.; HOLM, C. Molecular cloning, genomic organization and expresion of testicular isoform of hormone-sensitive lipase. Genomics, v.35, p.441-447,1996.

HONNOR, R. C.; DHILLON, G. S.; LONDOS, C. cAMP-dependent protein kinase and lipolysis in rat adipocytes. II. Definition of steady-state relationship with lipolytic and antilipolytic modulators. Journal of Biological Chemisty, v.260, p.15130-15145, 1985.

HOUSEKNECHT, K.L. \& BAUMAN, D.E. Regulation of lipolysis by somatotropin: functional alteration of adrenergic and adenosine signaling in bovine adipose tissue. Journal of Endocrinology, v.152, p.465-475, 1997.

HOVE, K. \& BLOM, K. Plasma insulin and growth hormone in dairy cows; diurnal variation and relation to food intake and plasma sugar and acetoacetate levels. Acta Endocrinolology, v.73, p.289-303, 1973.

HUI, D.Y. Biochimica et Biophysica acta, v.1303, p.1-14, 1996.

ILIOU, J. \& DEMARNE, Y. Evolution of the sensitivity of isolated adipocytes of ewes to the antilipolytic action of adenosine during pregnancy and lactation. Comp. Biochem. Physiol., v.86A, p.755, 1987.

ITOH, H.; TOYAMA, R.; KOZASA, T.; TSUKAMOTO, T.; MATSUOKA, M.; KAZIRO, Y. Presence of three distinct molecular species of Gi protein alpha subunit. Structure of rat cDNAs and human genomic DNAs. The Journal of Bioliogical Chemistry, v.263, n¹4, p.6656-6664, 1988.

JEPSON, S. A. \& YEAMAN, S.J. Inhibition of hormone-sensitive lipase by intermediary lipid metabolites. FEBS Letters, v.310, p.197-200, 1992. 
KAHN, B. Facilitative glucose transporter: regulatory mechanisms and dysregulation in diabetes. Journal of Clinical Investigation, v. 89, p. 1367-1374, 1992.

KAKLBRENNER, F.; DIPPEL, E.; WITTING, B AND SCHULTZ, G. Specificity of interation between receptor and $G$ protein: use of antisense techniques to realte G- protein subunits to function. Biochimica et Biophysica Acta, v.1314, p.125-139, 1996.

KERBER, J.A.; WRAY-CAHEN, D.; BOYD, R.D.; BAUMAN, D.E. Decreased glucose response to insulin is maximal within 24 hours of omatotropin injection in growing pigs. domestic animal endocrinology, v.15, issue 14, p.267-270, 1998.

KISSEBAH, A.H.; VYDELINGUM, N; MURRAY, R.; EVANS, D.J.; HATRZ, A.J.; KALKHOFF, R.K. AND ADAMS P.W. Relation of body fat distribution to metabolic complications of obesity. J. Clin. Endocrinol. Metabol., v.54, p.254-260, 1982.

KOCH, C.A.; ANDRESON, D.; MORAN, M.F.; ELLIS, C. AND PAWSON, T. SH2 and SH3 domains: elements that control interactions of cytoplasmic signaling proteins. The Journal of Biological Chemistry, v.259, p.832-834, 1991.

KOTAKE, S.; SCHUMACHER, H.R.; WILDER, R.L. A simple nested RT-PCR method for quantitation of the relative amounts of multiple cytokine mRNAs in small tissue samples. Journal of Immunological Methods, v.199, p.193-203, 1996.

KRAEMER, F.B.; TAVANGER, K.; HOFFMAN, A.R. Developmental regulation of hormone-sensitive lipase mRNA in the rat: changes in steroidogenic tissues. Journal of Lipid Research, v.32, p. 1303-1310, 1991.

LAI, E.; ROSEN, O.M.; RUBIN, C.S. Differentiation-dependent expression of catecholamine-stimulated adenylate cyclase. The Journal of Biological Chemistry, v.256, no 25, p.12866-12874, 1981.

LANGFORT, J.; PLOUG T.; IHLEMANN J.; SALDO M.; HOLM C.; GALBO H. Expression of hormonesensitive lipase and its regulation by adrenaline in skeletal muscle. Biochemical Journal, v.340, p.459$465,1999$.

LANGFORT, J.; PLOUG, T.; IHLEMANN, J.; HOLM, C.; GALBO, H. Stimulation of hormone-sensitive lipase activity by contractions in rat skeletal muscle. Biochemical Journal, v.351, p.207-214, 2000.

LANGIN, D ; LAURELL, H; HOLST, L.S.; BELFRAGE, P.; HOLM, C. Gene organization and primary structure of human hormone-sensitive lipase: possible significance of a sequence homology with a lipase of Moraxella TA144, na antartic bacterium. Porceedings of the National Academy of Sciences, USA, v, 90 , p.4897-4901, 1993.

LANGIN, D. \& HOLM, C. Sequence similarities between hormone-sensitive lipase and five prokaryotic enzymes. Trends in Bioquemical Sciences, v. 18, p.466-467, 1993

LANGIN, D.; HOLM, C.; LAFONTAN, M. Adipocyte HSL: a major regulator of lipid metabolism. Proceedings of the Nutrition Society, v.55, p. 93-109, 1996.

LANNA, D.P.D. \& BAUMAN, D.E. Effect of Somatotropin, insulin and glucocorticoid on lipolysis in chronic cultures of adipose tissue from lactating cows. Journal of Dairy Science, v.82, p.60-68, 1999.

LANNA, D.P.D.; DWYER D.A.; BAUMAN, D.E. Effect of Somatotropin on Lipolysis and Response to Homeostatic Signals in Chronic Cultures of Lactating Cow Adipose Tissue. Journal of Animal Science v.72, p.209, 1994a. (suppl. 1). 
LANNA, D.P.D.; HOUSEKNECHT, K.L.; HARRIS, D.M; BAUMAN, D.E. Effects of Somatotropin Treatment on Lipogenesis, Lipolysis and Related Cellular Mechanisms in Adipose Tissue of Lactating Cows. Joumal of Dairy Science, v.78, p.1703-1712. 1995b. (suppl. 8).

LARGE V.; REYNISDOTTIR S.; LANGIN D.; FREDBY K.; KLANNEMARK M.; HOLM C.; ARNER P. Decreased expression and function of adipocyte hormone-sensitive lipase in subcutaneous fat cells of obese subjects. Journal of Lipid Research, v.40, p.2059-2065, 1999.

LARSEN, J.L. Human growth hormone enhances pertussis toxin-stimulated ADP-ribosylation of Gi in Nb2 cell membrane. Journal of Biological Chemistry, v.267, p. 10583-10587, 1992. (supp15)

LAURIN, N.N.; WANG, S.P.; MITCHELL, G.A. The hormone-sensitive lipase gene is transcribed from at least five alternative first exons in mouse adipose tissue. Mammal Genome, v.11, n 11, p.972-978, 2000.

LAVAN, B. E.; FANTIN, V. R.; CHANG, E. T.; LANE, W. S.; KELLER, S. R.; LIENHARD, G. E. A Novel $160-k D a$ Phosphotyrosine Protein in Insulin-treated Embryonic Kidney Cells Is a New Member of the Insulin Receptor Substrate Family. The Journal of Biological Chemistry, v.272, p.21403-21407, 1997.

LAVAN, B. E.; LANE, W. S.; LIENHARD, G. E.; Lienhard, G.E. The 60-kDa phosphotiyrosine protein in insulin-treated adipocytes is a new member of the insulin receptor substrate family. The Journal of Biological Chemistry, v.272, p.11439-11443, 1997.

LEE, B.K. \& CROOKER, B.A.; Partial sequence and polymorphisms in the bovine hormone sensitive lipase (bHSL) gene. Genebank, accession U78042. Submitted 13/11/96 Animal Science, University of Minnesota, 1364 Eckles Ave, St. Paul, MN 55108, USA. 1996.

LEE, M.O. \& SCHAFFER, N.K. Anterior pituitary growth hormone and the composition of growth. Journal of Nutrition, v.7, p.337-363, 1934.

LEFKOWITZ, R.J. \& CARON, M.G. Adrenergic receptors. Models for the study of receptors coupled to guanine nucleotide regulatory proteins. The Journal of Biological Chemistry, v.263, p.4993-4996, 1988.

LEVITT, R.; LIU, Z.; NOURI, N.; MEYERS, D.; BRANDRIFF, B.; MOHRENWIESER, H Mapping of the gene for hormone-sensitive lipase (LIPE) to chromossome 19q13.1-13.2. Cytogenetics and Cell Genetics, v.69, p.211-214, 1995.

LI-NA WEI. Transgenic Animals As New Approaches In Pharmacological Studies. Annual Review of Pharmacology and Toxicology, v.37, p.119-141, 1997.

LINDER, M.E.; EWALD, D.A.; MILLER, R.J.; GILMAN, A.G. Purification and characterizzation of Goa and three types of Gia after expresion in Echerichia coli. The Journal of Biological Chemistry, v:265, p.8243-8521, 1990.

LONDOS, C; SALOMON, Y; LIN, M.C.; HARWOOD, J.P.; SCHRAMIM, M.; WOLFF, J.; RODBELL, M. 5'-guanylylimidiphosphate, a potent activator of adenylate cyclase systems in eukaryotic cells. Proceedings of the National Academy of Science. USA, v. 71, no. 8, p.3087-3090, 1974.

LONDOS, C.; BRASAEMLE, D.L.; SCHULTZ, C.J.; SEGREST, J.P.; KIMMEL, A.R. Perilipins, ADRP, and other proteins that associate with intracellular neutral lipid droplets in animal cells. Seminars in Cell and Developmental Biology, v. 10, p.51-58, 1999.

LOUNSBURY, K.M.; CASEY, P.J.; BRASS, L.F.; MANNING, D. R. Phosphorilation of Gz in human platelets: selectivity and site of modification. The Journal of Biological Chemistry, v.266, p.22051-22056, 1991. 
MCCUTCHEON, S.N.\& BAUMAN, D.E. Effect of chronic growth hormone treatment on responses to epinephrine and thyrotropin-releasing hormone in lactating cows. Journal of Dairy Science, p.69-44, 1986.

MCGUIRE, A.; DWYER, D.A.; BAUMAN, D.E.; SMITH, D.F. Insulin-Like Growth Factors in Plasma and Afferent Mammary Lymph of Lactating Cows Deprived of Feed or Treated with Bovine Somatotropin . Journal of Dairy Science, v.81, p.950-957, 1998.

MCNAMARA, J.P. \& HILLERS, J.K. Regulation of bovine adipose tissue metabolism during lactation.1. Lipid synthesis in response to increased milk production and decreased energy intake. Joumal of.Dairy Science v.69, p.3032-3041, 1986.

MCNAMARA, J.P.; DOUGLAS, C. M. AND BAI, S. Regulation of bovine adipose tissue metabolism during lactation. 3. Adaptations of hormne-sensitive lipase and lipoprotein lipases. Journal of Dairy Science, v.70, p.1377-1384, 1987.

MITCHELL, F.I.; GRIFFITHS, S. L.; SAGGERSON, E. D.; HOUSLAY, M.D.; KNOWLER, J.T. AND MILLIGAN, G. Guanine-nucleotide-binding proteins expressed in rat white adipose tissue. Biochemical Journal, v.262, p.403-408, 1989.

MORIMOTO, C.; KAMEDA, K.; TSUJTA, T.; OKUDA, H. Relationships between lipolysis induced by various lipolytic agents and hormone-sensitive lipase in rat fat cells. Journal of Lipid Research, v. $42, n^{\circ} 1$, p.120-127, 2001.

MORIMOTO, C.; TSUJITA, T.; OKUDA, H. Norepinephrine-induced lipolysis in rat fat cells from visceral and subcutaneous sites: role of hormone-sensitive lipase and lipid droplets. Journal of Lipid Research, v.38, p.132, 1997.

MORIMOTO, C.; TSUJITA, T.; SUMIDA, M.; OKUDA, H. Substrate-dependent lipolysis induced by isoproterenol. Biochemical and Biophysical Research Communications, v.274, nº 3, p.631-634, 2000.

MOSELEY, W.M.; PAULISSEN, J.B.; GOODWIN, M.C.; ALANIZ G.R.; CLAFIN, W.H. Recombinant bovine somatotropin improves growth performance in finishing beef steers. Journal of Animal Science, v.70, p.412425, 1992. (suppl 2).

MYUNG, C-S.; YASUDA, H.; LIU, W.; HARDEN, T.K.; GARRISON, J.C. Role of Isoprenoid Lipids on the Heterotrimeric G Protein $g$ Subunit in Determining Effector Activation. Joumal of Biological Chemistry, v.274, p.16595-16603, 1999.

NEER, E. J. Heterotrimeric G proteins: Organizers of transmembrane signals. Cell, v.80, p.249-257, 1995.

NILSSON, N.O.; STRALFORS, P.; FREDRIKSON, G.; BELFRAGE, P. Regulation of adipose tissue lipolysis:effects of noradrenaline and insulin on phosphorylation of hormone-sensitive lipase and on lipolysis in intact rat adipocytes. FEBS Letters, v.111, p.125-130, 1980.

NUKADA, T.; TANABE, T.; TAKAHASHI, H.; NODA, M.; HIROSE, T.; INAYAMA, S.; NUMA, S. Primary structure of the $\alpha$-subunit of bovine adenylate cyclase-stimulating G-protein deduced from the cDNA sequence. FEBS Letters, v.195, p.220-224, 1986.

OKUDA, H.; Y ANAGI I.; FUJII, S. the mechanism of in vitro stimulation of lipolysis by adrenaline. Journal of. Biochemistry, v.59, p.438-442, 1966.

OLSSON, H. \& BELFRAGE, P. Phosphorylation and dephosphorylation of hormone-sensitive lipase. Interactions between the regulatory and basal phosphorylaiton sites. FEBS Letters, v.232, p.78-82, 1988. 
OLSSON, H. \& BELFRAGE, P. The regulatory and basal phosphorilation sites of hormone-sensitive lipase are dephosphorilated by protein phosphatase-1, $2 \mathrm{~A}$ and $2 \mathrm{C}$ but not by protein phosphatase-2B. European Journal of biochemistry, v. 168, p.399-405, 1987.

ORO, L.; ROSELL, S; WALLENBERG, L. Circulatory and metabolic processes in adipose tissue in vivo. Nature, v.205, p. 178-179, 1965.

OSUGA, J.I.; OKA, S.I.T.; YAGYU, H.; TOZAWA, R.; FUJIMOTO, A.; SHIONOIRI, F.; YAHAGI, N.; KRAEMER, F.B.; TSUTSUMI, O.; YAMADA, N. Targeted disruption of hormone-sensitive lipase results in male sterility and adipocyte hypertrophy, but not in obesity. Medical Sciences, v.97, p.787-792, 2000.

PATTI, M.-E.; SUN, X.-J.; BRUENING, J. C.; ARAKI, E.; LIPES, M. A.; WHITE, M. F.; KAHN, C. R. 4PS/insulin receptor substrate (IRS)-2 is the alternative substrate of the insulin receptor in IRS-1deficience mice. The Journal of Biological Chemistry, v. 270, p.24670-24673, 1995.

PATTON, J.; SHEPARD, H.; WILKING, H.; LEWIS, G.; AGGARWAL, B.; EESSALU, T.; GAVIN, L; GRUNFELD, C. Interferons and tumor necrosis factors have a similar catabolic effects on 3T3 L1 cells. Proceedings of the National Academy of Sciences, USA, v.83, p.8313-8317, 1986.

PLEÉ-GAUTIER, E.; GROBER, J.; DUPLUS, E.; LANGIN, D.; FOREST, C. Inhibition of HSL gene expresison by AMPc and phorbolo esters in 3T3-F442A and BFC-1 adipocytes. Biochemical Joumal, v.318, p. 1057-1063, 1996.

POHL, S.L.; BIRNBAUMER, L.; RODBELL, M. The glucagon-sensitive adenyl cyclase system in plasma membrane of rat liver. The Journal of Biological Chemistry, v. 246, nº, p. 1819-1856, 1971.

RADCLIFF, R. P.; VANDEHAAR, M. J;. SKIDMORE, A. L; CHAPIN, L. T.;. RADKE, B. R;. LOYD, J. W; STANISIEWSKI, E. P.;. TUCKER, H. A. Effects of Diet and Bovine Somatotropin on Heifer Growthand Mammary Development. Joumal of Dairy Science, v.80, p.1996-2003, 1997.

RAHN, T.; RIDDERSTRALE, M; TORNQVIST, H.; MANGANIELLO, V; FREDRIKSON, G.; BELFRAGE, P.; DEGERMAN, E. Essencial role of phosphatidylinositol 3-kinase in insulin-induced activation and phosphorylation of the CGMP-inhibited cAMP phosphodiesterase in rat adipocytes. FEBS Letters, v.350, p.314-318, 1994.

REBUFFÉ-SCRIVE, M; LONNROTH, P; MARIN, P.; WESSLAU, C.; BJORNTORP, P.; SMITH, U. Regional adipose tissue metabolism in men and postmenopausal women. International Joumal of Obesity, v.11, p.347-355, 1987.

REUE, K. mRNA quantitation techniques: Considerations for experimental design and application. Journal of Nutrition, v.128, p.2038-2044, 1998.

REYNISDOTTIR, S.; WAHRENBERG, H.; CARLSTRON, K.; ROSSNER, S.; ARNER, P. Catecholaminesresistance in fat cells of upper-body obese womwn due to decrease expression of beta 2-adrenoreptors. Diabetologia, v. 37, p. 423-425, 1994.

RODAN, S.B. \& RODAN, G.A. Dexamethasone effects on b-adrenergic receptors and adenylate cyclase regulatory proteins Gs and Gi in ROS 17/2.8 cells. Endocrinology, v. 118, issue 6, p:2510-2518, 1986.

RODBELL, M. Mechanisms of receptor regulation. Ed. George Poste and Stanley T. Crooke, cap 5, p.65-73, 1985.

RODBELL, M. Metabolism of isolated fat cells. I-Effects of hormones on glucose metabolism and lipolysis. The Journal of Biological Chemistry, v.239, p.375-380, 1964. 
RODBELL, M.; BIRNBAUMER, L.; POHL, S.; KRANS, H.M.J. The Glucagon-sen\&ive Adenyl Cyclase System in Plasma Membranes of Rat Liver. The Biological Chemistry, v.248, p. 1877-1888, 1971.

ROOF, D.J.; APLLEBURY, M.L.; STERWEISS, O.C. Relationships whithin the family of GTP-m binding proteins isolated from bovine central nervous system. The Journal of Biological Chemistry, v.260, p.16242-16249. 1995.

ROSELL, S. \& BELFRAGE, E. Blood circulation in adipose tissue. Physiological Revies, v.59, no 4, p.10781104, 1979.

ROUPAS, P.; CHOUS, S. Y. TOWNS, R.J.; KOSTYO, J.L. Growth hormone inhibits activation of phosphatidylinositol phospholipase $\mathrm{C}$ in adipose membranes: evidence for a a growth hormone-induced change in G protein function. Proceedings of the National Academy of Sciences of the USA, v.88, p.1691-1695, 1991.

RUDOLPH, U.; SPICHER, K; BIRNBAUMER, L. Adenylyl cyclase inhibition and altered g protein subunit expression adn Adp-ribosylation patterns in tissues and cells from Gi2 $\alpha-/$-mice. Proceedings of the National Academy of Science of the USA, v.93, p.3209-3214, 1996.

SAMBROOK, J.; FRITCH, E.F.; MANIATIS, T. A laboratory manual, 2 edn. Cold Spring Laboratory Press, Cold Spring Harbor, 1989.

SECHEN, S.J.; BAUMAN, D.E.; TYRRELL, H.F.; REYNOLDS, P.J. Effect of somatotropin on kinetics of nonesterified fatty acids and partition of energy, carbon, and nitrogen in lactating dairy cows. Joumal of Dairy Science, v.72, p.59-67, 1989.

SERVETNICK, D.A.; BRASAEMLE, D.L.; GRUIA-GRAY, J.; KIM-MEL, A.R.; WOLi, J.; LONDOS, C. Perilipins are associated with cho-lesteryl ester droplets in steroidogenic adrenal cortical and Leydig cells. The Journal of Biological Chemistry, v.270, p.16970-16973, 1995.

SMITH, T.R. \& MCNAMARA, J P. Regulation of bovine adipose tissue metabolism during lactation. 6. Cellularity and hormone-sensitive lipase activity as affected by genetic merit and energy intake. Journal of Dairy Science, v.73, p.772-783, 1990.

STEPHEN, I; BIRNBAUMER, P.J.; RODBELL, M. The Glucagon-sensitive Adenyl Cyclase System in Plasma Membranes of Rat Liver. The Journal of Biological Chemistry, v.216, p.1819-1856, 1971.

STRALFORS, P.; BLORELL, P; BELFRAGE, P. Proceedings of the National Academy of Science USA, v.81, p.3317-3321, 1984.

STRALFORS, P \& BELFRAGE, P. Phosphorylation of hormone-sensitive lipase by cyclic AMP- dependent protein kinase. Joumal of Biological Chemistry, v.258, p.13385-13390, 1983.

STRASSHEIM, D.; PALMER, T.; MILlIGAN, G.; HOUSLAY, M.D. Alterations in G-protein expression and the hormonal regulation to adenylate cyclase in the adipocytes of obese (fa/fa) Zucker rats. Biochemical Journal, v.276, p.197-202, 1991.

STRICKER, P. \& GRUETER, F. Action du lobe anterieur de l'hypophyse sur la montee laiteuse. Comptes Rendus v.99, p.1978-1980, 1928.

SUN, H.; SEYER, J. M.; PATEL, T. B. A Region in the Cytosolic Domain of the Epidermal Growth Factor Receptor Antithetically Regulates the Stimulatory and Inhibitory Guannine Nucleotide-Binding Regulatory Protein of Adenylyl cyclase. Proceedings National Academy of Science USA, v.92, p.2229$223,1995$.

SUNAHARA, R. K.; DESSAUER, C. W.; GILMAN, A. G. Complexity adn diversity of mammalian adenylyl cyclases. Annu. Rev. Pharmacol. Toxicol., v.36, p.461-480, 1996. 
SUSA M. Heterotrimeric G proteins as fluoride targets in bone (Review). International Journal of Molecular Medicine, v.3, $\mathrm{n}^{\circ}$ 2, p. 115-126, 1999.

SZTALRYD, C. \& KRAEMER, F.B. Differences in hormone-sensitive lipase during fasting. American Journal of Physiology, v.266, p.179-185, 1994.

TAUSSIG, R. \& GILMAN, A.G. Mammalian membrane-bound adenylyl cyclases. The Journal of Biological Chemistry, v.270, no 1 , issue 6, p.1-4, 1995.

TESMER, J. J.; SUNAHARA, R. K.; GILMAN, A. G.; SPRANG, S. R. Crystal Structure of the Catalytic Domains of Adenylyl Cyclase in a Complex with Gs·GTPS. Science, v.278, p.1907-1916, 1997.

THOMPSON, S.H.; BOXHORN, L.K.; KONG W.; ALLEN, R.E. Trenbolone alters the responsiveness of skeletal muscle satellite cells to fibroblast growth factor and insulin like growth factor. Endocrinology, v.124, p.2110-2117, 1987.

TSAI, S.J. \& WILTBANK, M.C. Quantification of mRNA using competitive RT-PCR with standart-curve methodology. Biotechniques, v.21, p.862-866, 1996.

TUGGLE, C.K. \& TRENKLE, A. Control of growth hormone synthesis. Domestic Animal Endocrinology, v.13 (1), p.1-33, 1995.

ULlRICH, A.; GRAY, A.; TAM AW, Y-F. T.; TSUBOKAWA, M.; COLLINS, C.; HENZEL, W.; LEBOM, T.; KATHURIA, S.; CHEN, E. Insulin-like growth factor I receptor primary structure: comparison with insulin receptor suggests structural determinants that define functional specificity. EMBO Journal, v. 5, p. 2503-2512, 1986.

VAUGHAN, M. The production and release of glycerol by adipose tissue incubated in vitro. The Joumal of Biological Chemistry, v.237, issue 11, p.3354-3358, 1962.

VAUGHAN, M.; BERGER, J.A.; STEINBERG, D. Hormone-sensitive lipase and Monoglyceride lipase activities in adipose tissue. Joumal of Biological Chemistry, v.239, p.401-409, 1964.

VERNON, R.G.; FINLEY, E.; FLINT, D.J. Role of growth hormone in the adaptations of lipolysis in rat adipocytes during recovery from lactation. Biochemical Journal, v.242, p.931-934, 1987.

VERNON, R.G. \& FINLEY, DE. Roles of insulin and growth hormone in the adaptations of fatty acid synthesis in white adipose tissue during the lactation cycle in sheep. Biochemical Journal, v.256, p.873-878, 1988.

VERNON, R.G.; FINLEY, E.; WATT, P.W. Adenosine and the control of adrenergic regulation of adipose tissue lipolysis during lactation. Journal of Dairy Science, v.74, p.695-705, 1991.

VERNON, R.G.; PIPEROVA, L.; WATT, P.W.; FINLEY, E.; LINDSAY-WATT, S. Mechanisms invloved in the adaptations of the adipocyte adrenergic signal-transduction system and their modulation by growth hormone during the lactation cycle in the rat. Biochemical Journal, v.289, p.845-851, 1993.

WAHRENBERG, H.; BOLINDER, J; ARNER, P. Adrenergic regulation of lipolysis in human fat cells during exercise. European Journal of Clinical Investigation, v.21, p.534-541, 1991.

WANG, S.M.\& FONG T.H. ALipid Droplet-Specific Capsule Is Present in Rat Adrenal-Cells: Evidence from a Monoclonal Antibody. Biochem. Biophus. Res. Commun., v. 217, n.1, pp.81-88, 1995.

WATT, P.W.; FINLEY, E.; CORK, S.; CLEGG, R.A.; VERNON, R.G. Chronic control of the $\beta$ - and $\alpha 2-$ adrenergic system of sheep adipose tissue by growth hormone and insulin. Biochemica Journal, v.273, p.39$42,1991$. 
WEDWGAERTNER, P.B.; WILSON, P.T.; BOURNE, H.R. Lipid moficiations of trimeric G proteins. The Journal of Biological Chemistry, v.270, n², p.503-506, 1995.

WERTHEIMER, E. \& SHAPIRO, B. The physiology of adipose tissue. Physiological Reviews, v.28, p.451464, 1948.

WHITE, M. F. \& KAHN, C. R. The insulin signaling system. The Journal of Biological Chemistry, v. 269, p. 1-4, 1994.

WILKIE, T.M.; CHEN, Y.; GILBERT, D.J.; MOORE, K.J.; YU, L.; SIMON, M.I.; COPELAND, N.G.; JENKINS, N.A. Identification, chromosomal location, and genome organization of mammalian Gprotein-coupled receptors. Genomics, v. 18, n² 2, p.175-84, 1993.

WILSON, B.E.; DEEB, S.; FLORANT, G.L. Seasonal changes in hormone-sensitive and lipoprotein lipase mRNA concentrations in marmot white adipose tissue. American Journal of Physiolology, v.262, p. 177$181,1992$.

WONG, S.K.F. \& ROSS, E.M. Chimeric muscarinic cholinergic $\beta$-adrenergic receptors that are functionally promiscuous among G proteins. The Journal of Biological Chemistry, v.269, p.18968-18976, 1994.

YAMAMURA, H.; LAD, S.P.M.; RODBELL, M. GTP stimulate and inhibits adenylate cyclase in rat membranes throught distinct regulatory processes. The journal of Biological Chemistry, v.252, $\mathrm{n}^{\circ} 22$, p.7364-7366, 1977.

YAN, S.Z.; HUANG, Z.H.; RAO, V.D.; HURLEY, J.H.;TANG, W.J. Three Discrete Regions of Mammalian Adenylyl Cyclase Form a Site for Gs ActivationThe American Society for Biochemistry and Molecular Biology, v.272, n 30, p. 18849-18854, 1997.

YANG, Y.T. \& BALDWIN, R. L. Lipolysis in isolated cow adipose cells? Journal of Dairy Science v.56, p.366-374, 1973.

YEAMAN, S.J. Hormone-sensitive lipase- a multipurpose enzyme in lipid metabolism. Biochimica at Biophysica Acta, v.1052, p.128-132, 1990.

YIP, R.G.C. \& GOODMAN, H.M. Growth hormone and dexametasone stimulate lipolysis and activate adenylyl cyclase in rat adipocytes by selectively shifting $\mathrm{Gi}$ alfa2 to lower density membrane fractions. Endocrinology, v.140, p.1219-1227, 1999.

YOUNG, F. G. Experimental stimulation (galactopoiesis) of lactation. Br. Med. Bull, v.5, p. 155-160, 1947.

ZHANG, J. \& BYRNE, C.D. Differential priming of RNA templates during cDNA synthesis markedly affects both accuracy and reproducibility of quantitative competitive reverse-transcriptase PCR. Biochemical Journal, v.337, p.231-241, 1999.

ZHANG, Y.; PROENCA, R.; MAFFEI, M. et al. Positional cloning of the mouse obese gene and its human homologue. Nature, v.372, n.6505, p.425-432, 1994.

ZHOU, L.; CHEN, H.; LIN, C. H.; CONG, L. N.; MCGIBBON, M. A.; SCIACCHITANO, S.; LESNIAK, M. A.; QUON, M. J.; TAYLOR, S. I. Insulin Receptor Substrate-2 (IRS-2) Can Mediate the Action of Insulin to Stimulate Translocation of GLUT4 to the Cell Surface in Rat Adipose Cells. The Journal of Biological Chemistry, v.272, p.29829-29833, 1997.

ZIMMERMANN, G.; ZHOU, D.; TAUSSIG, R. Genetic Selection of Mammalian Adenylyl Cyclase Insensitive to Stimulation by G $\alpha$. The Journal of Biological Chemistry, vol.273, p.6968-6975, 1998. 


\section{APÊNDICE A}

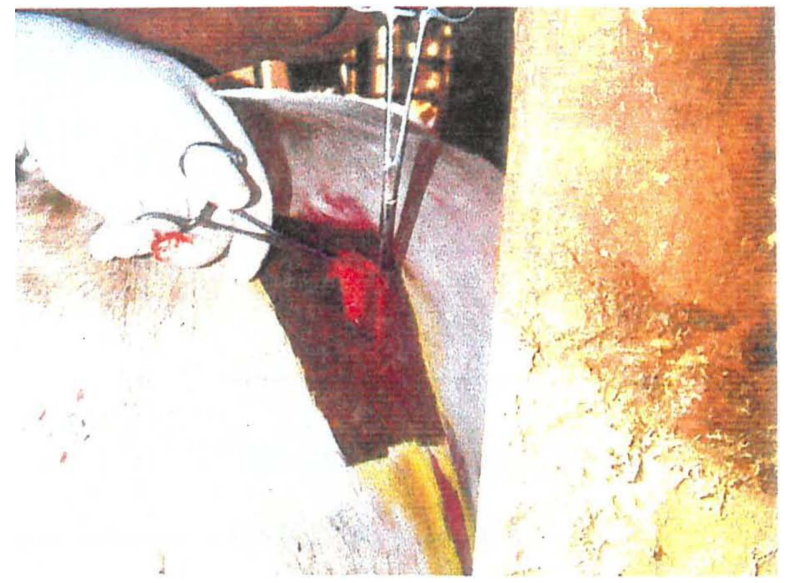

Figura 13- Visualização de uma biópsia realizada em um dos animais do experimento.

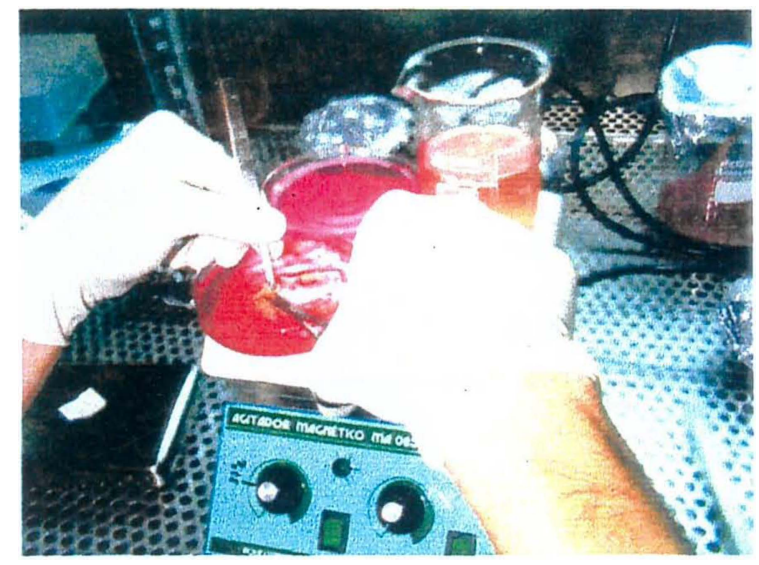

Figura 14- Visualização da preparação dos explantes de tecido adiposo para a cultura de tecidos.

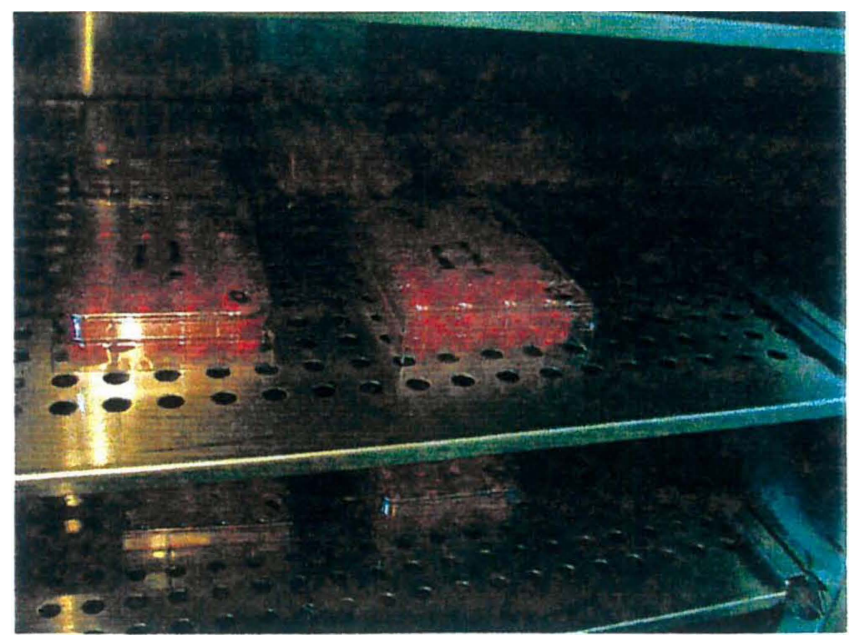

Figura 15- Visualização da estufa de incubação e placas de cultura de tecido com 24 poços. 


\section{APÊNDICE B}

Meio 199

\begin{tabular}{ccc}
\hline & Sem bST & Com bST \\
Médias & 0,059 & 0,066 \\
Desvio Padrão & 0,048 & 0,035 \\
\hline
\end{tabular}

Tabela 10. Liberação de NEFA no meio 199 após 24 horas de cultura de tecido adiposo de bovinos

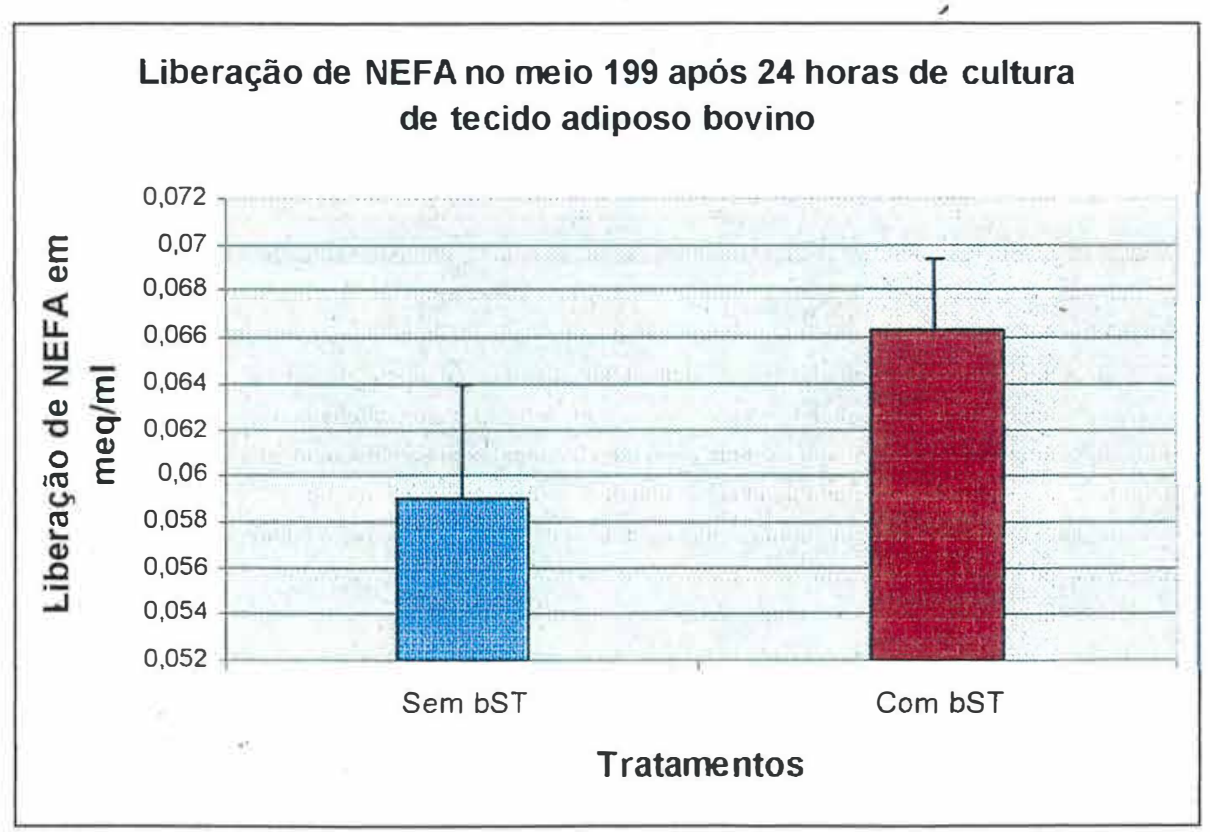

